University of Louisville

ThinkIR: The University of Louisville's Institutional Repository

Electronic Theses and Dissertations

$5-2017$

\title{
American emergency : catastrophe and culture in the U.S.A., from the Civil War to Hurricane Katrina.
}

Lynda Kristian Mercer

University of Louisville

Follow this and additional works at: https://ir.library.louisville.edu/etd

Part of the American Studies Commons

\section{Recommended Citation}

Mercer, Lynda Kristian, "American emergency : catastrophe and culture in the U.S.A., from the Civil War to Hurricane Katrina." (2017). Electronic Theses and Dissertations. Paper 2633.

https://doi.org/10.18297/etd/2633

This Doctoral Dissertation is brought to you for free and open access by ThinkIR: The University of Louisville's Institutional Repository. It has been accepted for inclusion in Electronic Theses and Dissertations by an authorized administrator of ThinkIR: The University of Louisville's Institutional Repository. This title appears here courtesy of the author, who has retained all other copyrights. For more information, please contact thinkir@louisville.edu. 


\title{
AMERICAN EMERGENCY: CATASTROPHE AND CULTURE IN THE U.S.A., FROM THE CIVIL WAR TO HURRICANE KATRINA
}

\author{
By \\ Lynda Kristian Mercer \\ B.A., University of Louisville, 2005 \\ M.A., University of Louisville, 2007

\begin{abstract}
A Dissertation
Submitted to the Faculty of the

College of Arts and Sciences of the University of Louisville in Partial Fulfillment of the Requirements

for the Degree of
\end{abstract} \\ Doctor of Philosophy \\ in Humanities \\ Department of Humanities \\ University of Louisville \\ Louisville, Kentucky
}

May 2017 



\title{
AMERICAN EMERGENCY: CATASTROPHE AND CULTURE IN THE U.S.A., FROM THE CIVIL WAR TO HURRICANE KATRINA
}

\author{
By \\ Lynda Kristian Mercer \\ B.A., University of Louisville, 2005 \\ M.A., University of Louisville, 2007
}

A Dissertation Approved on

April 24, 2017

By the following Dissertation Committee:

Director, Dr. Susan Ryan

Co-Director, Dr. Aaron Jaffe

Dr. Simona Bertacco

Dr. Judith Roof 


\section{DEDICATION}

This dissertation is dedicated to my best friends - my family.

To my parents, Rebecca Mercer and Stanley Hensley; to my big sister Sabrina and my little brother Troy: the most unusual and enchanting people I have ever met.

To my Aunt Annabell Zachery, a kindred spirit and inspiration, you lived unapologetically by your own set of rules and you taught me what happiness looks like. I

really wish you were here. To my Aunt Lisa, whose gentle care for others has served as a model of love and strength.

And to my Grandma and Grandpa, Gladys and John L. Mercer, who took such perfect care of me.

Thank you all for being part of me. 


\section{ACKNOWLEDGMENTS}

I would like to thank the members of my committee for their generosity and insight as I worked to put together the many pieces of this project. Dr. Aaron Jaffe, as co-

director, has been instrumental in helping me to be a better scholar, and his willingness to work with so many of my ideas has made this research exciting and fun. The friendliness and guidance that he and his wife, Dr. Tatjana Soldat-Jaffe have extended to me over the years has made my time working on this project all the more valuable. Dr. Susan Ryan's co-directorship has also played a big part in showing me how to shape and connect ideas, and her expertise and attention has improved my scholarship in countless ways. Her service to me as a scholar has been a gift. Dr. Simona Bertacco has given me muchappreciated warmth and encouragement. Her feedback has generated intersections of new and immeasurably useful scholarship for me, and I am glad I had someone with so much rich perspective on this committee. She has been a source of encouragement at every level since I began this research, and I am grateful to her even more, knowing how many others she serves every day in her role as a Professor and as Director of the Humanities Ph.D. program. My Outside Reader, Dr. Judith Roof was critical in incredibly helpful ways. She engaged my work with thoughtful respect and guidance as she pushed me to refine my points and build clearer arguments. Her insights have significantly improved my development even in the short time I have known her. Her generosity and approachability has been an unexpected bonus in this endeavor.

The Humanities Ph.D. program and the Humanities Department have given me a lot. In particular, Lisa Schonburg has absolutely been the strongest link in the chain that makes our program a wonder of interconnected parts that somehow works smoothly. She manages, troubleshoots, communicates, and researches anything and everything that needs attention, no matter how minor. I am so grateful for her competence and help through the years. Dr. Annette Allen championed my instincts as a student and helped me to find outlets for my creative abilities that I would never have recognized without her. 
Professor Elaine Wise has been thoughtful and attentive to me in many ways, and if it were not for her, I would never have had the unique and enviable teaching opportunities that I have had. Shari Gater, Lisa Shugoll, Brandon Harwood, and Justy Engle have been friends in the department who have made the space better just by being there.

My ideas were influenced by several Literature Professors who introduced me to innovative and fun ways to interact with texts. Dr. David Anderson and Dr. Karen Chandler from U of L's English Department were two of the most intellectually stimulating and genuinely kind Professors I ever had. Dr. Glynis Ridley and Dr. Susan Griffin also made my experiences in graduate school rewarding; they both provided the tools for some of my favorite ongoing research topics in eighteenth and nineteenth century literature, and I enjoyed every minute of the work I did in their courses. Unexpectedly, a course on Shakespeare that I took early in my graduate career, taught by Dr. Julia Dietrich, changed my research fundamentally and introduced entirely new approaches to interpretation and writing in academic and in creative realms.

I am so thankful that my best friends and family have been part of this process with me for so long. I have needed undue attention, and having someone to listen as I processed my ideas has made the difference in my writing and thought. I think my completion of this project has made the people close to me happier than it has made me. My best friends, Emerald Feland, Stephanie Koenig, Travis Gault, Mary Margaret Trinkle, Georgette Covert, Natasha Montague, Jeremy Garrett, and Levity Tomkinson have been an extended family. Having a group of loud, irreverent, and unfathomably caring friends to support me has kept me optimistic and happy, even in the most challenging times of my life and graduate career.

Adam Robinson's friendship to me since our undergraduate years is a gift I could never repay. He has made me a much better person and helped me find my path in life, and I am grateful to know him. Larry Robinson, Sr. and Lynn Robinson are two of the most accepting and humble people I know, and they have made my world a lot warmer. I am honored to call them my friends. I will be forever grateful to Coach Haak and Phillip Woosley for taking the time to mentor me during the formative years of my youth and young adulthood. I will always be grateful for the efforts they put forth in pushing me to recognize my own value and put myself out into the world. Joyce Basil and Stephi Wolff 
also gave me support and unconditional love during turbulent times, showing me the nitty-gritty of how to grow up and focus on what really matters. Their care and patience with me has enabled me to do and give more in every area of my adult life.

My brother and sister have given me hope, acceptance, lightness, honesty, and loyalty. I have long said that in the midst of everything bad that ever happened, I always knew I had them. That is the biggest blessing of my life. They have been companions since day one and are the two people who know me best and who support me with the kind of tough love that only a sibling can give. If all else fails and I get bogged down in my own neuroses, I know they will find a way to make me laugh at my own absurdity (or someone else's). My parents have given me more than they should, and I'm so happy that they get to celebrate this accomplishment with me. They are the most delightfully delusional dreamers a kid could hope to call parents. I was lucky to have adults around me who treated me with respect and camaraderie, who let me make my own decisions and face my own consequences. From my youngest childhood years, I have gotten to explore everything I wanted to explore, with no judgments or directives, no lofty expectations to uphold, no fear of failure or disappointment — a dizzying and truly fun childhood characterized by curiosity as a virtue unto itself. I could not ask for a more generous cohort or better champions than these four people have been and continue to be.

My very closest friend and partner, Dr. Steven Watkins has kept me moving forward as I worked on this project, and has shown me what discipline and depth means. I am lucky to have him in my life - a truly open-minded and sincere human being. Having someone like him tell me that he admires me has made me rethink my adage that I don't want to be part of any club that would have me as a member. He is the Zissou, and I am a proud member of the Zissou Society. Adventures await.

The life I am so grateful to get to live, and the career that I have had as a student has been possible only because I had Gladys and John Mercer as grandparents and surrogate parents. They nurtured me. I have never felt at home anywhere like I did with them, and nothing has really been quite as good as it was when they were here. Every day, they taught me how much beauty, love, and intelligence lives in the world around me, and not a thought in my head will ever exist that didn't pass through them first. 


\section{ABSTRACT \\ AMERICAN EMERGENCY: CATASTROPHE AND CULTURE IN THE U.S.A., FROM THE CIVIL WAR TO HURRICANE KATRINA \\ Lynda Kristian Mercer}

April 24, 2017

This dissertation examines socio-cultural experiences of national disasters in the United States as they intersect with political rhetorics of democracy, to understand the forms and functions of state power as it is mediated through famous historical figures. Tracing the manifold possibilities from within and around the disruptive spacetimes of disaster, which sociologist Harvey Molotch describes in their ultimate function as societal "rationalizers" (371), I analyze catastrophes as contested spaces and histories that often get situated as variations on the "man vs. nature/god/man" binaries in public discourse. By analyzing the deployment of, and response to, such explanatory frameworks in the United States since the nineteenth century, this project complicates and exposes processes of power and transgression as they relate to democracy and capitalism.

This project is divided into three chapters, to formulate a partial sketch of the modern historical trajectory of the nation as it has navigated into and out of catastropheeach chapter dealing with a distinct disaster that resulted in large-scale public casualties that were broadcast nationally (and in most cases globally), and which dramatically altered the composition of land and the populations who inhabited it: The Civil War, The Dust Bowl, and Hurricane Katrina. Roughly 70 years spans the gaps between each of the 
three catastrophes, and each chapter analyzes not just historical events of the disasters themselves, but the political and cultural environments of these phenomena as they affected spatio-temporal features of society and history before and after they occurred. To explicate these relationships and to further interrogate the ways in which the markers of race and gender have figured within these dynamics and as they continue to figure today, I include contemporary sites of excavation through analysis of present-day film and television productions as they reify particular components of disaster, biopower, and capitalism as distinctly "American" democracies. I deploy these interpretations in ways that speak to historical and fictional representations of American civilization(s) but to speak as well to elements within the larger constellation of connections in this project and produce additional perspectives on ideas like citizenship, progress, democracy, and power as they have been reformulated in popular discourse. 


\section{TABLE OF CONTENTS}

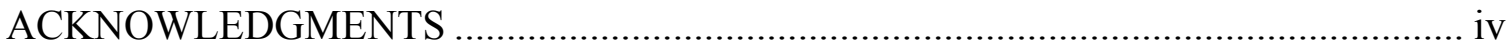

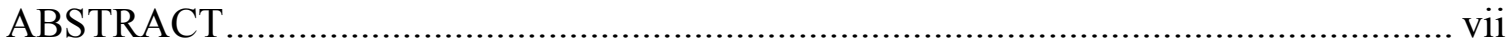

1. INTRODUCTION: CATASTROPHE LESSONS ................................................

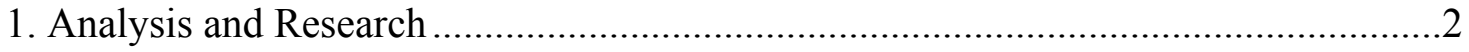

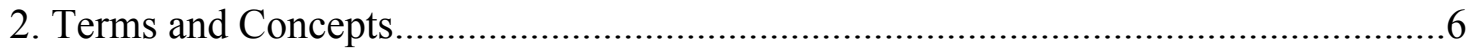

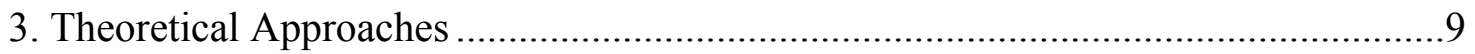

2. CHAPTER ONE: BURYING BODIES: CIVILIZATION AND CITIZENSHIP

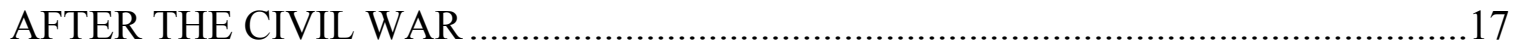

1. Rooting the Republic: Beautiful Burial and the Advance of Civilization .................19

2. Bad Deaths: Civil War and the Decivilizing of America ......................................23

3. Burying (Some)Bodies: Gettysburg and the Future of the Republic ........................30

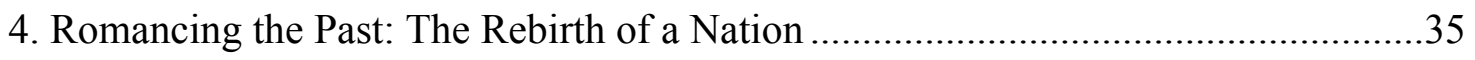

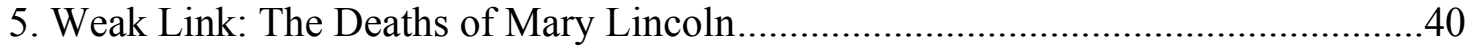

6. The "Better Angels of Our Nature": Varina Davis's Old South.............................48

7. "People Like to Believe in Fairy Tales": Jackie Curates Camelot ..........................55

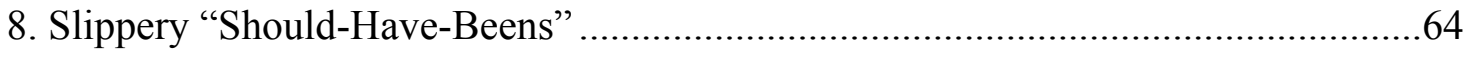

3. CHAPTER TWO: FRONTIER FUTURES: PROGRESS, PURITY, AND PENANCE

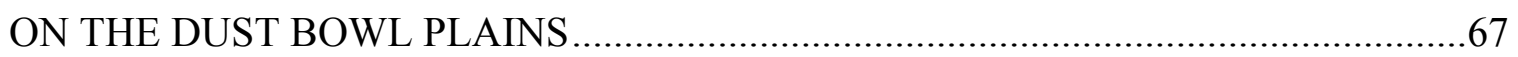

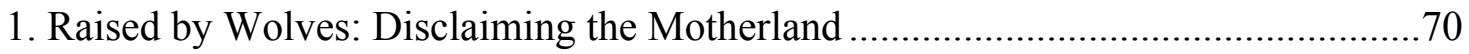

2. New World" History: Mapping the Origin of the American Man............................73

3. Heterotopic History: Telling and Selling American Progress ...............................79

4. Might is Right: Teddy Roosevelt as American Archetype ....................................81

5. Filling the Field: The Early Art of American Empire-Building ............................90

6. Dust Bowl: The Great American Desert of the Real .............................................93 
7. Tilling the Field: The Unsettling of God's Country .............................................98

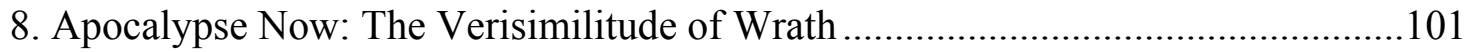

9. Frontier Faith and Filth: How to Pray the Dirt Away ..........................................110

10. The Dirty Thirties Redeemed: Interstellar Rewrites the Future..........................113

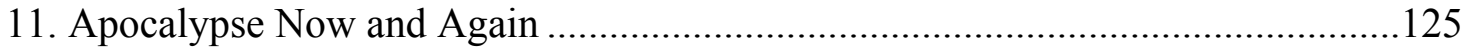

4. CHAPTER THREE: RUINS OF KATRINA: INVISIBILITY, CONTROL, AND THE

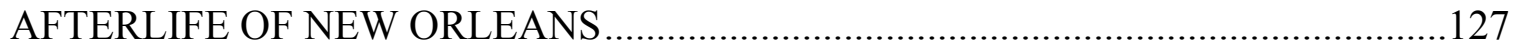

1. Colonial Confusion: Authority, Agency, and Color Lines in New Orleans ............130

2. Voodoo Queen: Conjuring Power from the Margins...........................................135

3. Sacred Spaces and Suspect Spirits: Paying Homage in the City of the Dead .........142

4. Biopolitical New Orleans: The All-American Host ............................................147

5. Neoliberal Norms: Democracy, Totalitarianism, and The Emergency ..................155

6. Left to Die: Surplus Populations, Relief, and "Deservingness" ............................161

7. Cornrow City vs. The French Quarter: Marie Laveau as Black Nemesis ...............169

8. The Queen is Dead, Long Live the Queen........................................................176

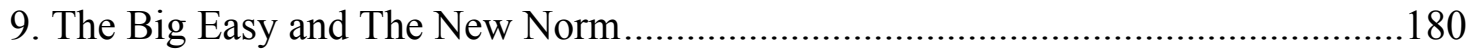

5. CONCLUSION: TIME, SPACE, AND NOT-SO-FINAL FRONTIERS ..................183

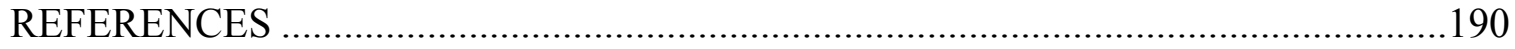

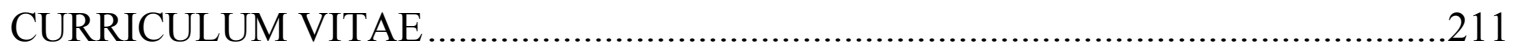




\title{
INTRODUCTION
}

\section{CATASTROPHE LESSONS}

\begin{abstract}
"Appeals to mythologies of place, person and tradition, to the aesthetic sense, have played a vital role in geopolitical history. Herein, I think, lies the significance of conjoining aesthetic with social theoretic perspectives, bringing together understandings that give space priority over time with those that give time priority over space." (Harvey, "Between Space and Time" 430)
\end{abstract}

This dissertation examines socio-cultural experiences of national disasters in the United States as they intersect with political rhetorics of democracy, to understand the forms and functions of state power as it is mediated through famous historical figures. Using three major American catastrophes as sites of excavation into the topography of civilization and citizenship in the United States, my research illuminates constellations of geo-historical trajectories for the nation as it has navigated into and out of domestic catastrophes. This project shows why the framework of catastrophe is a useful mode of inquiry for American cultural studies. Tracing the manifold possibilities from within and around the disruptive spacetimes of disaster, which sociologist Harvey Molotch describes in their ultimate function as societal "rationalizers" (371), I analyze disasters as contested spaces and histories that often get situated as variations of the "man vs. nature/god/man" binaries in public discourse. By analyzing the deployment of, and response to, such explanatory frameworks in the United States since the nineteenth century, this project 
complicates and exposes processes of power and transgression as they relate to democracy and capitalism.

As the state of emergency has become a crucial element of the governmentality of biopower, the use of disaster as a "rationalizer" is growing increasingly obvious and its performances less convincing. My research and analysis is concerned with the workings of biopower and its relationship to neoliberalism in the U.S., and I interrogate this relationship and its implications through what, for lack of a formal term, I might call a "disaster-centric" approach. In privileging the unique material conditions of catastrophes as the framework for my project, I hope to yield insight into the negotiations that take place between ideological and material realms of democracy as they have moved across the landscape of modern American civilization.

\section{Analysis and Research}

This project is divided into three chapters, to formulate a partial sketch of the modern historical trajectory of the nation as it has navigated into and out of catastropheeach chapter dealing with a distinct disaster that resulted in large-scale public casualties that were broadcast nationally (and in most cases globally), and which dramatically altered the composition of land and the populations who inhabited it: The Civil War, The Dust Bowl, and Hurricane Katrina. Roughly 70 years spans the gaps between each of the three catastrophes, and each chapter analyzes not just historical events of the disasters themselves, but the political and cultural environments as they affected spatio-temporal features of society and history before and after these disasters. While all three of the disasters that I examine in this dissertation have been the subjects of innumerable scholarly treatments, my decision to unite them as a constellation is hinged upon 
conceptual features related to American citizenship that each of these brings to light in the others when juxtaposed as part of this larger undertaking.

The disasters of this project resemble to one another in their ability to generate new understandings of the spatialized approach to democratic participation in the United States. The title of this project, "American Emergency," speaks to the role of "emergency," understood in ontological, juridical, cultural, and psychological terms as it has affected social dynamics apart from, and through, the three major catastrophes that I discuss. Crucially, as the Civil War generated massive death and destruction, the tyranny of the urgent in the movement of soldiers across land profoundly disrupted the spatial sensibilities of Americans whose fellow citizens were left behind on the battlefields. When the pace of the war could not keep up with its own production and unburied bodies began to create a spectacle of savagery that belied exceptionalist rhetoric of America as a great civilization, national preoccupation with memorial and memory became the manner by which many traumatized citizens reconciled themselves to the devastating toll of the conflict.

The public reception of First Ladies of the Civil War, Mary Todd Lincoln and Varina Davis, exemplifies the work of this memorializing impulse and its consequences for society and for democracy in the U.S. Very little side-by-side analysis of these two women has been done to date, and in discussing the two famous widows, I connect the role of Civil War mourning in the U.S. to a larger analysis of space, spectacle, and democratic citizenship. Mary Todd Lincoln's son had her committed to an insane asylum because of her socially inappropriate emotional candor, but beyond this well-known anecdote is a story of cultural anxiety and collective mourning as figured through Varina 
Davis's mythological role as widow and figurehead of a great, but tragically defeated "Lost Cause" civilization.

While the Civil War represents a complicated story of memorializing, historicizing, and forgetting for a young nation as it processed the consequences of what could be thought of as the ultimate "man-made" disaster—war against oneself—an analysis of the Dust Bowl allows for a study of modern American representations of the "man vs. nature" binary and the effects and affects of this construction for the citizens of the Plains states as "man vs. nature" shifted into an apocalyptic reckoning of "man vs. god" in popular rhetoric. The epic disaster that hit the farmers of the plains in the 1930s was undeniably the result of human intervention, yet it reflected deliberate choices on the part of the federal government and capitalist enterprises about how the population should inhabit its newly acquired land holdings. The spatial politics of democracy as conquest are figured, even today, in imagery of the frontier and frontiersman, and by analyzing Progressive Era rhetoric and frontier mythology alongside the subsequent disaster of the Dust Bowl that resulted from settlement and over-cultivation of the Plains, I posit this catastrophe as a site for analyzing apocalypse as an ongoing disaster of American capitalism.

A study of New Orleans after Hurricane Katrina provides a synthesis of many of the themes that arise in the discussions of the Civil War and the Dust Bowl, and it further complicates, illuminates, and raises new questions about progress, geographical development, and democratic citizenship in the neoliberal nation. Interrogating the sociocultural processes of freedom and power as they were enacted in the racial dynamics of early New Orleans and as they changed throughout the nineteenth and twentieth 
centuries, we can examine the forces of biopower in the crisis that Hurricane Katrina exposed in New Orleans. The invisible authority of biopolitical control has functioned historically in ways that have allowed transgressive power to exist from the margins, in spite of juridical processes of control that reduced humans to bare life as "property," but neoliberal capitalist policies have expanded the commoditizing processes of biopower and now treats those same populations as "disposable" (Giroux 172). Exploring postKatrina New Orleans, we encounter multi-layered narratives of competing claims to historical visibility, agency, and survival that had been prevalent in the city as a site of "exotic" transgressive empowerment and marginalization long before the disaster, and which implicated similar social dynamics along raced and gendered class lines throughout the nation.

The organization of this project is chronological, but the ideas I explore are situated outside traditional spatio-temporal confines. To illuminate these relationships and to further interrogate the ways in which raced and gendered representatives have figured within these dynamics and as they continue to figure today, I include contemporary sites of excavation through analysis of present-day film and television productions that reify particular components of disaster, biopower, and capitalism as distinctly "American" democracies. I deploy these interpretations in ways that speak to historical and fictional representations of American civilization(s) but to speak also to elements within larger constellations of connections in this project, and to produce additional perspectives on ideas like citizenship, progress, democracy, and power as they have been reformulated in postmodern popular discourse. 


\section{Terms and Concepts}

This project inserts itself into a multi-disciplinary conversation about national space making and power relations in the United States. My aim is to build upon the ideas of thinkers in the realms of cultural studies and American studies, as well as to show the potential of catastrophes as interpretive spaces for new applications and ideas within the humanities. The field of Disaster Studies originated through traditional quantitatively oriented "disaster response" methods of sociologists, geographers, and scientists (Lindell 813-4), but the field (like many others across the academy) has begun to expand its scope and scale in social science arenas (Tierney, "From Margins" 523). As the massive and ongoing multi-disciplinary responses to Hurricane Katrina shows, catastrophes have the potential to generate intellectual discourses that enliven already-existing conversations (like Foucault's concept of biopower) and invite new perspectives and intellectual partnerships to engage in original conversations (such as the multi-disciplinary, multivolume Katrina Bookshelf series, spearheaded by sociologist Kai Erikson, along with a collective of academic and non-academic researchers [Erikson, "Studying Katrina" 350]). This project aims for a cultural critical analysis of how American constructions of exceptional nationhood are continually impacted by the global and individual consequences of their own productions.

Disaster historian Kevin Rozario’s definition of modernity corresponds with mine, defined by certain overarching themes, such as: "a 'rational' and scientific endeavor to improve life on earth [and] a dynamic system of spatial reorganization and capital accumulation (creative destruction)" (14). Where relevant, I try in this project to indicate the significance of early imperial expeditions as they impacted colonial 
occupation in the "new world," and in subsequent manifestations of European conquest. The overall scope of this project, however, utilizes the terms "modern" and "modernity" to refer to the period in late modernity that roughly corresponds with the eighteenth century Enlightenment Era through today. The popular influence of ideas throughout this time about the importance of science and rationality, public discourse and literacy, individual freedoms, and marked shifts in global commerce, as well as the rise of industrial capitalism, provide a meaningful foundation for contextualizing the trends that have driven politics, culture, society, aesthetics, and commerce up to today (though I recognize that characterizing the Enlightenment as the sole influence on modern western society would be grossly inadequate).

I employ the phrase "postmodern" or "postmodernity" to illustrate ideas that emphasize the role of fetishized, commoditized mediations and images as they have impacted popular expectations for various experiences of western societies (as in New Orleans' revamping of its tourist industry to reflect the Disney version of New Orleans, which was itself based on a simplistic imagining of antebellum New Orleans). David Harvey divines the economic market shift from Fordism to flexible accumulation as a useful illustration for understanding the emergence of postmodern conditions, focusing on the market factors that have led to a "space-time compression," wherein our experiences of both space and time have been compacted and sped up. Similar to Baudrillard's discussion of speed and the velocity of history in the U.S. in America, Harvey describes the influence of such postmodern economies in mainstream American life. The major effect of the postmodern time-space compression and economic environment that fostered it is that we have now functionally utilized aesthetics as a 
replacement for ethics, and global capitalism has become the controlling force of human society (The Conditon of Postmodernity 87).

My analysis of the United States does not treat the nation in isolation and is acutely aware of the globalized world in which the United States was produced and with which it is essentially inseparable. In fact, a primary aim of this project relates the ideology of American representative democracy and its spatialized framing to its transatlantic histories, which necessarily includes discussions of the global slave trade, imperial conquest, and European Enlightenment ideals. I am also aware that there are multiple Americas and that my use of the word "America" to refer specifically to the United States does not accurately delineate this distinction, and that this usage may be viewed as problematic. This is a conscious effort on my part to reflect this project's goal of explicating illusory mechanisms of political rhetoric (such as the use of "America" as a synonym for the U.S. as it currently operates in popular culture in the United States) that define the nation as a great civilization, as if the "America" of the United States encompasses all Americas, or as if the United States models nationhood for the whole of the North and South American continents.

Underlying this inquiry into state power as it has manifested through the rhetorics of democracy is my concern about the development of power structures as they operate across western democratic societies generally. I recognize that currently as a military, economic, and cultural hegemony, the disasters and economic uses of disasters in the United States disproportionately affect global power structures and impact civilizations and societies worldwide, though man-made and natural disasters of far greater frequency, 
size, and strength occur in other areas of the world, often with considerably less mainstream attention.

\section{Theoretical Approaches}

Working with Foucauldian critical-historical analyses of state power that analyze its forms and functions throughout the nineteenth and twentieth centuries and which offer useful frameworks for understanding tools of state power as they have manifested through today, this project views democracy and citizenship as fluid processes. My approach to the rhetorical constructions of "democracy" treats it as a concept with shifting values and meanings. Similarly, I interpret the role of history and historicism in the rhetoric of democracy in the modern U.S. with a theoretical lens that emphasizes the public sphere as a biopolitical arena, increasingly employed as a tool under the auspices of the state, and through the state of emergency.

Foucault outlines the rise of biopower in western society that came about, in part, through the institutionalization of discipline as a practice of self-control. Self-control generates docility to a society's various and often imperceptible processes of national subjectivity. Under a biopolitical regime, control relies upon a system in which the vast majority of subjects willingly participate in their own discipline in countless ways on a daily basis, where "biological existence [i]s reflected in political existence" (Foucault Society 143). His explication of biopower as the "calculated management of life" (140) relates to similar ideas in Norbert Elias's notion of "civilizing processes" as they developed in western societies during the eighteenth and nineteenth centuries, and my project is informed by these intersecting understandings of affect, discipline, and reason as underpinnings in the framework of state power. Benedict Anderson's siting of 
nationalism as it arose in the eighteenth century with the advent of print culture and its facilitation of "imagined communities" of national subjects also informs my analysis of democracy and citizenship in the United States, especially as it was rhetorically constructed in the memorializing discourses of antebellum rural cemeteries, post-bellum national cemeteries, and Civil War monuments.

Similar themes of passivity and imagined communities are at work in Russ Castronovo's Marxian critique of the rhetoric of nineteenth century American democracy as universalizing and pacifying discourses that constitute what he calls "necro ideological" constructions. I consider these necro ideologies as precursors to, or examples of the growth of different forms of biopolitical docility in the citizenry into the present day, notably in the New Orleans tourist industry. Castronovo's ideas, along with the theoretical concepts outlined by Elias and Anderson provide a socio-historical framework for thinking about American democracy, and I join them with Lauren Berlant's queer theoretical understandings of affect, citizenship, and democracy. Berlant's perspectives on intersubjectivity as an alternative framework to the "cruel optimism" of modern American citizenship focuses on the sociological and psychological consequences of using representative figures (like celebrities and politicians) as surrogates for democratic wholeness and ideological harmony.

Admittedly, elements of the theoretical ideas I deploy throughout this project will generate and reveal aporias and contradictions. For instance, the "bare life" proposed by Agamben - which I utilize alongside a biopolitical understanding of the events of Katrina, in particular-liberally alters elements of Foucault's biopolitical to fit its framework through what Claire Blencowe points out is a conflation of biopower as it was 
produced by nineteenth century medical and social institutions and sovereignty as expressed through the ancient ban (117). ${ }^{1}$ Moreover, and perhaps more importantly, as Blencowe notes, Agamben extends biopower by misrepresenting Foucault's perspectives on the biological as a political category with an inherently negative valence in order to make claims about totalitarianism as what would seem to be an almost inevitable outgrowth of biopower (117). Foucault's approach, she asserts, allows for multivalent possibilities within biopower-potential for positive or negative uses within a system that, in spite of its use of power to facilitate innumerable atrocities, has also exerted control in ways that have improved human existence through the growing understanding of populations and the improvements that social contracts can entail for society. Agamben's bare life and sovereign exception, in Blencowe's view, should not assume a connection between neoliberalism and totalitarianism as extensions of biopolitics (123).

While Agamben's linkage of totalitarianism with neoliberal democracy can be argued as a specious connection, I do not see in this problem a certain foreclosure of the possibility for Foucault's biopower to foreshadow the connection between neoliberalism and totalitarianism, as we have seen liberal governments expand their biopolitical governmentality drastically since the 1980s: the War on Drugs prefigured the neverending War on Terror, both resulting in the massive growth of oppressive governmentcorporate regimes (the Prison-Industrial Complex and the Military-Industrial Complex). In addition to the more recent and ongoing revelations about the history of illegal domestic surveillance that has been undertaken by the N.S.A. and the C.I.A., the political

\footnotetext{
${ }^{1}$ Homo Sacer is the name for an exiled person under ancient Roman law, whose protections under law were stripped, meaning that this person could be killed with impunity by anyone. This legal power of the ancient ban, as an exception to the law, reflected the potential of the law to use exception to define ontological status through politics, a precursor to Foucault's biopower.
} 
and governmental implications of the 2010 Citizens United decision in the U.S. Supreme Court, as well as the militarization of state and local police throughout the nation, and the corporate monopolization of the agriculture industry on a global scale, among other things, suggests that the biopolitical ideologies of democracy have been bound up as a matter of course with the neoliberal corporate control of vast swaths of the federal government.

Achille Mbembe's “necropolitics" (unrelated to Castronovo's necro ideology, articulated in his 2001 book of the same name) has also supplied fruitful interventions that have updated the concepts of the biopolitical, adding perspectives into the discourse of biopower and modern state authority that account for the rise of non-state actors. The biopolitical and bare life can apply to a number of conditions that may not operate on the scale and scope of the Nazi death camps, but which nonetheless are reflections of the same mechanisms of ontological control. Mbembe explains plantation slavery as a key example of "biopolitical experimentation," comparing the plantation to the camp in its suspension of the law in the name of exception, marked by the slave's "expulsion from humanity altogether" via the "triple loss" of a “'home,' loss of rights over his or her body, and loss of political status" resulting in/from "absolute domination, natal alienation, and social death" (21). He proposes the term "necropolitical" to describe the non-state power that exists in late modern colonialism in places like South Africa and Gaza, where Foucault's biopolitical framework cannot fully account for the systems, methods, and actors who exert control over populations.

Alexander Weheliye further expands Foucault's articulation of biological race and Agamben's bare life by using a black feminist revisionary framework to locate alternative 
ways to inhabit humanity from abject positions - a key element that he does not believe either theory adequately considers within biopolitical theories. Weheliye's foregrounding of "racializing assemblages" as creations of biopower locates such alternatives when it "insists on the importance of miniscule movements, glimmers of hope, scraps of food, the interrupted dreams of freedom found in those spaces deemed devoid of full human life" (12), as they counter the universalizing and negative function of Nazi death camps and the "muselmänner" as the quintessence of bare life.

The majority of my analysis employs biopower and related theoretical tools that I have outlined, and these largely work in conjunction with one another quite comfortably, although the application of Foucault's and Agamben's works necessitates extension and expansion of their ideas. To this end, while I recognize and acknowledge that Agamben's use of biopower as a foundation for bare life is problematic, this does not impede the usefulness of the state of exception and bare life to examine biopolitical effects, and I utilize both ideas as tools in my own analysis, in the vein of Henry Giroux, who uses both concepts to discuss the marginal black population of New Orleans as a "disposable" surplus population that could not fully participate in the machinery of neoliberal capitalism and thus constituted "waste" in the eyes of the governing authorities (175). Likewise, Lynnell Thomas's discussion of tourism both before and after Katrina convincingly links neoliberal biopolitics to the dehumanizing conditions that resemble bare life for blacks who live and work in the heritage tourism industry who are embedded in the machinery of the biopolitical operations of the power structure, and whose dependence upon the system constitutes a social death not unlike the social death of plantation slavery (751). 
In arranging my inquiry into the function of power as it is deployed through tools like nationhood, democracy, civilization, progress, capitalism, and history (among others), I include catastrophe — as the state of emergency, the language of crisis, the "creative destruction"- as a burgeoning site of exploration into mechanisms of biopolitical control. While the fields of sociology and geography have explicitly explored disaster as a primary area of inquiry for some time, the disaster has figured in humanities and cultural studies scholarship in less specified ways. Theorists of all stripe and disposition take on the historical, political, and spatial concerns of disaster as elements within larger methodologies of power and agency, often as part of larger critiques of capitalism. Certain thinkers like Naomi Klein and Kevin Rozario overtly deal in disaster as it functions in a capitalist "creative destruction," or "disaster capitalism," for instance, although neither of them exclusively researches disaster as a primary site of cultural criticism. Nonetheless, both Klein and Rozario have influenced this project as scholars whose critiques foreground disaster as an illuminating thematic, while cultural geographers David Harvey and Edward Soja, whose approaches, while different from one another and not always in agreement, articulate conditions of uneven geographical development as it has figured in the shift from modern to postmodern capitalist structures.

I am also influenced by the sociological work of Kai Erikson, whose early forays into disaster studies and whose centering of disaster as an element of (and not an anomalous event isolated from) society in the 1970s helped shape elements of the field as it exists today. Erikson raises concerns in the study of disasters that seek explanations and identifies trends in catastrophic events to help understand the effects of modernity in the 
United States. His work defies typical categorizations of disaster as an event with a beginning and an end, and goes to much greater lengths to think about how, when, and why a disaster happens, and to whom it happens. Importantly, he emphasizes the importance of psychological inquiry within sociological work, positing collective trauma as its own ongoing disaster. Like so many of the other thinkers whose ideas have influenced this project, Erikson is concerned about the demoralizing effects of the modern "state of affairs" that disasters expose and how they affect the way communities inhabit democracy and citizenship:

One reaction to that state of affairs is to withdraw into a dulled silence, sitting out one's life in front of television sets, inventing a more active life in fantasy, nursing old resentments, and spending a good deal of time tending the aches and pains of one's own body with the help of a heavy diet of medications. This is a form of resignation, the passivity of the longdistance spectator, and it is particularly acute among people who come to feel that the world operates by a logic alien to their own instincts. (Everything 257)

Emphasizing the need for intellectual understanding of the various ways that catastrophic phenomena relate to societies and civilizations, as disasters become ubiquitous outgrowths of modern technology, industry, and warfare, Erikson's approach to the field has helped carve out a path for further interdisciplinary exploration into catastrophe as a theoretical framework.

Foucault's consciously spatialized interpretations of power and society as relational processes within historical frameworks, particularly his concept of 
heterotopias, bears out the ideas of this project and opens the critical field of disaster for furthering projects that follow in the footsteps of disaster-oriented thinkers like Erikson, Klein, and Rozario. It is my hope that this project provides some examples of ways to fill gaps in the discourse of disaster and to more plainly engender an aesthetic and cultural acknowledgment of catastrophes as sites of inquiry, to enrich the possibilities for unearthing what geographer Kevin Grove says is the "often under-acknowledged politics of life" in disaster studies (198). 


\section{CHAPTER ONE}

\section{BURYING BODIES: CITIZENSHIP AND CIVILIZATION AFTER THE AMERICAN CIVIL WAR}

"The mystic chords of memory, stretching from every battlefield and patriot grave to every living heart and hearthstone all over this broad land, will yet swell the chorus of the Union, when again touched, as surely they will be, by the better angels of our nature." (Lincoln 27)

Mary Todd Lincoln died on July 16, 1882 at the age of 63 . Her obituary in the New York Times was published two days later and remarks that "although she was not a woman of exquisite refinement, nor a high degree of intellectual development [...] she believed in her husband [and] instinctively recognized in him the possession of qualities that remained hidden to his fellow countrymen long after his consort had prophesied great things of him." Emphasizing the struggles and sorrows of the widow during her lifetime, the brief biographical write-up entreats the public to have sympathy for her, as “the certainty that Mrs. Lincoln's reason was unsettled, must be borne in mind when we make any mention of the life, character, and actions of her who was the early choice and the long-beloved companion of Abraham Lincoln" ("Mrs. Lincoln"). While the public image of the First Lady can signify her position among myriad constellations of gender, race, and class, she also serves as a site of mediation for imparting ideological values to the public about the nation's political, cultural, social, and historical conditions. In the case of Mary Lincoln, one of, if not the most disliked of all the First Ladies in American 
history (Burns 28), the ideology of American democracy during the Reconstruction Era was an elaborate structure into which she simply did not fit.

Comparing the widowhood of the two First Ladies of the war-First Lady Mary Todd Lincoln and Confederate First Lady Varina Davis — as public figures of grief, this chapter analyzes nineteenth century cultural anxieties about how to make meaning of the losses of the Civil War, a catastrophe that called into question the capacity of the democracy to sustain its life as a Union, thus calling into question the purpose of patriotic sacrifice. These anxieties found expression through the popular embrace of Varina Davis's Old South as a metonym for the idealized Republic, and the rejection of Mary Todd Lincoln as a broken woman who figured the fractured realities of the nation.

This chapter uses the stories of the two First Ladies to interrogate the relationship between American citizens and the nation, analyzing patriotic political rhetoric against the material conditions of citizenship, civilization, and democracy as they variously figured during and after the Civil War. I juxtapose the antebellum rural cemetery movement with the Civil War as a starting point and a useful backdrop for studying the cultural significance of the war's unburied bodies and their impact on popular understandings of democracy in the U.S., as well as for analyzing the impact of the Reconstruction Era's turmoil on political rhetoric of democracy and union. Analyzing how patriotic significance is inscribed upon various representative bodies across these eras, we gain insight into some of the ways that Americans managed the traumas of the war after it ended and the ongoing and disparate consequences of these techniques for practices of democracy and citizenship in various communities. 
Nearly one hundred years after Lincoln's assassination, the (now) iconic widowhood of Jacqueline Kennedy was inserted into the American historical imagination after President John F. Kennedy was assassinated during a Dallas parade on November 22, 1963. A brief concluding discussion of the 2016 biopic, Jackie analyzes the film's portrayal of the widow as the intellectual architect of the Camelot framework that gave America its own brand of mythical royalty and ensured the Kennedy legacy by constructing a romantic "should-have-been" future that could never be. Raising questions about the pacifying effects of an ongoing mediation between the citizenry and its varied representative bodies who serve as symbols of citizenship, patriotism, and democracy, this chapter examines how these ideas have been articulated by linking American society with great civilizations (real and fictional) such as ancient Greece, the Old South, and Camelot.

\section{Rooting the Republic: Beautiful Burial and the Advance of Civilization}

In spite of the Revolutionary legacy of anti-monarchical sentiment, nineteenth century Americans were nonetheless conscious of charges that their country was uncivilized by European standards because of its historical immaturity and lack of national traditions (French 57, Bender 202). The 1831 founding of Mount Auburn Cemetery in Cambridge, Massachusetts, however, provided at least one solution to the nation's historical rootlessness. Prior to the growth of the rural cemetery movement spurred by Mount Auburn, Americans did not bury their dead with the hygienic sensibilities that are common today. The notion of a single plot of land in which to house a single coffin holding an individual body was not widely utilized or expected.

Americans buried their dead in whatever space was readily available, and as towns grew, 
old bone-yards were built over with no concern for the bodies below (French 40).

Looking more like a park than a burial ground, replete with walking paths, wellmanicured trees and flowers, and carefully tended ponds, the rural cemetery that Mount Auburn modeled stood in stark contrast to the usual burial sites that were typically located in the center of town. Far removed from the city, Mount Auburn Cemetery was located on the outskirts of town and showcased spacious gravesites amidst green pastures and rolling hills, as well as an experimental garden (Currie). This new model of burial pioneered the larger rural cemetery movement in the U.S. and prioritized aesthetic appeal for the living as a fundamental value. ${ }^{2}$

Welcoming mourners as well as picnickers and families on an afternoon stroll, rural cemeteries provided respite from the cities and encouraged Americans to reconsider the relationship between life and death as one where the spaces of the dead could be pleasant and hospitable. The bucolic beauty of the cemetery was so inviting, in fact, that one visitor exclaimed that, "“a glance at this beautiful cemetery almost excites a wish to die"” (qtd in French 38). Unlike the disorder of early burying grounds, which were often plundered by grave robbers (French 45), described by one visitor to America as “"soppy churchyard[s], where the mourners sink ankle deep in a rank and offensive mould, mixed with broken bones and fragments of coffins"' (qtd in French 44), the rural cemetery represented a more coherent method of organizing the dead and preserving the individuality of Americans even after they died. This spatial arrangement imparted a sense that people could truly stay in touch with their dead loved ones.

\footnotetext{
${ }^{2}$ The rural cemetery quickly became established as the new standard of burial in the U.S., with dozens of similar cemeteries built in northeastern American cities during the 1830s-like Brooklyn's Greenwood Cemetery and Laurel Hill in Philadelphia. By the 1840s, the movement had spread west and south into the larger cities, with many smaller versions showing up in small towns throughout the Republic by the $1850 \mathrm{~s}$ (French 53).
} 
Softening the harsh finality of death and soothing the grief-stricken, rural cemeteries offered a reverent space that invited the living to visit the dead and stay a while. More significantly, however, the cemeteries were championed as a way to elevate American society by representing the nation's civilized values. Comparing Mount Auburn to similar spaces in Paris and London (cities where such public landscaping efforts were already underway), the cemetery's Picturesque Pocket Companion characterizes the place as a necessary institution for civilized societies, tracing Mount Auburn's philosophical ancestry back to ancient civilizations like classical Rome and Athens (13). The function of the rural cemetery in the United States extended beyond providing the means to comfortably memorialize the individual and finalize a "good death" or to honor a life well lived, but to signify the privilege of national citizenship as conferred by burial in these grounds. Historian Alfred Brophy examines the rhetorical function of antebellum rural cemeteries for nineteenth century political leaders, whose consecration speeches typically emphasized the spaces as historically enriching; as signifiers of great civilizations; and as edifying sites of moral and patriotic instruction (27). These speeches often attached the cemetery to the nation by drawing comparisons between the cemetery and the U.S. Constitution, and by characterizing the dead bodies in these cemeteries as righteous models of American citizenship (7).

No longer the domain of the Church alone, the rural cemetery movement transformed the management of the dead in the United States, attaching spiritual significance to the nation and promoting meaning in death by suggesting citizenship as a sanctified state of being, even after death. Emphasizing the sanctity of the national community, Supreme Court Judge Joseph Story used his consecration speech for Mount 
Auburn to construct the cemetery as a patriotic gathering place where shared national affinities could bloom from the graves of the citizenry. Story's speech suggests the occasion of death as an opportunity for the dead and their loved ones to partake in the shared national subjectivity exemplified in the cemetery, offering Mount Auburn as a source of comfort and familiarity in the midst of sorrow - a site that provides security for the dying, who know they will be surrounded by fellow Americans, as opposed to dying in "unseen depths" in "the land of strangers" (5-6). Linking to the burial ground of Mount Auburn to the sacred soil of the nation, Story expresses what he calls the "feelings of our nature $[\ldots]$ in the desire to die in the arms of our friends; to have the last sad offices to our remains performed by their affection; to repose in the land of our nativity; to be gathered to the sepulchers of our fathers" (4). He characterizes the cemetery as a refuge for the living and the dead that would foster communal spirit, and where the opportunity for unity would alleviate the suffering of the bereaved as well as for the dying and the dead, all of whom would find comfort in knowing that they would have this hospitable place of eternal welcome.

Contributing to popular understandings about what it meant to be part of the Republic via the promotion of its role in bringing about a stable society, cemetery rhetoric encouraged thinking of these burials as the continuation of the life of the citizen into the nation's larger historical legacy, and hinged, at least partially on an "advance of civilization" trope that promoted stability in nationalist ideologies, leaning heavily on a construction of the Constitution as the source of the nation's stability and exceptional power (35). Brophy explains the driving force that linked cemeteries and the Constitution during this era as a contemporary belief among most scholars that human history was 
inherently didactic, and that the need for societal stability was one of the primary lessons of the past. Thus, "[h]istory taught that cemeteries served to bring stability to human society" (35) because of their function as socially stabilizing spaces.

The rural cemetery imparted a sense of transcendent national unity for citizens, an abundance of beautiful leisure spots, and a physical site on which to lay historical credibility and patriotic pride, but these changing conceptions of death and burial in the modern era also reflect a societal urge to control the uncontrollable and to avoid confronting the "unspeakable" reality of death's presence in day to day life (Walter 128). In seeking to partition the dead off into a separate realm—one which was physically distant from the hub of daily activity, but which was also aesthetically oriented to assuage the troubling realities of decay and disintegration which attend mortality-Americans were encouraged to believe that they could control and beautify the realities of death, and that this control could assuage emotions of grief, loneliness, and destitution (128).

\section{Bad Deaths: Civil War and the Decivilizing of America}

The bureaucratic attempt to control the presence of the dead, and the summoning of an imagined community of American patriots via this bureaucratic control was couched as a manifestation of the potential of the United States to advance as a great civilization on the world stage. The image of progress and unity so crucial to the success of this exceptional Republic, however, was contradicted by widening foundational cracks that often bore the label of "states' rights" issues. The most significant of these conflicts regarded the decidedly un-democratic institution of race-based slavery and its contested westward expansion in the United States (often described as an issue of property rights and economic freedom by southern slave-owning society, rather than an issue of human 
rights). The secession of a majority of southern slave states from the Union in late 1860 and early 1861 and the creation of a separate Confederate nation by these states prompted a war between the two sides that exposed a disunion so profound that it could not be overcome peacefully. ${ }^{3}$ This chasm within the union triggered an unprecedented spectacle of violent American death that could not be controlled or made beautiful.

Recent estimates place the death toll of the Civil War at over 700,000 (Hacker 307). The accumulation of dead bodies over the four-year span of the war confronted Americans - both soldier and civilian — with the terrible reality that a significant number of their fellow citizens would never get a proper burial. Studying the varied American responses toward death as they underwent dramatic transformations during the four long years of the Civil War, Drew Gilpin Faust's This Republic of Suffering examines the significance of the war as a catalyst for the development of new national institutions for handling the bodies of the dead and injured, defining this historical moment as a watershed for the "work of death" in the United States. The practical developments of systematized burial methods that Faust describes as an outcome of the war, however, did not come about in time to alleviate the ongoing trauma as it played out for the nation in the 1860s. Civil War battlefields were littered with unknown soldiers numbering into the thousands, and war department estimates calculate that "at least 25,000 were never buried at all" (L. Long 67). Even bodies that were buried might remain on fields for days after a battle before anyone managed to return to complete the grisly task (Faust 66-71).

In spite of the strides made in the nineteenth century to create a structural norm for controlling the messy realities of death, the enormous scale of the violence and suffering of the war overwhelmed Americans. In a diary entry from March of 1863,

\footnotetext{
${ }^{3}$ The Civil War lasted from April 12, 1861 to June 2, 1865.
} 
Adelia Lyon, wife of a Union Officer writes of the kind of hasty mass burial that was common during the war, "After dinner we walked to the burying ground, where the heaviest of the last battle was fought. There were a number of bodies picked up right here [...] After the last battle they dug pits and put from twenty to forty bodies in each grave" (Lyon 87). Battles were so near the homes of rural southerners that the sense of military order that accompanied traditional expectations of warfare was not present (Faust 39-42; Laskin 92). The distinction between soldier and civilian was already blurry, especially in the south, where a vast number of those who fought in the war were untrained volunteers (Faust 39) and where locals commonly took to nearby battlefields to examine the bodies of the dead, looking (often in vain) for familiar faces to find out firsthand if loved ones had died or to help bury soldiers (Castleman 236-7). Along with those who were searching battlefields for relatives and friends were others who were simply combing through the bodies' personal effects in search of valuable plunder (Faust 74). One witness writes in a letter that, “'[t]he countrymen about here had [...] taken every button and other article of value off the bodies. I saw one who had had a daguerreotype cut out from a case that was hanging around his neck; almost all had had their boots taken off their feet"' (qtd in Morse 47). Still others toured the battlefield with the sole intention of simply gawking at the carnage (Faust 85).

The callous treatment of the bodies of these dead soldiers was happening in a very public way and on a massive scale, and it seemed that no one was able to do anything about it. ${ }^{4}$ A September 5, 1862 letter from Confederate solider Walter Battle describes

\footnotetext{
${ }^{4}$ Faust's monograph does discuss how the infrastructure of both the North and the South improved over the four-year span of the war, and that methods of mass identification, burial, or transport were developed precisely because of the inadequacies so evident in the early years. Nonetheless, those inadequacies of the early years had a dramatic effect on the nation at the time.
} 
the tremendous volume of dead bodies in some of the battle zones and the impossibility of attending to each one individually:

Day before yesterday we marched over the battle ground that Jackson had his last fight on. All of our men had been buried, but the Yankees lay just as they were killed. I never saw such a scene before. I saw just from the road, as I did not go out of my way to see any more. It must have been nearly a thousand. Our wagon actually ran over the dead bodies in the road before they would throw them out, or go around them [...] I recollect one squad on the side of the road with their bush shelter in ten steps of a dead Yankee, that had not been buried and was horribly mangled. I don't suppose the dead Yankees of that fight will ever be buried. (Battle 74-5)

The unburied, unidentified bodies that filled the landscape of battlefields made it impossible for Americans to ignore the horrors of war, but also made it clear that loved ones who may not make it home alive may not, in fact, make it home at all. Civilians and surviving soldiers were forced to live with the ever-present reality that tens of thousands of their countrymen lay decaying on the ground and there was nothing to be done to alleviate the neglected, abused anonymity of these citizens.

For those not living in close proximity to the battle sites, the objectification of the dead soldiers was reified in the photographs of the bodies. The rapidly evolving technology of photography made these and other realities of war accessible to Americans far from the battle lines and evoked a collective sense of both revulsion and awe at a vision of war that many had never seen before. In contrast to the newly adopted custom of commissioning postmortem photographs - a practice intended to display the 
individuality and beauty in the bodies of the deceased by posing them as though they were alive (Troyer 27-9) - most Civil War photos of the dead captured them as they lay where they had fallen, in bloody battlefields. ${ }^{5}$ These fields, strewn with dead men lying in awkward positions, often without boots and with features so distorted they rendered the men unidentifiable, were visual symbols of the brutality of war and of the human cost of the nation's internal fracture.

The public reaction to photographs taken from the battlefield at Antietam, the site of one of the most gruesome battles of the war, reflects the inexplicability of the experience of seeing such scenes for the first time. An 1862 New York Times piece describes the effect of the photographs on northerners, who had access to these photographs through public displays:

Of all objects of horror one would think the battle-field should stand preeminent, that it should bear away the palm of repulsiveness. But on the contrary, there is a terrible fascination about it that draws one near these pictures, and makes him loth to leave them. You will see hushed, reveren[t] groups standing around these weird copies of carnage, bending down to look in the pale faces of the dead, chained by the strange spell that dwells in dead men's eyes. ("Brady's Photographs")

As the New York Times article on the photographs summarizes: "If [Brady] has not brought bodies and laid them in our dooryards and along the streets, he has done something very like it." Having grown accustomed to understanding the "good death" as one that entailed a deathbed scene, confessions, and familial comfort (Linderman 109-10;

\footnotetext{
${ }^{5}$ It should be noted that photographers of the time reportedly altered the scenes of the dead bodies, adding or removing objects like muskets, and possibly moving bodies on occasion, in order to create the images they wanted (Zeller 107)
} 
Faust 8-11), Americans now gazed upon massive numbers of their fellow countrymen decomposing in fields all across the south.

If the order and reverence of the rural cemetery signified American citizenship as a sacred status that conferred a patriotic afterlife on its citizenry and imparted a sense of comfort in the notion that the living and the dead could experience a sort of domestic harmony in the idyllic landscape the cemetery provided, then the images of the neglected bodies of soldiers signified the meaningless death of nationless people with no identities, no homes, and no afterlives. What these pictures did for, and to the public was vastly different from the function of traditional postmortem photographs, which were supposed to guide the bereaved slowly through the process of grief (Troyer 27-8). These battlefield photos instead summoned a terrifying image of the dead that linked their bodies to the nation, not as valiant symbols of patriotic sacrifice on behalf of civilization, but as symbols of a rootless regression from civilization, a society devolving into chaos.

A Union soldier who later became a well-known journalist, essayist, and fiction writer, Ambrose Bierce wrote multiple fiction and non-fiction pieces about his years in the Civil War. His work presents a critical view of the war and frequently references the indignities that the civilian population and the state and federal governments committed in their readiness to leave behind countless unburied soldiers on both sides of the conflict. Conjuring the surreal experience of fighting in the Civil War, Bierce's writing captures a sense of banality in the horrors of combat, as soldiers grew accustomed to the carnage. In his autobiographical essay on the Battle of Chickamauga (in Tennessee), which was fought in late 1863, he recounts the effects of what he now sees as an absurd theater of 
violence and he conveys the degrading impact of such violence for both the dead and the living: ${ }^{6}$

When all was over, and the dust cloud had lifted, the spectacle was too dreadful to describe. The Confederates were still there-all of them, it seemed — some almost under the muzzles of the guns. But not a man of all these brave fellows was on his feet, and so thickly were all covered with dust that they looked as if they had been reclothed in yellow.

"We bury our dead," said a gunner, grimly, though doubtless all were afterward dug out, for some were partly alive. (Bierce 30)

This unsettling description of men covered in dust connotes disintegration, despite the fact that they have just been killed. It is as though these soldiers have been lying dead and unattended for a long while. Defining features of the men have been rendered invisible by the dust, and though they have only just fallen, they lie like neglected objects: dusty, forgotten, and indistinguishable from one another. The revelation that some of the men have been buried alive is delivered with a calmness that suggests that in such a space as this, confusing the living for the dead is much more common than one might think. Bierce's use of the term "partly alive" to convey this idea also foreshadows the impending death of the men and hints at the slow, painful demise that frequently resulted from battle casualties. The condition of being "partly alive" also suggests that it is possible to be alive and dead at the same time, and points to the inevitable fate for a significant portion of the men in the U.S. at this time: statistically speaking, many who had yet to see any fighting at all when Bierce fought at Chickamauga were perhaps only

\footnotetext{
${ }^{6}$ This battle took place on the Tennessee-Georgia border September 19-20, 1863 and is considered the bloodiest battle of the western theater (Woodworth 1).
} 
"partly alive," as we now know that many of their lives would soon be at an end.

Beneath Bierce's retrospective discomfort about the fates of so many soldiers lies the unnerving reminder that to live in the midst of such horror is to exist simultaneously among the realms of both the living and the dead. The soldiers of the Civil War were living in death with every new battle. Nineteenth century practices around grief that included visiting the dead and displaying postmortem images of lifelike bodies promoted the idea that traces of the dead could still exist in some sort of harmony with the living through attending to the memories and bodies of these departed loved ones. The war overturned these notions, when predominant imagery evoked a sense that perhaps the dead were overtaking the world of the living. The harsh reality of the Civil War was impossible to ignore, and antebellum ideas about order and stability that had seemed so promising in the serene landscapes of the rural cemetery were no longer viable. The sensory assault of these realities about the nation — whether in visual imagery of war photography, or in the smells, sounds, sights, and bodily experiences by those living or fighting in the war zones - was at odds with the mission of stability and progress so carefully crafted by the ethos and imagery of rural cemeteries and the patriotic sanctity of burial within them. The unburied bodies of the Civil War dead exposed the fragile façade of harmony in the rhetoric of the Republic as a myth that could not counter the very real experience of the crumbling civilization in which Americans lived.

\section{Burying (Some)Bodies: Gettysburg and the Future of the Republic}

The battlefield at Gettysburg was one of the more horrifying scenes that civilian Americans glimpsed of the chaos that was their nation during the war. "Gettysburg made

\footnotetext{
${ }^{7}$ Though the battle was fought in late 1863 , the final two years of the Civil War saw roughly $50 \%$ of its deaths, and even in fighting that took place after the Battle of Chickamauga, which had a death toll of over 34,000 men, around 200,000 men would still die ("The Civil War by the Numbers")
} 
the dead - and the problem they represented — starkly visible to northern citizens," writes Faust, adding that the gruesome site so intrigued the relatively sheltered northerners that many of them "flocked to the small Pennsylvania town in the aftermath of battle" to see the carnage firsthand (Faust 99). In November of 1863, when President Lincoln consecrated a new national (ie: Union) cemetery at Gettysburg on the site of the bloodsoaked battlefield, his Address was concurrent with a massive re-interment project that was already underway on the site. The project was attempting to make right the wrongs of such ignoble battle deaths by digging up the hastily buried Northern soldiers and properly identifying and interring them in this new sacred national space, albeit four months after they had fallen. The mass exhumation was an infamous spectacle in Gettysburg for months, as the process of honoring the dead assaulted the olfactory senses of all who lived or traveled in the vicinity (Faust 69).

Memorializing the soldiers at this site was significant, in part because of the nightmarish battle scene that the orderly re-burial was attempting to redeem, but also due to the fact that the cemetery was proudly democratic; no one soldier's grave enjoyed higher status in death than another (Faust 100). All of these soldiers were equal in the eyes of the nation and the sacrifices of each Union man were the proof of his virtue. After such a sacrifice, the fate of the citizen would now be inextricably linked to the fate of the Union in the national memory, and the Gettysburg Cemetery underscored the nation's political authority in exercising responsibility for honoring and burying the Union soldiers. "No longer simply the responsibility of their families, they, and their loss, now belong to the nation," writes Faust. "These men had given their lives that the nation might live; their bodies, repositories of their 'selfhood' and 'surviving identity,' as 
Harper's had put it, deserved the nation's recognition and care" (100-1). This method of channeling an epic scene of carnage into a patriotic sacrifice was effective in part because of the construction of the national cemetery as a site of patriotic transformation, like the antebellum rural cemetery had been. Lincoln's Gettysburg speech hearkens back to tropes familiar in so many antebellum cemetery consecrations, imagining the Republic as a unifying theme in the lives and deaths of citizens (Brophy 63).

The Address rhetorically links the country's soil with that of the nation and sanctifies both by using the deaths of its soldiers as evidence of their sacredness, making martyrs out of the soldiers and a righteous cause out of the war. The themes in Lincoln's speech, like those of antebellum cemetery consecrations, cast the soldiers' deaths as sacrifices to a higher national honor-sacrifices that redeem the terrors of the war and make them virtuous through the spiritual principle of patriotism (63). Focusing on hope for the unity of the nation, as it will be, after this harrowing moment has passed, the Gettysburg speech extols the virtues of the dead by emphasizing the harmony of the Republic as it lives on in the citizenry. Evoking the future-oriented "advance of civilization" theme, Lincoln echoes the idea of the national cemetery as a repository for the dead bodies as historical subjects who serve as lessons in righteous patriotism: "It is for us the living, rather, to be dedicated here to the unfinished work which they who fought here have thus far so nobly advanced $[\ldots]$ and that government of the people, by the people, for the people, shall not perish from the earth" (Lincoln). This recasting of death and disorder in the consecration speech and reburial project of Gettysburg shows how the nation could be redeemed in its horrific material conditions via the promise of an idealized future civilization, and how the past could be reorganized to allow for a more 
comprehensible future. ${ }^{8}$ As the war continued beyond Gettysburg, the sight of the unburied dead could be reconciled with this idealized version of democracy by Lincoln's assurances that the nation would not forget these sacrifices for the Republic and that the "unfinished work" would continue.

The Address conjures a future for the dead soldiers, who will always be remembered for their sacrifices to the legacy of the great civilization that is the Republic, and although Lincoln does not mention Athens, his speech bears strong resemblances to Pericles' Funeral Oration. Simon Stow notes how the two leaders' respective addresses functioned similarly for their societies in generating a sense of political unity amongst the war-weary citizens (195) projecting the future as a landscape of hope and reunion. In Lincoln's emphasis on the war as "at most a civil war-despite the obvious Southern claims to the contrary," Stow notes the President's judicious use of the word "nation" five times in the brief Address (202 his emphasis). Lincoln attributes a lofty, civilizing mission to the war that characterizes it as a nationwide construction project of strengthening democracy and generating national harmony, framing it as a chance to build the Republic into an even better version of itself than it had been before. The stakes of the war as Lincoln presents it to the American people in the Gettysburg speech are nothing less than civilization itself in the fate of the Union.

Constructing transcendent historical relevance to citizenship and sacrifice, as Pericles' Funeral Oration had done for the citizens of Athens, Lincoln likewise

\footnotetext{
${ }^{8}$ Susan Mary Grant sees the American Civil War as a key moment to consider in the larger global turn toward modern nationalism, as this memorialization of the dead in the historical context of national war and its sacred emplacement is, in her estimation, actually the precursor to European nationalism reflected in similar models, such as in Germany during and after WWI (Grant 512). "[T]he Civil War was, as Abraham Lincoln put it, 'a people's contest', fought largely by volunteer troops on both sides, and productive of an equally emotive sense of nationalism," writes Grant. "In attempting to assess how and in what ways the war dead became so central a component of modern nationalism," she writes that "the American example is clearly apposite, and deserves greater consideration than it has hitherto received" (511).
} 
contributed a lasting legacy of American democratic virtue in casting the Civil War dead as idealized subjects whose souls would now rest in harmony with the soil of the nation. Generating an imagined community of the nation (even at war with itself), the Gettysburg Speech performed the same controlling, beautifying functions for the Republic that the rural cemeteries (and now the national cemeteries) performed. The ongoing popularity of this speech, which was almost immediately celebrated as one of the great speeches of the war (Stow 203) supports Russ Castronovo's assertion that such an ideology of democracy can be classified as what he calls a "necro ideology," a political ideology specific to nineteenth century American culture, and which uses metaphors of death to define democracy. Such a linkage, in Castronovo's assessment, ultimately renders ideal citizenship as a passive, docile condition. Necro ideology "eternalizes sociohistorical relations as neither social nor historical by conceptualizing the unmarked soul as refuge from the politicized body, idealizing the afterlife as a perfected social order" (13), which, in essence, supports the sanctification of the war dead as emblems of sacrifice. As a rally cry for the Republic that averts attention from the present political moment—-figured by the dead bodies all around him — the necro ideology of Lincoln's Gettysburg Address evokes what Castronovo calls the transcendent "airy conditions" of the abstract theoretical constructions of democracy, privileging the ideological abstraction over the material reality on the ground.

A source of ongoing tension within the necro ideological democracy of the U.S. is that inevitably, as this disembodied ideology transcends particular socio-historical conditions as they exist in reality, those same material conditions (of violence, slavery, and injustice) that are visible in the bodies of subjects who do not fit into the ideal model 
of citizenship cannot be abstracted into universalized necro citizens, which requires Americans to somehow reconcile these contradictions:

those very subjects are the evidence that there is a 'materialist counternarrative [that] desublimates abstract renditions of personhood and nation, spelling out instead what Marx calls 'the putrescence of the absolute spirit' - that is, the decay of an ideological consciousness that falsely transcends the palpable matter of human life as so many 'phantoms.' (13)

Those whose are excluded from this society because of their discordant material embodiment are thus embodying the contradictions in the ideology of this democracy. Blacks both free and enslaved, for instance, as well as other people of color, women, and even poor southern whites who were disproportionately dying to preserve a system that had kept them in poverty for generations, continued to embody the Marxian "materialist counternarrative" that Castronovo describes. President Lincoln's speech put forth the "airy conditions" of redemptive patriotic meaning as a way to transcend the embodied consequences of this very patriotism as they were exhumed and reburied in the soil of the national cemetery. The failures of the Reconstruction Era, however, would problematize the lofty ideology of the idealized Republic and bring about a new version of ideology that justified Jim Crow in the south and rampant segregation and racial violence throughout the nation.

\section{Romancing the Past: The Rebirth of a Nation}

During the weeks and months following Confederate General Robert E. Lee's 
surrender to Union forces and Lincoln's assassination five days later on April 14, 1865, ${ }^{9}$ Northerners and Southerners grieved their losses and perceived the significance of their tragedies in a variety of ways, and these manners of reconciliation impacted the Reconstruction Era and turn of the century significantly. Themes of sacrifice, martyrdom, and destiny provided a potent rhetorical salve for the emotional, physical, and spiritual wounds that so many had suffered. These coping mechanisms became entrenched as common refrains in popular speeches and analyses about the war and its major figures throughout the late nineteenth century (Faust 156-61), and over time, the virtue of sacrifice became justification unto itself as a reason for the war, offering a sense of comfort amidst the deep troubles and uncertainty of the moment (193). Especially as the Reconstruction Era policies began to falter and eventually dissolve after the contested Presidential election of $1876,{ }^{10}$ the romantic myths of valor and epics of sacrifice that had figured so powerfully in the rhetoric of democratic politics were channeled into backward-looking constructions of an idealized past.

As the nineteenth century ended, the reverberations of grief and shock that resulted from the years-long spectacle of suffering and death of the war became sublimated through memorials and nostalgic expressions of a past that had never existed, and a sense of national pride attached itself to these representations of the past. Describing the insidious and ongoing legacy of the mythology of the rhetoric of the

\footnotetext{
${ }^{9}$ The war did not officially end until June of 1865, but when General Robert E. Lee surrendered to Ulysses S. Grant at the Appomattox Courthouse on April 9, 1865, the war was unofficially over, as the most important figure leading the Confederacy had finally conceded victory to the Union.

10 Though Democrat Samuel Tilden won the popular vote and led Hayes by 19 electoral votes, 20 contested votes delayed the election results, and after a contentious legal fight, the courts decided to award the 20 votes to Hayes, giving him the Presidency. This decision created a deep sense of distrust in the election process, and when Federal troops pulled out of the South soon afterward, many came to believe that Hayes had made an agreement with Democrats to leave the region in exchange for the Presidency. This is around the time when the Jim Crow era began in the South (Guelzo 510-11).
} 
southern "Lost Cause," Tony Horwitz refers to the ideology as the mythical "romance" of a harmonic and graceful antebellum south, a myth that sustained itself for generations against the material realities and disappointments of the Civil War and Reconstruction, which by contrast seemed all the more troubling to address and resolve. The ideology that so comforted and captivated southerners recast the war as "an epic might-have-been," writes Horwitz, "a 'defeated victory' in which the valorous South succumbed to flukish misfortune-Johnston's untimely death, for instance, or Stonewall Jackson's mortal wounding by his own men at Chancellorsville" (172).

Monuments to Confederate heroes, and memorial groups like the Daughters of the Confederacy made their way into the southern landscape of historical remembrance in the late nineteenth century (Hoelscher 663). This impulse to preserve and restore the imagined way of life that had been destroyed by the Civil War actually manifested some of the most brutal conditions of the antebellum south anew: segregation became institutionalized and formal subordination enforced in southern (and northern) cities, state and local statues disenfranchised blacks via legal loopholes under the "states' rights" banner, while unjust penal codes and convict lease systems produced unofficial versions of race-based slavery, simultaneously condoning terrorism against ethnic minorities (or their supporters) through extra-legal racial violence and lynchings, much of which was proudly organized and/or celebrated by white supremacist groups who existed solely to preserve the antebellum system of governance in the south (Woodward 41, 43, 59-63, 8587).

Collectively mourning the loss of the antebellum "way of life," with its clear-cut social (and racial) hierarchy and thriving agrarian economy, the South's reframing of the 
Civil War as a "War of Northern Aggression" transformed it into a great Cause-an epic defense of the Confederacy. This Cause, as it was constructed in the mythology, was the defense of an innocent nation against an invading Union who sought to control it and to destroy the economic and social stability it had achieved. Many southerners used this mechanism to channel their suffering into a kind of religious zeal for Confederate iconography, using their collective spiritual and emotional attachment to this version of the past to find a way to accept, or at least give meaning to their tragedies. In their nostalgic reverence for the imagined agrarian simplicity of old, the north and the south were quite similar (Linderman 268-71).

Rather than emphasizing the war's role in shaping the conditions of the present or the future, as speeches like Lincoln's Gettysburg Address had done, much of popular rhetoric from the 1870s onward placed the war dead alongside themes of sacrifice and stability to deploy an imaginary past that ignored the realities of the conflict and its aftermath. In the 1880s and 1890s, especially, the cynical frustration of the Reconstruction Era shifted into an era of forgetting, often through memorial (Faust, 1904) ${ }^{11}$ The north and the south were united in their joint concerns with re-imagining the past and using the sacrifices of the dead to create a new meaning via memorialization, and Faust emphasizes the significance of the war's dead bodies for this particular public "project" of national reunification. Although she points out that the dead had initially "served as the repository of continuing hostility between the North and South" after the war ended, she adds that the dynamic changed considerably over a short span of time,

\footnotetext{
${ }^{11}$ Historian Allen Guelzo describes the Reconstruction atmosphere as a cynical era, emphasizing the profundity of Americans' disappointment at the failure of Reconstruction policies to repair the broken nation after its tragedy: "The American generation that inherited this bleak landscape despised itself as no other American generation since," he writes, noting that it had been dubbed the "Gilded Age" because of its hypocrisy and "soul of lead" (521-2).
} 
and that "by the end of the century the Dead had become the vehicle for a unifying national project of memorialization. [...] The Dead became the focus of an imagined national community for the reunited states, a constituency all could willingly serve" (269). Burgeoning cults of devotion sought to redeem the nation's Reconstruction Era "soul of lead," and reconcile its self-destruction with the ideal of the Republic as a harmonious civilization. At the same time, a corresponding impulse to gloss over the complex and fragile socio-political conditions of the contemporary post-bellum landscape manifested in a political attachment to the Republic as it existed in the imagined history of the nation.

Discourse that located an imagined national community in shared sentimental regret over the nation's loss of its "simpler" and agrarian life grew increasingly popular, as Americans now sited their conceptions of progress and civilization in stability and order, which was at least partially provided by these idyllic constructions of the "old fashioned" way of American life. In his seminal work on the Gilded Age, Robert Wiebe's The Search for Order highlights this popular rhetoric as a reflection of changing selfconceptions of late nineteenth century Americans as they desperately sought some sense of coherence in their democracy, after years of chaos and confusion. He writes of the era's "obsession" with the imagery of the imagined past as an agrarian utopia:

A flood of friction sighed over the lost virtues of another day: the valiant men of the Wild West, the touching warmth between master and slave, the $\mathrm{qu}[\mathrm{ie}] \mathrm{t}$ peace of the New England village, the happy innocence of the barefoot boy with the cheek of tan. The peculiar ethical value of an 
agricultural life, long taken for granted by so many Americans, now became one of their obsessions. (39)

Knowing that they would not realize the great civilization Lincoln had promised through national politics or find a sense of security in the broken promises of politicians, Americans reframed the search for order via an imagined history, which served as both a shared history and an idealized civilization. These controlling images of agrarian society in the culture and politics of the U.S. operated to organize and beautify the ugly realities of American post-bellum society, much as the antebellum cemetery had done for the ugly realities of death.

\section{Weak Link: The Deaths of Mary Lincoln}

In the necro ideological realm, the citizen is incapable of dying because he/she exists in the transcendence of a disembodied democracy that figures American citizenship in sanctified bodies of imagined civilizations who are nonetheless purely ideological (Castronovo 37), akin to the citizen whose death is sanctified by virtue of his/her burial in the soil of the national cemetery. The homogenizing realm of necro citizenship promotes a democracy defined by passive acquiescence, as citizenship is conferred only on those whose embodied existence aligns with the necro ideological "airy conditions" of democracy, while subjects whose embodiments do not align with this construction are "exposed to political injury" or "social death" (Castronovo 37). Perhaps the polyvalence of Ambrose Bierce's phrase "partly alive" could apply to the widowhood of Mary Lincoln alongside the buried-alive soldiers at Chickamauga. As an embodiment of social and political death, the former First Lady's brokenness was an abhorrent reminder that the nation, too, was broken. 
The Lincolns, like most public figures, endured contemptuous assessments and rampant gossip during Abraham Lincoln's Presidency. Though Mary was well educated and raised in a wealthy home in Lexington, Kentucky— the "the Athens of the West," as it was sometimes called (Baker 55) — she was still not quite sophisticated by D.C. standards. The state of Kentucky, only relatively recently settled, was "western," a habitat viewed as only marginally more civilized than an untamed wilderness (166). The President was also a westerner and had often been the butt of jokes about his manners and country accent (Hendricks 127-8). A journalist who had traveled with the newly elected President on his inaugural tour wrote that in appearance and personality, Abraham Lincoln was crude, with "the most unprepossessing features, the gawkiest figure, and the most awkward manners. Lincoln always had an embarrassed air, too, like a country clodhopper appearing in fashionable society, and was nearly always stiff and unhappy in his off-hand remarks" (Villard). The President was ridiculed mercilessly during his time in office, but as the war continued, Mrs. Lincoln became ever more subject to harsh judgment from the presses and her social circles for etiquette offenses of various kinds (Anthony 170).

Concerned about public opinion and seeking to dispel the perception that she was backwoods and crude, Lincoln proudly wore the latest fashions and redecorated the White House extravagantly. This, however, was a double-edged sword, and when she overspent the White House budget for redecorating and had to request additional appropriations from Congress, the First Lady drew considerable ire (Baker 187-91). The public soon found reason to denounce her as a spendthrift, while upper class northerners saw her frenzied overindulgence as proof of her gauche sensibilities (McCreary 205-7). 
Mary's perceived incivility toward her husband's colleagues was another strike against her. She had been raised to think independently and encouraged to form her own judgments, and her intellectual assertiveness and quickness to make her opinions known among important politicians earned her a great deal of censure from both men and women in her male-dominated society, which cast her as at once ignorant and arrogant (Baker 180-1). Charges of bad taste, careless spending, and an overly ambitious personality plagued the First Lady for the duration of the Lincoln Presidency (Winkle 912; McCreary 214-5).

Criticism of Mary Lincoln grew even more vitriolic as the years passed. Upon the death of her son, Willie, in 1862, Mrs. Lincoln underwent an extended period of grief and wore her mourning dress for two years. The common custom of the time was to spend one year in mourning for a child, and Lincoln was displaying "excessive" grief by extending her mourning (McCreary 210-1). As much as her inappropriate spending and forceful disposition, the view of Lincoln as self-indulgent in her "immoderate" grief particularly galled Americans of all social classes, many of whom were dealing with losses of their own, and could not afford to devote such attention to their sorrows (Hendricks 129, Baker 216). ${ }^{12}$ Rather than inciting sympathy for her losses or support in her social endeavors, Lincoln's blunders in society—especially after the President's death—evoked ridicule from the public and from former acquaintances and friends. Mistakes in judgment became justifiable excuses for attacks on her personal character, and eventually, they became justification for her banishment from society.

\footnotetext{
${ }^{12}$ Rather than extensively detailing the rumors and criticism of Lincoln during her years as First Lady, I focus on the public reception of her during her widowhood and do not dwell on her time in the White House. There is a lengthy discussion of Lincoln's public reception during the Presidency, however, in Jean H. Baker's biography of the First Lady.
} 
Just two years after the President's death, his widow attempted to organize a sale of her gowns from the White House years as a way to raise funds, ${ }^{13}$ a debacle which has become known as the "Old Clothes Scandal." Knowing the dangers of revealing herself to the public as the seller, and uncomfortable with the attention her name might create in the papers if her efforts were revealed, Lincoln used her dressmaker and close friend, former slave Elizabeth Keckley as her agent in communications with the dealers who would be organizing the sale. Word of her involvement got out nonetheless, and the presses printed sensational stories that portrayed Lincoln as a pathetic figure whose poverty forced her to peddle her own clothes, once worn ostentatiously in the ballrooms of the White House. ${ }^{14}$ Lincoln was socially destroyed by the gown exhibition, where her dresses were “"tossed about by frequent examinations,"” "“exposed upon a closed piano, and upon a lounge," where one newspaper article made a point to mention that "“they are jagged under the arms and at the bottom of the skirt, stains are on the lining, and other objections present themselves those who oscillate between the dresses and the dollars "” (qtd in Keckley 304). This public humiliation only intensified when the World published a number of her private letters shortly after the sale. Mercilessly shamed by the press and mocked by the public, Lincoln made almost no money from her dresses (Hendricks 131).

When Keckley decided to write her personal memoirs shortly after Lincoln's public disgrace in New York, she stated that she hoped her insights about the former First Lady would set the record straight and put an end to the scandalous reports about her. Keckley's memoir recounts-in spite of Lincoln's early claims that she had not authorized the sale - that in fact, Lincoln "gave Mr. Brady permission to place her

\footnotetext{
${ }^{13}$ Whether Lincoln actually needed the funds is debatable (Baker 280).

${ }^{14}$ This was actually a common practice among wealthy women, especially during the Civil War (BoykinChesnut 395).
} 
wardrobe on exhibition for sale, and authorized him to publish letters in the World" (296). In addition, Keckley includes private, emotional letters from Mrs. Lincoln alongside newspaper excerpts that discuss the scandal. In spite of Lincoln's flimsy attempts to distance herself from the event, it was clear that she had authorized the sale of the gowns and the publication of her personal letters in reference to the sale. She had deliberately put her private life on display, and in so doing had terribly miscalculated the public's estimation of her social standing and society's valuation of relics from an era that they were eager to forget.

The irony of Keckley publishing private correspondence from Mrs. Lincoln where the widow discusses the incalculable problems caused by the publication of her private letters is heightened when, in one of Keckley's published missives, Mrs. Lincoln describes a scene on a train where she silently observes two men reading about her letters in the news. The two men sat just in front of her, but because she wore a veil, the duo was unaware that the subject of their gossip could hear every word they said. Lincoln recounts to Keckley that she had been watching the first man, an older "respectable-looking gentleman" as he read the New York World article that had printed her personal correspondence and sensationalized the dress sale, characterizing Mrs. Lincoln as a poverty-stricken beggar (Keckley 297). A second man sitting beside the reader engaged him in a discussion about the article and the two discussed the sale. When the second man remarked that the proceeds would allow the widow to purchase a funeral plot, Lincoln writes that, "[t]he World man turned towards him with a searching glance, and replied, with the haughtiest manner: 'That woman is not dead yet'” (Keckley 298-9). Not dead yet, but no longer fully alive, the quality of Lincoln's life was vitally tied to her 
husband's life and legacy and to her public reception in the U.S. This moment on the train exemplifies a larger dynamic between Lincoln and post-bellum Americans; by turning her personal struggles into public spectacles and then watching helplessly as strangers passed judgment on her very existence, she reduced herself to an abhorrent reminder of the war - a metonym for the fragmented and precarious state of the nation as it had been exposed by the dead and unburied bodies of its citizens.

From 1868 through 1871, Lincoln traveled abroad, referring to herself in a letter to a friend as an "exile" (Baker 351), but nonetheless living a relatively quiet existence with her son Tad. Only upon her return to the U.S. in 1871, shortly after which Tad unexpectedly died at the age of 18, did Mrs. Lincoln again encounter public humiliation (Emerson 31-4). By 1875, Mary's remaining child, Robert had grown frustrated at his mother's emotional instability. Her paranoid worry that Robert was going to die at any moment, combined with melodramatic mood swings and a never-ending need for reassurance vexed him greatly, especially when her behavior was discussed in the newspapers (Neely and McMurtry 8-11). With the help of several leading politicians and doctors, Robert had Mary forcibly detained for a public trial, where she was declared insane and subsequently institutionalized at Bellevue Insane Asylum (Baker 284).

Mary's exclusion from post-bellum society reflects the values of her society as much as it reflects her own inadequacies. Norbert Elias's framing of civilizations as processes defined by flux (outlined in what he calls "civilizing processes" and "decivilizing processes") explains why Mary Todd Lincoln may have been especially vulnerable to social and cultural rejection by Americans after the war. During the "decivilizing process" of the war, antebellum social hierarchies and public etiquette 
necessarily became more lenient. Many attitudes and behaviors that would have been inappropriate before the war became common across all social classes, as most Americans on both sides of the conflict were focused on the immediate moment, with concerns about battle victories or losses, food shortages, economic instability, casualties and deaths of loved ones, and protection against desperate deserters and guerillas occupying their daily lives (Smith 35-6).

Imagining a stable future was all but impossible in the uncertainty of a four-year civil war, and all of American society was forced to adapt to the crisis. Expectations shifted again after the war's end, however. In a complex society whose hierarchical relationships were being rebuilt and strengthened as the war was rapidly pushed into the sphere of memory and the "civilizing chains" of society were becoming reestablished, the expectation for a woman in a public role such as hers was no longer the same as it had been during the conflict. Elias points out that as a society becomes more civilized and complex, individual social roles grow increasingly dependent upon the stability of the social structure and thus, upon other members of society. If an important "link" in the "civilizing chain" is faulty, the chain is weakened and the society becomes vulnerable (Elias 54-5). It is remarkable when we look back at the body of literature that discusses the mental state of Mary Todd Lincoln that of the main reasons she was declared insane, most were reflective of the same kind of psychological tension that would besiege the minds of citizens who were watching their society destroy itself through Civil War: deep fears of poverty, inconsolable worry over her last living son's health and well-being, and frequent outbursts of panic and emotional anguish. Although as she was inadvertently reminded by a stranger on a train that she was "not dead yet," Lincoln was socially and 
politically dead, unable to participate in society and, in fact, forcibly removed from it, declared unfit for even a marginal public existence, only "partly alive" in this post-bellum America.

After four months in Bellevue and with help from feminist activists Myra and Judge James B. Bradwell, Mrs. Lincoln was able to secure her release (Neely and McMurtry 21). From her release in early 1876 through 1880, Lincoln again traveled abroad, rarely staying in any one place long enough to feel at home. She returned to the States in October 1880 only because her health was declining rapidly. Mrs. Lincoln died on July 16, 1882. Springfield, the town where she and Abraham Lincoln had settled in the early years of their marriage declared a national holiday upon her death and held a lavish funeral for the former First Lady, celebrating her as a representative of their city only after her death (Baker 369).

The sanctity of the rural cemetery ensured that the life of the citizenry would continue in the life of the Republic, but for four years, the Republic was on the verge of death and untold numbers of citizens went unburied. After the war ended, its meaning also changed. No longer in the midst of a fight for national survival, the country was piecing itself back together during the Reconstruction years and figuring sacrifice, citizenship, and civilization through different ideological constructions. Rather than rallying around the widow of their fallen President in a show of solidarity as it healed from the deep wounds of the war, the American public instead collected itself around illusory images of fortitude and wholeness that mirrored its idealized Republic of stability and control. Northern society's admiration of Varina Davis - especially in the later years of her life, after the death of Jefferson Davis in 1889 - is worth exploring against the 
public rejection of Mary Lincoln, because unlike Lincoln, Davis had not been a

representative of the Union, but of its enemy. Davis, in her southernness, managed to lay

claim to a set of attributes that appealed to public sentiment far more than those of the

former First Lady of the United States. ${ }^{15}$

\section{The "Better Angels of Our Nature": Varina Davis's Old South}

The public appetite for southern memoirs during the Victorian Era-especially in the north - speaks to Americans' nostalgic desire for a romanticized past that embraced figures of grace and gentility, even if these figures were not necessarily reflective of the majority of the populace (Marten 303-4). There are many reasons why Varina Davis was a more acceptable public figure than her Union counterpart after the Civil War, not the least of which was that her southern aristocratic heritage stood in stark contrast to Mary Todd Lincoln's uncouth "western" upbringing and unrefined social faculties. ${ }^{16}$ Varina Davis's popularity in the north during the later years of her life was due, in part, to her columns in the New York World, which mostly drew on her experiences in the antebellum south and her life during the Civil War years. ${ }^{17}$ Upon Jefferson Davis's death in 1889 , his widow used her family connection to Joseph Pulitzer (who had married a Davis cousin) to obtain a position with his popular newspaper and she and her daughter Winnie moved together into a hotel suite in the city, where both women enjoyed moderate success as

\footnotetext{
${ }^{15}$ Mary Lincoln had been dead for seven years before Davis was widowed, so it is important to note that her downfall was not concurrent with Davis's national rise to prominence as a widow. Nonetheless, this analysis compares the two women in the larger context of post-bellum American society. Their trajectories as widows could not have been more different, and this, I would argue, has much to do with their wartime associations. Julia Grant was a popular First Lady associated with the Union victory of the Civil War, rather than the tragic losses Lincoln evoked (especially after her husband was assassinated). Additionally, Grant's unabashed slave ownership and proud claims to southernness (though she was from the border state of Missouri), as well as her "Queen Mother" persona in her own widowhood gave her much the same prestige as Davis enjoyed in her later years (Hendricks 148).

${ }^{16}$ Because she had male relatives fighting for the Confederacy, Mary Lincoln was accused while in the White House of being a southern spy, so her western background did nothing to shelter her from rumors of treason for her southern ties (Hendricks 127-8)

${ }^{17}$ Notably, this same newspaper had published Lincoln's letters regarding the "Old Clothes Scandal."
} 
writers (Cashin 268-9). As an independent woman and a writer, Davis distinguished herself as self-assured and strong. At the same time, in performing an innocuous identity as an old fashioned and mannered woman, emphasizing the special wisdom that southerners from her generation had gleaned from the Spartan years of the Confederacy, Davis was able to maintain her agency without threatening the Victorian social order of the U.S.

A letter discovered in 1937 by the WPA Writers' Project Historical Inventory is presumably a snapshot of Varina Davis's life in the south as the war neared its conclusion. Though never published in her lifetime, the missive was likely intended for publication, as many of Davis's letters were. The piece contains titled subsections that describe different themes: "Good conduct of the negroes," describes the shift in productivity of the southern plantations as slave labor significantly dwindled, in spite of Davis's assertions of overwhelming loyalty from slaves: "their cause was a powerful testimonial to the lifelong kind and just exercise of their masters' power over them," she states. Davis also highlights other aspects of wartime southern culture. "How the women faced the war situation," "How clothing was contrived," "How we lighted our homes," "Our coffee and tea," and "Reading matter and starvation parties" fill the remainder of the letter. Focusing on the day to day activities of a lost culture under siege, the letter makes no statement about the politics of the war, but instead highlights the sacrifices of southerners for their Cause, offering precious glimpses of a mythical bygone time and place and emphasizing the strength and loyalty of the women who maintained the domestic infrastructure for their brave husbands and sons (V. Davis).

Varina Davis embodied of her role as an antebellum icon in other ways: in 
etiquette columns in the World, she discussed the nature of femininity in quaint terms, using language that was atypically decorous, even for the Victorian era. While she was widely revered as an endearing icon of the "Old South," the Widow Davis was also sometimes characterized as borderline archaic in her adherence to southern antebellum views and etiquette, a charge that nonetheless framed her widowhood as nonthreatening and perhaps charming. An 1893 newspaper article quotes the widow on the subject of women's suffrage. In it, she describes herself as an "old fashioned" woman and expresses her views about the "God-given" role of the fairer sex and her concerns about how suffrage for women might threaten their rights to be protected by men ("Mrs. Jefferson Davis and Kate Field" 3). A December 11, 1902 advertisement for "Christmas Stories Told By Great People” lists Mrs. Jefferson Davis alongside southern folk writer Joel Chandler Harris as one of the featured authors for an upcoming special Christmas "Number" to be published by the World the following Sunday ("The Sunday World's" 8). While her public persona - like the massively popular characters of Harris's fictionalized slave society—occasionally bordered on caricature, it nonetheless allowed Davis to gain favor with a population who much preferred these relics of a unified past to the fragmentation and anxiety of the real world at the turn of the century.

In Davis's insistence on wearing mourning dress until her death, she became an image of grief and remembrance that exemplified the same kind of sentimental, yet restrained bourgeois Victorian memorial movement taking over Europe and the US, with which the widowhood of Queen Victoria is often associated, and for which she came to be seen as an icon of feminine nobility, symbolized most obviously through her lifelong widowhood and mourning dress (Rappaport 407). While Mary Todd Lincoln was seen as 
excessive in her grief for wearing widow's weeds for the 17 years after her husband's death until her own demise, (Bach 26) the widow's weeds worn by Davis and Queen Victoria for the duration of their own lives established certain social signifiers that Lincoln was unable to effectively appropriate (Baker 193). In her sacrificial, yet emotionally restrained attitude toward her departed husband, Davis embraced the image of the loyal, selfless widow that eventually won Victoria widespread approval, while Lincoln's spectacles of emotion disconcerted the public and made her look melodramatic and vulgar - a low-brow version of the sentimental movement that so plagued class lines in the Victorian era (Halttunen 97).

Biographer Joan Cashin describes the Widow Davis as a quintessentially New York character, waking late in the day, spending hours receiving guests and writing letters, going out for late-afternoon carriage rides, and visiting her multitudes of female friends who also lived in the city. New York was where Davis felt most at home, but paradoxically, her inclusion in New York society was largely due to her position as an icon of the Old South. An incident in her widowhood that clearly reveals Davis's importance to the memorial culture of the nation was in her election to the Daughters of 1812. The society was formed in 1892 and she was elected as its first Vice President. Established by a former Confederate wife, the names on the organization's board reflect a tendency among southerners to mythologize and memorialize the past, but also to selfconsciously attach themselves to national history in addition to the "Lost Cause" southern nationalist mythology (“This Week’s News”).

The connection between southern women and national memory is exemplified in Varina Davis's continued outreach to northerners, but it also demonstrates the northern 
embrace of southernness and their devotion to the myths that southerners were increasingly inclined to create around themselves. Davis adopted a public diplomacy toward the North in the late 1880s and early 1890s, offering various olive branches to the Union on behalf of the South. In several instances, she made gifts of her late husband's belongings to black acquaintances of his who were still alive. A short mention in the black newspaper, The Plaindealer of Detroit, dated August 7, 1891, for instance, describes a gift the widow made to a "Frederic B. McGinnis, a well-known colored man," of "a handsome osage orange-wood cane." The gift is reported to be "a bequest from the late president of the confederate states" ("A Variety of Things" 2).

These social encounters and bequests of Davis, as the Confederacy's only First Lady, were widely publicized and helped to promote the notion that the nation was making important strides in closing the divides between the two sides of the war. In the later years of her life, she became connected with Julia Grant - the wife of the famous Union General and 18th President Ulysses S. Grant. Davis and Grant were occasionally mentioned in the news together and they are known to have corresponded through letters. When they had their first meeting — both already widows - the event was covered in newspapers across the country. The Washington Bee reported in April of 1893 that the women were to meet at West Point. Later in the year, the same newspaper reported that, "Mrs. U.S. Grant and Mrs. Jefferson Davis [...] have apparently struck up a friendship. The West Point military authorities will not officially recognize Mrs. Davis, but she will receive social courtesies" ("Mrs. Davis to Meet" 4). In 1901, Davis actually published a piece in the World in honor of Grant, the same man who had accepted the surrender of the revered Confederate General Robert E. Lee. The piece, titled "The Humanity of 
Grant," extols the virtues of Grant, offering Davis's opinion “that he was a decent person and a "great man"' (Cashin 298). Davis figured the imagined civilization of the Old South for northerners and in her conscious outreach to icons of the Union, she provided symbolic gestures of reconciliation for the country.

In a marked contrast to the press's sensationalizing of Mary Lincoln as excessive and crude, a newspaper piece from April 1903 that was reprinted in various publications around the nation paints Davis as a "modest" icon of gentility and wisdom. The article is subtitled, "Widow of Confederate President Lives in a Modest Way in a New York Family Hotel.” The piece describes an average day in the life of the elderly widow, who has moved to New York for "economic reasons." Presenting Davis as a charming vestige of a bygone era, the article mentions that she uses an old-fashioned gold and tortoise shell cane, "as people did 100 years ago," and that she "does not have to visit, as her friends pay court to her as if she were a royal personage." It also describes "the long file of admiring women who call," remarking that, "there are as many Northerners as women from South of the Mason Dixon line" who come have an audience with the former First Lady of the Confederacy. The story makes special note of Davis's keen mental faculties as "a noted conversationalist," who "holds the attention of everyone without an effort" ("Mrs. Jefferson Davis. Widow of"), presenting a stabilizing image of the widow as a treasured cultural repository of aristocratic, grandmotherly wisdom.

Upon Davis's death in 1906 at the Majestic Hotel, where she had been living for a number of years, the importance of the Confederate First Lady becomes more evident. In The New York Times, her obituary was a biographical memorial piece, presenting Mrs. Davis as a figure of dignity, intelligence, and strength. The obituary notes that, "Mrs. 
Joseph Pulitzer of 7 East Seventy-third Street, also a relative" was present at Davis's deathbed, alongside other family and friends. Connecting Davis to the Pulitzer family connected her to the city of New York, instilling a memory of her as belonging to the north as much as the south. The obituary lauds Davis in a subtitle as a "Devoted Wife": "She Was Her Husband's Constant Companion and Advisor." Though the north claimed Davis as one of its own, interestingly, the Times obituary admires how Davis's loyalty to her husband was intertwined with her loyalty to the Confederacy:

[U]ntil Jefferson Davis died in New Orleans in 1889, his wife was with him, in peace and war. As devoted to the Confederate cause as her husband himself, she could hardly be persuaded to leave Richmond when Grant began to close in around it in 1865. Mrs. Jefferson Davis was her husband's constant assistant and adviser. ("Mrs. Jefferson Davis Dead") The obituary at once praises Davis's loyalty to her southern roots while offering admiring anecdotes and details that elaborate on her northern education, northern political leanings, and familial ties to the northeastern upper class social sphere. The piece also references Davis's other northern ties, including her grandfather's New Jersey governorship and her schooling in Philadelphia. Additionally, the write-up attributes Davis's late husband's success in part to the steadfastness and devotion of his noble wife, remarking that "[i]n the preparation of some of his ablest speeches, it is said, his wife rendered him valuable assistance" ("Mrs. Jefferson Davis Dead").

If it is traditionally the female role to emote-as Sandra Gilbert discusses in her examination of modern mourning practices - and the male role to eulogize, "to politicize grief in public eulogies, or [...] in ceremonial elegies," then the Widow Lincoln's over- 
emotional reaction in the wake of the nation's loss rendered her perhaps too female for the changing times - a physically embodied reminder of sorrow and brokenness.

Alternately, the Widow Davis, unlike Lincoln, adopted the role of eulogizing her husband, even before his death, penning letters on his behalf and publishing newspaper accounts of her efforts to have him freed from prison ("Miles" 3). Monumentalizing Davis as a figure of grace and transcendence in her feminine humanity, in spite of her ties to the rebel Confederacy, her New York obituary also notes that

[i]n her memoir of her husband Mrs. Davis tells of their life in Richmond during the great war. She tells how the flag captured from the Merrimac was brought to her, and how the discovery that it was damp with blood made "her sick and sorrowful over the dead and dying of both sections." (“Mrs. Jefferson Davis Dead")

Even in her death, Davis was cast as a representation of wholeness and redemption, a figure who served the public's immediate needs. Unlike the public treatment of Mrs. Lincoln, southerners and northerners alike supported Davis and embraced her as one of their own. While she was criticized at times, Davis never experienced the ridicule and rejection faced by Mary Todd Lincoln (Burns 28). In a sense, perhaps Davis did little more than fleetingly assuage a national yearning for escape, as her legacy has been largely forgotten by mainstream culture in the U.S. in the generations since her death.

\section{7. "People Like to Believe in Fairy Tales": Jackie Curates Camelot}

Print media popularized the image of a genteel Varina Davis with her civilized antebellum values as a metonym for the wholeness of the nation while promoting the exclusion of a shamed, unstable Mary Lincoln, who figured the fractured Union, but who 
also reminded Americans of the reality of democracy as complicated, contradictory, and ugly. In the twentieth and twenty-first centuries, as methods for inscribing political ideology have proliferated across innumerable communicative platforms, acts of sartorial image-making itself have seemed to become performances of duty for celebrities and politicians. The mass marketing of, and by, the First Lady in the interest of supporting the image of Presidential power by staging her as the "woman behind the man" highlights her position as a representative body whose static hierarchical position and public image is dependent upon adherence to specific social codes that lend an air of tradition to the position. ${ }^{18}$ "This mix of marketing, mainstreaming, and popularizing but also denigrating and silencing feminism," writes Zillah Eisenstein, "blurs the lines between using women as icons for the market and encoding feminist claims [...] mass marketing absorbs, publicizes, normalizes, depoliticizes and disciplines all at the same time" (99). The mediating power of mass communication draws attention to and fosters dependence upon itself as a principle authority in shaping public perception, and the widespread acceptance of the position of First Lady as a managed and managing social force via such platforms reflects her ongoing political value as a commodity in the market exchange of social

\footnotetext{
${ }^{18}$ Both Eisenstein and Rubenstein have discussed the position of the First Lady and its fraught dynamic with public expectations and gender performance, notable in the ongoing public fascination with Hillary Clinton's sartorial image both during her tenure as First Lady and throughout her own political career. Clinton's self-conscious adoption of the pantsuit (per her Twitter description, for instance: "Wife, mom, grandma, women+kids advocate, FLOTUS, Senator, SecState, hair icon, pantsuit aficionado, 2016 presidential candidate" [@HillaryClinton]) in recent years is her latest effort to manage public expectation by figuring femininity as it intersects with politics in a performance that inevitably exposes, in Rubenstein's words, the "latent instabilities of all gender identity" (141). Her position as First Lady and the critique of her femininity during that time has arguably affected her subsequent gender performances in significant ways that have characterized her political persona as increasingly "inauthentic." The complexity of Clinton's public image emphasizes my point that as much as the First Lady's performance of her role matters, the public expectation that she perform these roles with an air of authenticity is also hinged upon a keen awareness of politics and gender as social dynamics whose intersections must be managed appropriately. Authenticity is valued as another aspect of performance, rather than an expression of sincerity. Howard Zinn's concern with the commonality of citizens operating not as democratic subjects, but rather as armchair politicians points, as well, to the successful mediation of politics through representative figures like the First Lady (and, of course, the President) (Zinn).
} 
control and capitalist growth.

While the role has been formalized to some degree by the press, historical precedent, and most obviously through the creation of the Office of the First Lady ("Executive Office of the President"), the function of the First Lady is continually being reshaped by the succession of women who have inhabited the position and their responsiveness to the societies they represent. At times, the image of the First Lady has been arguably as important for the image of the Presidency and the nation as the President himself has been. Diane Rubenstein notes that the facets of a First Lady's tenure that eventually come to define her in the historical imagination have everything to do with her embodied condition as an object of "scopic fascination" in the media: "For First Ladies since Martha Washington," she writes, "have set a 'presidential tone' and have been conveyed by a lexical shorthand that links social cause or public interest with some sort of Barthesian 'little real,' biographeme, corporeal, or sartorial metonym," like Jackie Kennedy’s pillbox hat, or Nancy Reagan's infamous “Just Say No” campaign (128). As a surrogate for her husband as well as a cipher for coding traditionally "feminine" aspects of the citizenry, the First Lady is at once everyone and no one, and the negotiation of this position is tied intimately to her performance of gender, race, and class, and the authenticity with which she performs these social roles.

Jackie, a 2016 biopic directed by Pablo Larraín, posits the public success or failure of the First Lady as largely dependent upon the fitness of the woman herself, and he manifests this perspective through a fictional glimpse into the "behind the scenes" world of Jacqueline Kennedy in the hours and days following the assassination of her husband. Portraying his titular character as a new widow actively seeking a spotlight for 
her grief, Larraín presents Jackie as a sad yet shrewd figure who believes that if she injects the great legacy of her husband into the imagination of the public, she will survive the loss, as well. The film blends historical details with Larraín's hypothesis of what he imagines Jackie did behind closed doors as she processed her situation, presenting a vision of the First Lady as one of the most intuitive image-makers of the twentieth century.

The grief Larraín invites viewers to share is not the grief of a wife, but the grief of the First Lady as she figured the sorrow of the nation. Larraín states that in Jackie's performance of public grief, she "became a mother - a big mother — not just for her own children or for this country but as someone who could bring people together and open a huge umbrella and protect everyone" (Formo). Jackie's success in ensuring the legacy of her husband and her own name is in her intuitive feminine understanding of how to construct a mythical world and invite the public into it. In the world Jackie constructs, however, the public is allowed to look, but not to touch. The film characterizes Jackie as if she is the curator of a museum facing an aesthetic challenge, and her graceful service to the beauty and sacredness of the President's death as the ultimate sacrifice projects Jackie herself as an iconic figure. The film taps into this iconography of Jackie by meticulously recreating her blood-stained dress, her 1961 television tour, and JFK's epic funeral procession, using the biopic as a meta-mythological construction of Jackie as the masterful symbol of historical political power, a kind of "woman behind the legend" legend.

Up against the male-dominated world of the President's colleagues, Jackie's intuition is cast as her special wild card against the commonsense logic of the patriarchal 
status quo. Noah Oppenheim, who wrote the film, explained in interviews that he was interested in showing this side of Jackie to the public because of "the great untold story" of her role in promoting Camelot as the metaphor for the Kennedy Presidency. "Most of the time," he says, "anything written about her is focused on her beauty and sense of style and complicated marriage. She had an intuitive appreciation for the power of the visual, for the power of TV, and that iconography influences politics and the way people perceive politicians and events" (Thompson). Oppenheim admiringly cites Jackie's 1961 televised tour of the White House as a crucial example of the First Lady's genius in "craft[ing] a certain story that she wanted to tell—about her, and her husband, and their place in American history [...] creating this illusion of transparency, and talking about the historical artifacts that she had surrounded herself with and the men and women who had lived in that house before them," referring to this kind of staging as a "modern idea, and a modern performance" (Wilkinson).

Actress Natalie Portman plays Jackie, and her performativity as Jackie performing the role of First Lady is emphasized through tight framing and sequence shots that pan at the pace of her movements, effecting a voyeuristic audience experience that invites us to judge both Jackie and Portman's performances of their respective roles. These selfconscious tropes of performance and judgment are injected into the narrative via the camera techniques, but also because of the film's hyper-focus on re-imagining some of the most famous public broadcasts of Jackie in her early widowhood, both as they were broadcast and, crucially, as they were produced. The film reconstructs the 1961 televised White House tour as a "better days" reference against the funeral, the dramatic irony of which is predicated upon the audience's intimate connection to John F. Kennedy's 
assassination.

The scene features Jacqueline Kennedy as the First Lady par excellence, an expert in the history of the Presidential mansion and a curator of the material objects it houses as sacred objects of nation history. Portman as Jackie walks stiffly in an exacting recreation of the mannerisms of the First Lady during a tense sequence shot that silently surveys her as she passes before a series of black and white cameras. Jackie, as we watch her, enters and exits the frames of the black and white broadcast, shifting between the gray-scale televised Jackie and the real-life color version that is being filmed. The meta-narrative of Jackie's legend-making, a fragile and brave actress in a larger-than-life theater, is emphasized when the full-color version of Larraín's Jackie nervously looks out into the blackness behind the daunting array of cameras in search of some cue or direction. An over the shoulder shot brings Jackie's best friend and personal assistant into focus as she bestows a comforting smile upon the First Lady while she points at her encouraging smile, gesturing for Jackie to do the same, to smile for the cameras.

In painstakingly recreating clothing, hair, sets, and televised events like the shooting, the funeral, and the famous White House tour, Larraín offers a close-up view of Jackie as a public figure, but does not portray an interior exploration of her personal grief except as a shared experience of the loss for the nation. The majority of the film presents Jackie in isolated frames or in long shots where she walks alone. Even scenes that frame Jackie with other characters situate her as a segregated force of will, separated from the people with whom she interacts by some invisible internal barrier to which we are not privy. The film's concern with individual agency in the construction of public history conjoins with the imagery of intimacy as a production, as the experiences of Jackie's 
personal pride and grief alike become opportunities for national myth making - a gift she gives to herself and to the American people. A lengthy fictionalized scene that captures the emotional experience of the tragedy for the First Lady features Jackie attempting to somehow hold on to the remnants of what "should-have-been" her idyllic life as the wife of the President, trying on a succession of formal gowns that she will never wear while getting progressively more drunk, parading alone in her bedroom suite as she seeks some form of expression for her own Cause. As the score from the musical Camelot plays in the background, the scene suggests that Jackie's solitary foray into what-should-havebeen germinated the seeds of the Camelot mythology.

The planting of the Camelot seed into the public imagination is framed with an interview of Jackie by an unnamed male reporter. The interview takes place shortly after JFK's funeral, and it serves as a meta-commentary on the meaning of the President's death and his legacy as it is being shaped, in part, by the interview itself. The trope of authenticity as performance is clear throughout as Jackie and the reporter engage in a taut and self-conscious dissection of the funeral procession and the widow's display of grief as it figured public sentiment. Jackie's neurotic self-censorship and gut-level decisionmaking during the interview and throughout the film's other key scenes emphasize the First Lady as shaped by, and shaping Presidential legacy in American history; the film makes repeated references to Jackie as informed and educated by the successes and failures of the Abraham Lincoln Presidency and his First Lady's widowhood. The link between the Kennedy legacy and the Lincoln legacy works as both an etiquette manual and morality tale for Jackie and for her brother-in-law, Robert Kennedy, both of whom believe that JFK was the rightful inheritor of a legacy of greatness like the abolition of 
slavery had afforded Lincoln. They sorely lament the beautiful society that JFK never got a chance to give to the nation. While Jackie pushes in various ways for a funeral that will generate a Lincoln-Kennedy connection in the public eye, she simultaneously undertakes to avoid the fate of Lincoln's sad wife.

The sorry story of Mary Lincoln comes up multiple times in the film, Jackie offering her up as a horrifying example of public widowhood gone wrong. Alternately, she uses Abraham Lincoln's funeral procession to model her own funeral parade for the fallen President, appalled at the notion that no one seems to care as much as she for the image of greatness that the nation should project via the funeral of their leader. The film characterizes the famous widow as at once vulnerable and anguished, but above all, dignified to the point of defiance, insistent that her husband be interred and honored with the utmost reverence. Throughout the film, we see Jackie attempting to maintain an air of passivity and demure acquiescence and finding herself left out of decisions to which she believes she should have primacy.

Forced by obtuse and willful men who claim to know better than she what is appropriate, Jackie is repeatedly forced to plainly and gracelessly demand what she wants: a royal legacy, a spectacular funeral led by horses, an open-air procession, a grave at Arlington National Cemetery (and not in the Boston Kennedy family plot). It is not until the end of the film that we see Jackie pick up the telephone to catch the reporterwho has been passive aggressive and apathetic in response to her coy suggestions that her husband was deserving of legendary status in the public memory — before he finishes writing the article, plainly directing him to describe the Presidency of JFK as Camelot, which he does. What makes Jackie especially useful for this chapter is that that the 
decisions she makes, under duress, shape history quite plainly. Her fictionalized world of Camelot, the tragic "should-have-been" becomes the future of American history even in its own present moment; Camelot is the memory implanted into the public psyche, as if it had been real. The film suggests that were it not for the last-minute instinctive decisions of Jackie, the future might have been an entirely different place.

Desperately alone in her own particular experience, a woman attempting to find solace amidst a masculine cohort of the most powerful decision-makers in the nation, Jackie ultimately transcends her messy embodiment as a confused and insecure new widow because of the brilliant force of her logic that "people like to believe in fairy tales," and her iron will to ensure that this logic drives the imagery and rhetoric surrounding her husband's death. Although Jackie's interior life remains a mystery, her dogmatic perspective on the significance of her role drives the plot. Contemporary reactions of the public do not enter the milieu of Jackie at all, except as an intellectual projection of the widow's anxiety against the political reasoning of the men who run things.

The film forecloses any impression that Jackie is a reflection of culture by repeatedly showing her apart from society, a watcher of culture, a critic. Her struggle with public opinion is manifested as a binary tension between female intuition versus male intellect, with intuition ultimately winning out. Jackie's endowment of the myth of Camelot, along with her didactic emphasis on the material history of the White House are endowed to the public, and in her patronage to public aesthetics, she is cast as something transcendent and iconic, an ideal First Lady and an ideal citizen. As a disembodied ideological abstraction, Jackie's figuring of the "airy conditions" of necro citizenship is 
poignantly illustrated in the film's final scene. During a voiceover narration (presumably from her earlier interview), she discusses her role in history and her belief in the importance of remembrance, expressing her fear that she will be forgotten. As the monologue ends, Jackie's cab stops at a light. She looks out the window and watches mannequins dressed to look exactly like her, as they are unloaded before the display window of a department store.

\section{Slippery "Should-Have-Beens"}

The appeal of the epic mythology exemplified in the Lost Cause south and the Kennedys as Camelot relies upon a version of representative democracy that privileges the imagined national community as a stable, idealized civilization, often figured in figures like the President or other political celebrities who manage to get the timing and tone just right. Larraín's Jackie exemplifies the nostalgic insistence with which such images return to the public consciousness. The ideological pull of the romantic "shouldhave-been," as it has functioned to assuage collective national traumas and disappointments, like many coping mechanisms, offers immediate relief, but eventually requires recalibration or replacement, as its ability to resolve fundamental tensions cannot be maintained on image alone. Lauren Berlant discusses the consequences of this mediation by representative bodies as it controls the citizenry's understanding of its own power as a democratic collective. While such figurings "are not official propaganda for a political good life," they nonetheless "generate reliance on media so that people come to define collective experience as a dense web of mediatized events" ("Uncle Sam"157). This version of democracy as it gets mediated through representative public figures becomes "preferable to a reality in which ordinary human relations seem less worth 
investing in [...] It is as though an aesthetic of fascination or absorption by the image is the fulfillment of the promise of belonging that an icon holds out" (157-8).

While the public attachment and lingering nostalgia toward Davis and Jackie as objects of desire can function to create communal relations and meaningful surrogations, this attachment nonetheless perpetuates ongoing disappointment and discord in societal experiences, especially where the status quo is disrupted and the desire-based schema is threatened. Berlant calls this cycle of desire and dejection "cruel optimism": "What is cruel about these attachments, and not merely inconvenient or tragic, is that the subjects who have $x$ in their lives might not well endure the loss of their object or scene of desire, even though its presence threatens their well-being" (“Cruel Optimism” 21). Such mythical historical constructions and political projections must undergo continual revisions and justifications, as in Jackie, where the First Lady as iconic image-maker of the iconic First Lady is justified via the same circular "scopic fascination" that attended the original — in fact, now rendered almost exclusively as image, a curated, "behind the scenes" collection themed by public performances.

Devoid of the inflection of history, culture, or society altering the pure transmission of this re-imagined replica, the First Lady is as a mannequin, posing from a staged and untouchable vignette, affecting postures that generate collective desire; we want what she wants. The tendency for such iconic and fixed constructions of order to substitute in American society for active and participatory democracy reflects "a relation of attachment to compromised conditions of possibility" in the nation (Berlant, "Cruel Optimism" 21). Such mediations of democracy through representative figures profoundly affects collective historical memory, but perhaps more importantly, it alters the 
"conditions of possibility." As the imagined and re-imagined past inevitably necessitates a reconstruction of the imagined future, the material conditions of the present moment are forgotten along with the rejected versions of the past, which are exiled from their social, cultural, and historical communities. Consequently, the future, based not on the present moment, but on an imagined past, is thus limited to a perpetuation of predictability with endless variations on the same themes. 


\section{CHAPTER TWO}

\section{FRONTIER FUTURES: PROGRESS, PURITY, AND PENANCE ON THE DUST}

\section{BOWL PLAINS}

"It was going to be another one of them dirty dusters [...] It wasn't even our dirt. We never could figure out whose dirt it was. It's not our dirt."

--Betty Fisher Williams (Stallings 17)

Analyzing Varina Davis as an embodiment of an imagined past and exploring how she functioned as a symbol in the Reconstruction Era offers perspective into some of the underlying anxieties that accompanied the turn of the twentieth century, as the devastating memories of the Civil War faded. Such an analysis also offers a framework for thinking through the value of imagined histories. American Progressives accumulated immense power through the late nineteenth and early twentieth centuries, and their synthesis of Christian morality and unapologetic global conquest was facilitated through a continued emphasis on the frontier, which they deployed as a key metaphor for American history, interjecting the exceptionalism of manifest destiny into the imperialist agendas of the United States. The push of the U.S. ever further into the global arena in the twentieth century altered the composition of the "character" of America and its various representative figures, as they took on a more prominent role on the international stage. In the infamous figure of Historian Frederick Jackson Turner's mythological American pioneer, the imagined past of the nation became entwined with its imagined future. As the pioneer character gained popularity in mainstream culture, the frontiersman 
became a key symbol for the nation's future, even in its service as a historical tool to explain the past. ${ }^{19}$

This chapter explores the function of Dust Bowl as a disruption in the chronicle of progress in U.S. history and explores the significance of this disruption for the processes that various authorities have undertaken in seeking to shape the future of the nation. Alongside the Great Depression, the catastrophic dust storms in the Great Plains, which — like the Depression— persisted through almost the entire decade of the 1930s, triggered a state of unease about the expansionist fervor that had been taking over public discourse for a generation. As the storms assaulted the Plains for years on end with little respite, those living in afflicted states became increasingly convinced that the incessant clouds of dust looming over the region were the harbingers of God's wrath, punishing them for their overambition and hubris. Particularly after April 14, 1935, also known as "Black Sunday," when one of the most terrifying dust storms of the decade ravaged the Plains, the future-oriented frontier confidence that had led to a huge population surge in the region during the Progressive Era was increasingly supplanted by apocalyptic rhetoric that featured a sinful nation and a punishing Creator. The fear and shame expressed in the apocalyptic anxiety of the Dust Bowl era were exacerbated by, and reflected, the complicated aftermath of Progressive Era policies and cultural changes that had refashioned the moral and social landscape of national citizenship and cast the U.S. as an imperialist power.

\footnotetext{
${ }^{19}$ While pioneer and frontiersman are not necessarily synonymous concepts, I use the terms synonymously as useful ways to conceive of the multi-faceted incarnations of the Turnerian frontier "American." I also use other names to convey this idea, such as adventurer, conqueror, or backwoodsman. Likewise, these terms reflect the same kinds of ideas that are woven tightly into the fabric of the frontier cultural construction.
} 
A brief analysis of Frederick Jackson Turner's 1893 frontier thesis situates the period of the Dust Bowl as intimately linked to one of the most influential theories in the study of American history. Progressive Era frontier philosophy relied upon a concept of American identity that was exemplified in the Turner thesis as a major factor in the policies of the federal government in its settlement of the Great Plains region. In contextualizing the Dust Bowl through the Turner thesis and using this context to study the perspectives of those who experienced the disaster and attempted to survive on the dust of an eroded landscape, the real-life Turnerian character of President Theodore Roosevelt and his Progressive capitalist moralizing reveals the symbolic significance of the pioneer. As a precursor to the current global era of American conquest and its representative figures, Roosevelt's staging of himself and the nation as trailblazing an exceptional historical path exemplifies the reliance of this rhetoric upon righteous convictions. The lasting impact of the Progressive Era frontier perspective is vividly illustrated in the 2014 Dust Bowl film, Interstellar, the analysis of which provides a way to investigate the United States' ongoing national relationship with the myth of the frontier future and its position in our understanding of disaster-making policies. The catastrophe of the Dust Bowl reveals a widespread moral ambivalence about the potential of a country that had begun to remake itself in the image of the old world, even as it declared itself to be opposed to old world values. ${ }^{20}$

\footnotetext{
${ }^{20}$ While it stands to reason that a variety of interpretations of "The American" character (eg: Franklin, Tocqueville, Jefferson, Trollope, Dickens, Twain) existed in public discourse at this time, I focus this chapter on the narratives engendered by the Turner frontier thesis as a key factor in the construction of national character, because the thesis reflects the values of Turner's society, and his articulation of those values had a significant impact on the intellectual and political conversations of the time. Importantly, Turner's argument hinges on a binary opposition between Europe and America, making explicit distinctions between the eastern regions of the U.S. as more European in character, with the western areas evolving into different, new, and not-European places.
} 


\section{Raised by Wolves: Disclaiming the Motherland}

The 1784 narrative of Daniel Boone's settlement of Kentucky, written by John Filson, is a kind of early template for mythologizing American expansionism. Embodied in the life of the adventurous fur trader, war hero, Indian killer, and land speculator who blazed early trails through the wilderness on behalf of America, Boone's brand of pioneering was characterized as distinct from the refined Anglo model of eastern settlements. Discussing the resurgence of the Boone legend in the mid-nineteenth century and situating the popularity of the figure of the frontiersman as the new alternative for masculine cultural affiliation in middle-class society, Daniel J. Herman refers to Boone as "the first mass culture hero" (432). Herman draws connections between characterizations of Boone as a powerful figure of masculine authority in his own time, and again at the turn of the nineteenth century, and still again in later incarnations in American popular culture, all the way to Theodore Roosevelt's penchant for buckskin jackets (454). David Wrobel analyzes the angst that the "closing" of the frontier had on the collective psyche of Americans at the turn of the century, in what he calls a "postfrontier anxiety" that resulted from losing the sense of identity and history the myth of the frontier had lent to the nation. Nostalgia for the frontier has served as a coping mechanism for this anxiety and has often re-entered popular culture, as the fascination for the wilderness and with those who settled the west has not abated, even in recent years (Wrobel 103-6). The enduring popularity of the pioneer is evident in the scores of frontier television shows, notably those of the 1950s and '60s, which accompanied John F. Kennedy's “New 
Frontier" platform $(89-96,145)$, and even now, a number of films and television shows concern themselves with early American trailblazing. ${ }^{.21}$

Though Boone was well known to influential circles during his own lifetime, Herman points out that he was largely unknown to the larger public until Filson's history was written. Subsequent biographies published throughout the next two centuries further catapulted the Boone story into the mainstream, with Boone eventually becoming a household name and attaining a near legendary status in popular culture by the twentieth century (Herman 435). With the 1833 publication of Timothy Flint's Biographical Memoir of Daniel Boone, the First Settler of Kentucky — published after Daniel Boone died in 1820 - the famous adventurer was resurrected in popular imagination and reanimated as the heroic backwoodsman and hunter, a hero who rejected the corrupting influence of civilization in exchange for a life of conquest and masculinity (430). "[I]t was no accident," Herman writes, "that Boone's popularity peaked at a time when most Americans found it unnecessary to battle cruel beasts or brave trackless wilds. Indeed, the virtues and aphorisms of Boone sometimes served as oblique commentaries on life in the city" (436). In the late nineteenth century, as the eastern United States grew into a landscape of cultivated farms and teeming urban hubs, changing ideals of manhood reduced the Jeffersonian land-owning yeoman farmer to a relic of the European-shaped past that was typically associated with the east, while "American" masculinity became synonymous with the wildernesses of the western U.S. (440). By the time the Mexican-

\footnotetext{
${ }^{21}$ This chapter closes with a discussion of current representations of the frontier in the 2014 blockbuster film, Interstellar, but other treatments of the theme have made their way into Hollywood since then, notably the Oscar-nominated 2015 film, The Revenant, which is loosely based on the harrowing and heroic near-death experiences of Hugh Glass, a frontiersman and trapper in the Dakota territory in the early nineteenth century.
} 
American War had stretched the vista of the U.S. from one coast to the other, the frontiersman had become the symbol of American power.

The pioneer myth that drove Teddy Roosevelt's Progressive Era, and which beckoned to easterners and those of the "old world" to settle out west and stake a claim in the freedom of the American frontier called upon an iconographic concept of Americanness that figures like Boone represented in the public imagination. ${ }^{22}$ Linked to the founding fathers, Boone's status as a man of the wilderness allowed him to serve as a surrogate for epic histories that the nation lacked. ${ }^{23}$ Boone was actually likened to a Romulus figure for the country, ${ }^{24}$ and in this connection between America and the nearmagical heroism of the frontiersman during the nineteenth century, the country found a retooled origin myth for itself that suited the times (Herman 430).

Through its association with the untamed wilderness, the Boone legend imparted a primordial sense of history to the land and its inhabitants, disregarding (perhaps transcending) the temporal limitations of traditional U.S. history, and providing counterclaims to suggestions of a status as a historical subordinate to England. ${ }^{25}$ Herman writes that the stories of Boone that spread through popular culture in the nineteenth century and beyond "tied together middle-class masculinity and middle-class notions of empire in a single discourse of "indigenous" identity" (432). Though the symbol of the

\footnotetext{
${ }^{22}$ Roosevelt was influenced by the figure of Boone long before he became a global political player. Prior to his Presidency, he founded The Boone and Crockett Club, which still exists today and which focuses on settlement and conservation of wildlife in the west. As a historican, Roosevelt's interest was similarly oriented: in 1894, Roosevelt's multi-volume Winning of the West was published, chronicling the history of American westward expansion from Boone to Crockett (Whitelaw 64; Slotkin 37).

${ }^{23}$ Obituaries upon the death of Boone emphasized his role in staking out new lands for his fellow Americans to inhabit, much like the early Greek and Roman epic heroes: "He was one of the few men of our country whose enterprise led him to search into the wilderness for the best tracts of land for man to inhabit." [Death Notice, Daniel Boone]. Rhode-Island American. 10 Nov. 1820

24 "This same backwoodsman should be ranked above Romulus or any other founder to which nations look with reverence." "Daniel Boone." New-Bedford Mercury. 11 April 1834.

${ }^{25}$ This impulse to generate historical claims against charges of barbarism is discussed in chapter one.
} 
frontier and frontiersman were already entrenched in a variety of historical treatments and were becoming familiar figures in the socio-cultural composition of the United States, Frederick Jackson Turner's famous essay, “The Significance of the Frontier in American History," integrated various manifestations of this pioneer epic into one compelling chronicle of American history. In July 1893, Turner presented his thesis at the World's Columbian Exposition in Chicago, positing the frontiersman as a quintessential national character and legitimating the concept of the frontiersman as distinctly American.

\section{2. "New World" History: Mapping the Origin of the American Man}

"The frontier is the line of most rapid and effective Americanization," Turner asserts, promoting the notion that the difference between the people of America and the people of Europe is not necessarily a result of the socioeconomic class of the citizenry, or of the ancestry of those who settled, but a difference that was enacted from the outside, by the land itself (Turner 4). By 1893, the difference between Europeans and Americans, Turner states, has become a fundamental difference, shaped by the endless expansion of frontiersmen and their devotion to building a democratic nation. His thesis asserts that the U.S., because of its particular geography and "free" land, has opened opportunities for success that Europe had long since closed off to its common men. ${ }^{26}$ He poses a unique perspective in analyzing the history of the nation by examining it spatially, from east to west, describing the eastern portions of the nation as markedly similar to Europe in governance, infrastructure, and culture. In conquering and settling the west, according to his analysis, the pioneer was able to move steadily away from the European influences that defined the eastern U.S. As the extraordinary land, its animals and resources, and

\footnotetext{
${ }^{26}$ My use of the male pronoun in referring to American settlers in the discussion of the Turner thesis is in keeping with Turner's own construction of the "American" as a decidedly male character and in his use of the male pronoun throughout his essay.
} 
encounters with the native inhabitants began to transform the pioneer character into a new type altogether - a synthesis of wilderness and civilization - the ultimate representative of American democracy was born in, and through, the frontier. ${ }^{27}$

The endless potential of America was at the root of Turner's thesis - an extension, in many ways, of the ideology that arose in the mid nineteenth century concerning the notion of manifest destiny: "What the Meditterranean Sea was to the Greeks," Turner writes, "breaking the bond of custom, offering new experiences, calling out new institutions and activities, that, and more, the ever retreating frontier has been to the United States" (38). Turner's claim that America is moving along a historical trajectory that parallels the rise of ancient Greece is important to note, especially when he juxtaposes it with a backward-looking reference to the "retreating frontier" as a historical symbol of America's epic past. As evidenced by the popularity of the frontier and the frontiersman even in mainstream culture before 1893, Turner's ideas were not necessarily new, but his thesis highlighted the loss of this space as a potential problem for the United States. Linked inextricably with American national identity (in Turner's opinion), the frontier's new role as a space of the past created a void in the present moment, and potentially in the future: "He would be a rash prophet who should assert that the expansive character of American life has now entirely ceased ... the American energy will continually demand a wider field for its exercise. But never again will such gifts of free land offer themselves" (38). This uncertain future is the premise into which his thesis is built, and the question of where to find the next frontier is one that preoccupied

\footnotetext{
${ }^{27}$ Additionally, Turner describes the encounters of westward-moving settlers with the land in the same manner that he describes encounters with buffalo and Natives - the buffalo and Indians falling into the "natural" side of the binary construct, with European civilization constituting its opposite. Obviously, it would not have been uncommon to categorize indigenous peoples in this way during Turner's time, as it allowed the government to justify taking over the land and disposing of its non-white inhabitants.
} 
politicians for the next thirty years - and perhaps, some may reasonably argue, even into today.

A number of thinkers have interrogated and dismantled Turner's work since it became popular, as the ideas generated from his frontier thesis bring with them some serious limitations, both academic and cultural. His simplification of the character of a nation as identifiable in a singular symbolic figure is useful as a framework for understanding national rhetorical constructions, but the thesis is actually built on the assertion that the citizenry has fundamentally changed. His essentialism is problematic, glossing over the genocide of indigenous peoples in a triumphalist offhand mention of the "war with the Indians," and simplifying the expansion of the nation as if it were simply a natural masculine outgrowth, obviously ignoring the institutionalized role of unfree Americans, namely the black slave labor that built many of the markers of the civilization to which he refers.

The notion of this conquest reproduces specious extensions of Darwin's work into scientific racist justifications for white hegemony, which treats the expansion of Anglo civilization as the natural progress of human history. Especially knowing as we do that federal policies of the late nineteenth century advocated things like hunting bison for sport (to the point of extinction), guaranteeing the starvation of many indigenous tribal inhabitants (and/or ensuring their surrender to federal treaties and the poverty of reservation life) (Edwards 37-8), Turner's thesis was not just inaccurate, but dangerous in its implications. While the shortcomings of his thesis, as we look back from our current position, obviously reflect the historical and social milieu in which he lived and worked - and the perspectives Turner promotes were not uncommon amongst white 
middle class Americans - with each new academic or scientific treatment of nationality, gender, class, or race that justified (explicitly or implicitly) a belief that human value could be measured and labeled according to arbitrary differences, a powerful destructive force within humanity gained credibility and power.

In spite of these problems with Turner's thesis, scholars of American history since then have readily acknowledged the role of the frontier thesis in shaping the future of historical study, and perhaps the future of the nation itself. "Turner's thesis was rife with inaccuracies, of course," writes Heather Cox Richardson, in West from Appomattox, her exploration of American western expansion during the Reconstruction Era, "[b]ut it identified a central national fear," she continues: "Was America really different from Europe, a world in which God had provided enough resources so that every hardworking man could rise? Or would the loss of the frontier leave the nation to degenerate into class warfare, a New World copy of Old World struggles" (282-3)? David Wrobel's interest in this mythology is similar to my own. Whether or not the frontier actually closed, his work examines how the perception of the frontier's closure affected the behaviors of people and created anxiety around the idea of a closed frontier, and how those perceptions shaped history in the modern era.

The lasting import of the frontier myth and its power in its own time, Wrobel states, is "symptomatic of a wider frontier anxiety that emerged in embryonic form in the 1870s and became more pronounced in the succeeding decades" (3). Turner was not an expansionist and had not necessarily advocated expansion, but his thesis and its emphasis on progress as it was defined by continual movement and expansion made the prospect easy to sell. With the closing of the frontier, after all, the American identity and the future 
of the democracy were at stake (57). In fact, Woodrow Wilson, who was a friend of Turner's, relied heavily on the Turner thesis to justify expansionist imperatives, citing the basis of his reasoning on the premises in the essay. It should be noted, however, that Turner never categorically stated that Americans should expand, but proposed that historians consider that the closing of the frontier would affect the future of America in a major way (58).

Turner's historical methodology alone was an innovation that promoted new approaches for interpreting history. Rather than highlighting leaders and major historical events as the fundamental hinges on which society turns, Turner's method promoted the notion that humans are shaped by the environment, and that American character has developed into a distinctive type because of the unique qualities of the landscape of the U.S. This was a watershed moment for scholars of history, as well as countless other disciplines that have integrated cultural-spatial concerns as key elements of interpretation. ${ }^{28}$ Turner scholar William Cronon points out the "bottom up" approach that Turner championed before it was a popular method of studying history has been one of the key shifts in historical methodology. He also notes Turner's impressive storytelling ability, and describes it as prophetic in its capacity to distinguish developmental stages for the nation, effectively reorganizing our entire concept of American history. Turner's thesis "canonizes" those stages as measures of human progress, according to Cronon (165). Events and developments that had been disconnected prior to the Turner essay now

\footnotetext{
${ }^{28}$ The renowned geographer Jared Diamond's 1997 Pulitzer Prize winning exploration of the role of human adaptation to geography, for instance: Guns, Germs, and Steel, approaches the development of societies and the history of European conquest through a lens that factors geography as the prime shaper of humans. His work, coming roughly a century after Turner's thesis, has, expectedly, applied methods of human geography to the study of global conquest in a more conscientious fashion than scholars in Turner's era tended to do.
} 
seemed to be connected in a "grand sequence of civilized ascent" (166-7). This concept was exciting because it made sense out of a new Republic founded on what was commonly referred to as an "experiment" in democracy.

Turner's present-minded historicizing was not a hallmark of traditional historical approaches. By interpreting the past from the position of his present time and space, his work helped introduce a distinct historical perspective that lent his ideas a new academic and social urgency and ensured that they maintained a lasting relevance-a perspective that still operates today across social sciences and humanities. The concern with which Turner premises his work — that of the closing of the frontier — was an innovative platform that helped the thesis resound through multiple generations. Historian of the American west, John Mack Faragher, refers to Turner as "America's first truly modern historian," concerned as he was with how the present continues to be shaped by the past (Faragher 4). The insistence with which he emphasized the closing of the frontier as the sign that "the first period of American history" was now closed (Turner 38) not only linked the present-day nation directly to its past—offering an account that mined the histories of the Natives, the buffalo, and the European fur traders as part of the amalgamation that constituted the "American"— but it also seemed to predict the future (though Turner's essay does not suggest or claim to know the future for the nation). His theory seemed prescient, and as such, the "destiny" of America seemed to be written into the subtext of his treatment. Turner's work simultaneously gave America a deeper past, and license to pursue a trajectory of expansion into the future, because in his estimation, it was in the American's nature to do this. He effectively distanced American imperialism 
from old world imperialism simply by virtue of the claim that this brand of imperialism was natural frontier character that the very wilderness itself had bred into Americans.

\section{Heterotopic History: Telling and Selling American Progress}

Of particular concern for this chapter is the construction of the frontier as a fixed space. Turner discusses the human conquest of the frontier as if it were a fight between two natural forces, suggesting that the land could be conquered by humans. He also argues that these humans were shaped by the land, creating an anthropocentric equivalency between land and human (a variant on the "man vs. nature" trope), with the "fittest" winning out. The Foucauldian concept of heterotopia, unlike a perspective of history that sees a series of "glaciations" across the terrain of spacetime, offers a way to perceive patterns or connections in human existence without the confines of an exclusively spatial or temporal privileging. Heterotopias, as Foucault defines them, are spaces that relate to all other spaces, but which maintain certain unique properties that allow them to exist as Other spaces, or counter-sites, often situated amidst easily identified and controlled spaces, and yet simultaneously operating outside those spaces; or perhaps existing not within any one space, but across/within multiple spaces (Foucault, "Of Other Spaces" 3-4). Heterotopias are the Other spaces that, in some ways, can realize a spectrum of potentialities that the utopia cannot. ${ }^{29}$ Foucault defines the utopia as a necessarily non-existent place, but his description of the function of the utopia invites us to consider the heterotopia as an alternate site of theoretical space that actually does exist,

\footnotetext{
${ }^{29}$ This inquiry is not assuming a positive or negative value for the heterotopic space. I offer a reading of heterotopias like the frontier in order to illuminate their potential as texts, and to better understand the societies in which they function. As mentioned above, these spaces often serve multiple roles-sometimes hegemonic, sometimes marginal, sometimes both. I use Foucault's "heterotopology" here to help learn about the way moral, cultural, legal, and social authority is constructed through such symbols as the frontier.
} 
as what he calls "an effectively enacted utopia" (3). Heterotopias are the spaces where "all the other real sites that can be found within the culture are simultaneously represented, contested, and, inverted" (3), re-ordering the traditional ordering of spacetime and inviting a new focus on space as movement, where sites are no longer points on a map, nor are they movement between points, but where they are treated as constellations of inter-related moving points (2). Identifying and interrogating these spaces reveals the values of a given society, where things that happen, as Foucault says "behind closed doors" disclose societal fears and tensions in the act of separating them and making them Other spaces (8-9).

In an overview of the changing approaches to our understanding of space, which he offers as a prelude to his explanation of the heterotopic approach, Foucault talks of history viewed (in a Turnerian way), as "glaciations" of human movement through space. This, Foucault asserts, was the dominating historical perspective until very recently: a perspective that maintained a sanctified approach to spatial understanding. This approach, he says, limits our ability to conceive more fully of human history and its positions in the constellation of spacetime (1-2). Turner subordinates time to space in his historical analysis, but he still analyzes space as what he calls merely a "significant" aspect of history, and one that serves only to continue the tradition of the grand narrative of human history. His conception of spatial history is based upon the treatment of time as a desanctified variable, while space remains homogenous and sanctified. For Turner, history is a series of events frozen in space, contained moments along a linear path: "As successive terminal moraines result from successive glaciations, so each frontier leaves its traces behind it, and when it becomes a settled area the region still partakes of the 
frontier characteristics (Turner 4)." In this approach to space, once the frontier line has moved forward, the historian can now assess its impact, as if its tracks reflect the story of what happened in this space, almost as if the historian is performing a scientific experiment and studying the results against a hypothesis, or performing the work of a detective collecting evidence, deduction.

The Turnerian approach treats space as fossilized, observable formations, when, as Foucault explains, spaces are fluid constellations of movement (2) and can change their meaning and their impact, even from their own transient existences. Unlike the purely utopic space, which serves a single conceptual function and remains homogenous, fixed, and closed, heterotopias are varied and rich, sometimes marginal and sometimes hegemonic, and often inhabiting multiple spatial categories (4). Turner's approach to space, however, was an important landmark in modern reinterpretations of American history, and his treatment of space as a homogenous and sanctified landscape, like a stage for the dramas of humanity, explains the Progressive reverence for this kind of spatial understanding. To a Progressive Era politician like Teddy Roosevelt, Turner's thesis would seem all but prophecy for American global dominance. It also helps to explain how Roosevelt's obsession with the west resulted in (or was driven by) the zealous belief and promotion of the idea that the United States was fulfilling its exceptionalist destiny by entering into the Spanish American War in 1898 - an event that helped solidify his own status as a modern-day conqueror of the wilderness.

\section{Might is Right: Teddy Roosevelt as American Archetype}

The Progressive Era was defined in large part by its politicians, but also by a host of related social movements that converged at the turn of the century, and which 
continued through the 1920s (Kloppenberg 362). With an emphasis on moral virtue, civic devotion, masculine virility, and nationalistic pride, Progressive reforms instilled a sense of order into a society that had felt disorganized and fragile since before the Civil War, and more so afterward, during the scandal-ridden Reconstruction Period (or Gilded Age, as it is also known). In No Place of Grace: Antimodernism and the Transformation of American Culture, 1880-1922, historian T.J. Jackson Lears uses Max Weber's theories of the association between Protestantism and capitalism to examine the effects of the bourgeois counterculture - which he labels "antimodern"- on the history of the U.S. This small, but powerful cultural movement arose in response to the modern influences of post-Civil War industrialization and all the attendant destabilizing forces on the middle classes of the era (things like secularization, large-scale immigration, scientific and psychological fads, and first-wave feminism, among others). For the white, middle-class male, it was a time of acute insecurity, when institutions and belief systems so long entrenched in the cultural fabric of the U.S. became sites of criticism. As the nation underwent the profound changes that accompanied an overhaul of the economic and social order, so too, were its inhabitants forced to process these cultural shifts. This is the time when, according to Lears, the bourgeois American began a desperate search for authority as a reaction against increasing moral ambiguity in the culture. ${ }^{30}$

Long before his Presidency, Teddy Roosevelt was notoriously committed to projects of reform, both personal and social. Born and raised in a sophisticated,

\footnotetext{
${ }^{30}$ While Robert Wiebe's The Search for Order [1967] remains a seminal text for examining Gilded Age concerns and questions of authority, Lears' monograph examines sub cultural movements and follows smaller-scale shifts in art, religion, and science to draw our attention to the rise in popularity of certain figures that embodied aspects of the antimodernist sentiment. Wiebe's work serves as a useful study of the effects of the Civil War, while Lears' focus on collective psychology illuminates the underlying machinations of the society that resulted from the Reconstruction Era climate and provides a contextual foundation for a critique of the frontier myth.
} 
intellectual New York household, the son of wealthy blue bloods (his father a northerner and Union sympathizer, his mother a southerner and Confederate supporter), Roosevelt was conscientiously shaped by his parents to be a hard-working, civically-minded paragon of virtue, intellect, and benevolence - a moral compass and paternalistic embodiment of the noblesse oblige (Dalton 18-20). Roosevelt's father, Theodore Sr. (or, Thee), like others of his rank, insisted upon extended European tours for his children, believing that such a journey provided the foundation for a proper, well-rounded citizen. To be hearty and strong in mind, as well as spirit, Theodore Sr. adhered to the "muscular Christianity" ethos, a value system which gave rise to the Young Men's Christian Association (Y.M.C.A.), and which promoted the antidote to sin and temptation as a soldierly strength that resisted self-indulgence and channeled sense pleasures into a righteous path of athletic competition and body strengthening (Dalton 17-8). He insisted on regular physical exercise for all of his children, as well as frequent excursions in the outdoors, to build immunity to the "moral typhoid" taking over the nation (Dalton 50). The elder Roosevelt considered this vigorous physical lifestyle as a crucial component for proper Christian development.

Born weak and sickly, many of Teddy Roosevelt's biographers note his steadfast determination to "make himself" hearty and strong in the image of his father, in spite of his fragile health. As he grew into adolescence and adulthood, the younger Roosevelt's resolute vow manifested in an obsession with physical exercise and weightlifting (Dalton 50). ${ }^{31}$ These characteristics of the "strenous life" advocated by the Roosevelts, and so

\footnotetext{
${ }^{31}$ This "self-making" reference comes from an oft-cited incident in Roosevelt's childhood, where the small, sickly boy reportedly vowed to his father, "I will make my body" before embarking on his famous lifelong intense physical exercise regimen. I have encountered this reference repeatedly in studies of Roosevelt, in
} 
commonly attached to the popular figure of Teddy Roosevelt, resonated with many late nineteenth century Americans. In Teddy, the nation found an admirable role model for grit and self-will, a populist patriarch whose authority came from his notoriety as a tenacious and hard-edged reformer as much as it did from his Ivy League education (Dalton 129-30). Roosevelt's frontier ideology joined with his emphasis on moral purity and promoted a compelling notion of the U.S. as a "self-made" and righteous space. Following years of scandal and disappointment with the failures of the Reconstruction Era, Roosevelt's promise to clean up and strengthen the nation was a timely message, and his Progressive brand of leadership provided a new and trustworthy political authority for Americans.

The curious mix of frontier mythology which celebrated the common man and rejected European social hierarchy on one hand, yet still glorified expansion, material wealth, and conquest as worthy goals on the other, was reconciled via social reform movements, which grew to all new heights in the Progressive Era. ${ }^{32}$ In The Republican Roosevelt, John Morton Blum defines imperialism as "The combination of white supremacy, national glory, and moral obligation," in government leaders (31). The contradictions which might otherwise make the Progressives' political platforms seem disingenuous found coherence in the "cleaning up" rhetoric of nineteenth century colonialism, borrowed from domestic reforms in the sanitation and public health

multiple biographies, which suggests that this "self-making" is seen as an essential facet of the Roosevelt persona.

${ }^{32}$ Richard Slotkin's Gunfighter Nation offers a thoughtful analysis of the Rooseveltian slant on Turner, which he attributes to Roosevelt's privileged, Eurocentric upbringing. For Turner, the yeoman farmer of Jeffersonian Democracy was synthesized with the Jacksonian hunting man, but Roosevelt attached his own patrician European sensibilities to Turner's construct, rendering it a mere justification for colonialism in the vein of his English ancestors. Political Historian James T. Kloppenberg (referenced above) also notes Roosevelt's move away from the theoretical principles of American Progressive philosophy as he reinterpreted the concept ever more loosely to fit his imperialist zeal. 
movements. Faragher describes the mythological constructs of expansion and purity that Roosevelt and other Progressive Era leaders tapped into:

Among the mythologies that sustain American identity is that the United States is an 'innocent nation'... This manifests itself in various ways, from seeing Americans as a 'chosen' people to anticipating that the United States will lead the world into a millennial age of peace and freedom. Alongside these beliefs operates the assumption that Americans, and America itself, are righteous, virtuous, and pure. $(83)^{33}$

Throughout the late nineteenth and early twentieth centuries, when social reformers like Jane Addams, Upton Sinclair, and Jacob Riis were bent on cleansing the nation of its unsavory elements - corruption, criminality, and poverty, as well as dirt and pollutionthe connection between dirt and disease began to extend to concerns of moral impurity. Juilann Sivulka discusses the psychological and sociological consequences of inadequate hygiene and sanitation in the Progressive Era, in her book Stronger Than Dirt, noting that a deep "shame culture" that so closely links sin to dirt is distinctly Anglo-European, and that the Puritan influence in the U.S. allowed it to spread especially easily in discourse in the new Republic (44). "[T]hrough a pervasive field of laws, taboos, and censorship," writes Sivulka, "sanitarians relying on institutions instructed a nation bent on progress that filth bred chaos and barbarism, while cleanliness ensured order and advancement" (107).

\footnotetext{
${ }^{33}$ For further reading on the construction of the U.S. as an innocent nation, Faraghar suggests Richard Hughes' work on Christianity and American mythological constructs, while Marita Sturken's Tourists of History continues this exploration into the current era of terrorist fears and the national myth of innocence as it is maintained through kitsch memorial memorabilia.
} 
This rhetorical use of physical dirt as an extension of moral impurity was enmeshed with the justifications for colonialism in Europe and the United States in the nineteenth century. Famously, the Pears' Soap advertisements at the turn of the century were enthusiastic promoters of colonizing the "dark corners of the earth," to cleanse them of their associations with barbarism, starting with a good scrubbing. The February 1899 issue of McClure's Magazine is a perfect example — an unabashed celebration of all things colonial. It was in this issue of the magazine where Kipling's "White Man's Burden" debuted, along with a lengthy romantic treatment of the trail, by Hamlin Garland, which reads like a poetic version of the Turner thesis, as Garland muses, "The trail is the sign of things vanishing; the evidence of nature untouched and unsubdued. It stands for a world of free men and wild animals" (Garland 304). Garland's essay deepens the constructed divide between the farmer and the hunter that was situated in the divide between the eastern and western regions of the U.S., calling hunters men "of another world." "Men are getting so thin-skinned," he asserts, "so dependent on rubber boots and tin roofs, that the hunter riding forth alone on a journey whose circuit is a thousand miles seems like a man of another world - as he is" (303). The same issue of McClure's includes a lengthy article titled "Dewey at Manila," which extols the heroism of Admiral George Dewey in the conquest of the Philippine Islands.

A similarly laudatory article on Dewey was published by none other than thenGovernor Theodore Roosevelt in an October issue of McClure's in the same year. When the Pears' Soap advertisement featuring Dewey, titled "White Man's Burden" was published in that same October 1899 volume, it synthesized a number of sentiments expressed in the February issue of the magazine (fig. 1). 


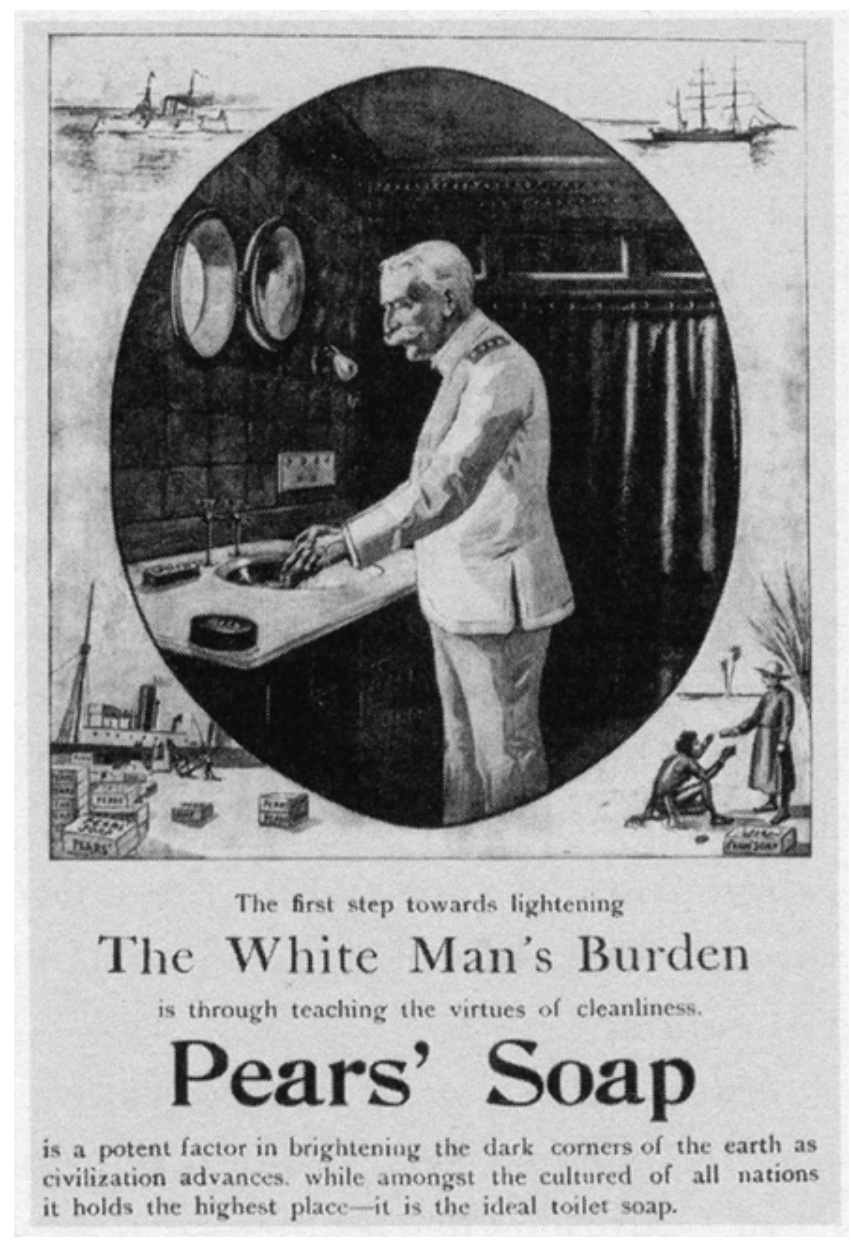

fig. 1. Pears' Soap Advertisement, Admiral Dewey. 1899. Library of Congress (https://lccn.loc.gov/2002715038)

The image of Admiral Dewey standing before a washbasin with a bar of Pears' Soap in hand dominates the ad space. In the margins of the ad, illustrations evoking images of the arrival of the U.S. fleets on the shores of the Philippines are conflated with the arrival of ships carrying crates of Pears' Soap. In the bottom right corner, a dark-skinned native, wearing only a loincloth, squats before a well-dressed white man who proffers a bar of Pears' Soap to the eagerly outstretched hands of the aborigine. The text at the bottom of the ad asserts that "The first step toward lightening the White Man's Burden is through teaching the values of cleanliness," and promotes its soap as "a potent factor in brightening the dark corners of the earth as civilization advances." The advertisement 
reveals a combination of Progressive urges that supports colonial expansion even as it commoditizes the conquest and simultaneously treats the mission as the altruistic imperative of a self-sacrificing nation. The goods produced by western civilization are inseparable from the western expansionist justification in this advertisement, which uses the honored position of capitalism to give credence to the notion of the SpanishAmerican War as a just war.

The Spanish American War marked the first of many global imperial conquests by the United States (often under the guise of paternalistic intervention), and Teddy Roosevelt's starring role in the endeavor has as much to do with the power of his storytelling as anything. A prolific writer, Roosevelt penned, among many books, a memoir of his time in the war. His account of the war and his adventures as a Rough Rider are, not surprisingly, glorifications of the war and of his fellow soldiers. In his account, Roosevelt casts himself in the role of the model American, and he offers up the space of the Spanish American war as the model scene of conquest.

In his autobiography of his time in the war as a volunteer cavalry leader with the $1{ }^{\text {st }}$ Division, also known as the Rough Riders, ${ }^{34}$ Roosevelt devotes sprawling sections of prose to outlining the "types" of men who make up his division. As a leader of the group, he explains that he sought his first volunteers from the southwestern territories, believing them to be best equipped to fight in Cuba by virtue of their experiences in the ungoverned landscape of the southwest. The accolades he showers on the men who fought for him in the war generally tie their fitness as fighers to their moral character, with the measure of a man largely based on either his good breeding or a lifetime spent in the "untamed"

\footnotetext{
${ }^{34}$ Roosevelt claims that the nickname was given to the unit by the public: [F]or some reason or other the public promptly christened us the 'Rough Riders"' (15).
} 
regions of the country. Of one soldier, Roosevelt writes admiringly that he "had lived for twenty years in the Territory, and had become a thorough Westerner" Another in his division was the "ideal of what an American regular army officer should be [...] fifth in descent from father to son who had served in the army of the United States, and in body and mind alike he was fitted to play his part to perfection [...] he looked what he was, the archetype of the fighting man" (Roosevelt 24). Most importantly, what all these men shared were "the traits of hardihood and a thirst for adventure. They were to a man born adventurers, in the old sense of the word" (25). Roosevelt, again unsurprisingly, compares himself to the men in his division, his confidence bolstered by their shared values: namely, affinity for the wilderness and enthusiasm for warfare.

The wilderness and violence are intertwined throughout his narrative, and Roosevelt frequently employs theatrical metaphors to express their synthesis, as when he offers this description of the first morning of fighting: "The lofty and beautiful mountains hemmed in the Santiago plain, making it an amphitheatre for the battle" (97). Narrating his charge up San Juan Hill, he leading the charge on his horse, Little Texas, while his Rough Riders follow on foot, Roosevelt again characterizes the scene of battle as one of pure joy (103). As they perform the tasks of digging trenches, running into battle, or otherwise engaging in tedious work during breaks from fighting, Roosevelt gushes over his men, who share an almost pathological glee in simply being at war, smiling, cheering, and "gallantly" reveling in their great fortune as they eagerly rush to follow his command.

This sanitary presentation of the violence of war, along with Roosevelt's lighthearted descriptions of combat and his effervescent refrains of admiration for fallen 
soldiers, constructs the space of the battle site as an ideal, almost picturesque scene of civilized and benevolent violence. The realities of war are disguised by the dramatic episodes of valor and nobility, and the conquest of the region is fashioned as an act of protection and good global citizenship. This narrative of Roosevelt's helps to reinforce an idea that took hold in the Progressive Era that these Other spaces exist to serve as a backdrop for scenes of competition and conquest to play out. The constructed frontier battle space of Cuba, as a heterotopia of compensation, is an unseen (but very real) site

presented as an ideal space of potential that serves to counter the "moral typhoid" against which Progressive reformers were waging their war. It is a space that, because of its siting on the frontier path of progress, is presented by Roosevelt as "perfect, as meticulous, as well arranged as ours is messy, ill constructed, and jumbled," (Foucault 8). Roosevelt advances the conquest of Cuba as a natural extension of American character, invoking the frontier of Turner and highlighting the exceptional American character of the troops and of the endeavor. If Roosevelt is the archetypical frontiersman, then the war against Spain and the acquisition of its territories is not about power or wealth, but about growing the American values of democracy and freedom, opening what Turner might have labeled a second chapter, a new frontier in American history.

\section{Filling the Field: The Early Art of American Empire-Building}

Though it was accelerated at the turn of the nineteenth century, and though the United States entered the international stage as an extension of the European quest for global dominance, the methods of conquest that we see employed in the Progressive Era had roots in early occupations of the Americas. In some ways, we can draw parallels between Roosevelt and the European explorers whose adventures and conquests on 
behalf of crowded imperial nations began the project of mapping, defining, and thus manufacturing space as territory to be claimed.

Early colonialist map-making provides a contextualizing tool for recognizing the legacy and reformulations of such propaganda as it has evolved through later generations in the new world. The creativity and artistic ingenuity of mapmakers was integral to the project of making unknown, unexplored, or even non-existent spaces comprehensible to Europeans in order to promote further expansion and colonize. European explorers sought territory that could be used for large-scale production—land they considered "empty space," but which, in their estimation, was nonetheless full of potential. These expeditions needed to create a realistic representation of potentially viable sites of development for colonialist expansion, but the element of appeal was just as important. In the case of land that was already inhabited by indigenous populations, artists fashioned this as empty space on their maps by disregarding or naturalizing as wild animals the civilizations that already filled it. Conversely, as historian Timothy Sweet explains, mapmakers injected realistic renderings of unrealistic situations — such as the superabundance of various fish species in one illustrated scene from the Virginia expedition, for instance — in order to "fill the field," with imaginary but plausible resources where there were none. Less important for the imperial duty of artists was the accurate representation of these lands so much as the attractive and believable renditions of them. Such products of early expeditions "rendered the space of representation, like the land itself, as a field to be filled" (Sweet 23), and effectively provided a representation of reality that served to justify further conquest. 
As the frontier of the new world was being "opened" by explorers in the sixteenth century, the written narratives of these conquests were constructed with the same approach to spatial representation as we later see in the Spanish American War, and as we continue to see in images of American warfare today. Baudrillard's theory of hyperreality defines the development of modern power as a process where we end up with territories constructed by the maps that came before them. His exploration of the Borges fable of imperial simulation and its inability to express the hyperreality of simulations of simulations is also an explanation of the frontier as a representation of reality that only exists through empty signs that even an event like the American Dust Bowl cannot make real, where "[o]nly the allegory of the Empire, perhaps, remains" (Simulacra 1-2). Acclimated to signs of power as stand-ins for actual power, the demand for signs, as Baudrillard explains, becomes the hyperreal substitute for even the simulation of power and authority ( 23 his emphasis). Roosevelt attempted to provide the nation with an empowered characterization of itself via American conquest—notably prefigured in his "self-making" and the hyperreal image he crafted for himself as a roughriding modern day cowboy and tough moral reformer-but the public embrace of that image had as much to do with his effective use of the fears engendered by the loss of the frontier as it did with his charismatic persona.

Richard Hofstadter refers to the Spanish American War as a crisis that is "inseparable from a larger constellation that might be called 'the psychic crisis of the 1890's," which was due, in large part, to economic depression of 1893 as well as the political upheaveal that Progressives instituted, and of course, the "closing" of the frontier. "[T]o the mind of the 1890's," he says, "it seemed that the resource that had 
engaged the energies of the people for three centuries had been used up. The frightening possibility suggested itself that a serious juncture in the nation's history had come" (1489). Baudrillard reminds us of the operational logic of crisis as an instrument of control: "[P]ower plays at the real, plays at crisis, plays at remanufacturing artificial, social, economic, and political stakes" (23). The psychic crisis evoked by the fear of losing a sign of power like the frontier (among other things) justified the emergence of new representations of the frontier - signs and symbols that cropped up not only in nostalgic pop cultural phenomena and imagery, but in foreign policy, as well.

Roosevelt's presentation of the Spanish American War and the myriad propaganda that sold global expansion followed in the footsteps of early new world expeditions. His imagery of the war "fills the field," in a sense, with the kind of compelling scenes we later see represented in films and television shows about the "wild west." By the turn of the twentieth century, we seem to have crossed over, "into a space whose curvature is no longer that of the real, nor that of truth" (Baudrillard, Simulacra 2). Likewise, as we assess the rhetorical forces that sold the myth of the Plains as a viable "empty" space for inserting the Jeffersonian yeoman farmer, we recognize the familiar pattern of snake-oil space making in pursuit of political viability.

\section{Dust Bowl: The Great American Desert of the Real}

The Turner thesis could well be argued as one of the defining concepts of American identity in the twentieth century, but a case could be made that another, less popular understanding of the frontier as a space not conquered or conquerable, perhaps reflected the era more plausibly. In October of 1893 — the same year as Turner's thesis was first introduced — well-known explorer and geologist John Wesley Powell was 
invited to speak at the International Irrigation Congress in Los Angeles. Historian Wallace Stegner describes the Congress as “Powell's natural ally,” because, like Powell, (who believed the west could not support a large population increase), those who rigorously studied irrigation generally took a more conservative view in determining how irrigable the western regions really were (Stegner 342). When he arrived at the conference, however, Stegner writes that Powell was dismayed to hear fellow scientists discussing settlement in the Plains "as if the whole billion acres of the remaining public domain could be irrigated, as if the whole West could be reclaimed" (343).

An unexpected blow to his faith in his fellow researchers, Powell realized that the nation's feverish determination to settle the Plains once again was not likely to be dampened, no matter how well-established the reasons against it: "Major Powell put aside his planned speech and told them that they were mad. The highest percentage of reclaimable land that he had ever ventured, in the first flush of his Irrigation Survey optimism, had been twenty per cent. His more confirmed guess now was [...] about twelve per cent" Powell was scorned by his colleagues, and was actually booed throughout his speech (Stegner 343; Tarlock 1313-4; Wrobel 55). Less than one generation after Powell's warning, millions of families in the Great Plains region were forced to evacuate the region because it had confirmed, once again, that it could not sustain life on a large scale (Worster 49).

After a glut of emigration in the Reconstruction Era, harsh weather during the 1880s had led to the first major exodus from the Plains regions. At the turn of the twentieth century, however, geographic surveys and government-funded projects abounded, seeking to redeem the region. Hoping to transform the Great American Desert 
(as it was then called, [Raban 22]) into a viable source of farmland, these pushes by the government brought a second, and much larger influx of newcomers who hoped to settle and make a living as agrarian producers. The largest population increase came between 1910-1920, according to Dust Bowl scholar Brad Lookingbill (19). Because of coincidental rainfall in the early years of the land rush and profitable years in the 1920s, people moving to the area thought the promise of land renewal had been realized, but they were met with the devastating reality of the region soon enough (19).

As it was originally envisioned in the image of Jeffersonian democracy, the United States was expected to be a nation of small yeoman farmers, who would populate the unsettled parts of the nation and breed a citizenry of landowners who shared equally in the abundance of America. The Homestead Acts began first with Land Ordinances in 1784, 1785, and 1787, which settled the northern Midwest and Appalachian regions (Hughes 6-7). The 1862 Homestead Act eventually opened land further west. While the midwestern areas of the U.S. continued to represent the ideal of small, thriving homesteads and farms that resembled those back east, this model of ownership and farming was untenable in the Plains regions. The region could produce good crops in a year with unusually high amounts of rainfall, but this was a rare occurrence (Stegner 7). In short order, those who had settled in the Plains realized the area could not be farmed, and this disappointing reality led to a mass migration out of the area in the $1880 \mathrm{~s}$.

Following the Dawes Act of 1887, which divided Indian Reservations in the Plains into individual tracts and sold off major portions as small plots of farmland, The 1889 Indian Appropriations Act opened Oklahoma territory, adding this land to the 1862 Homestead Act (Rister 396-8). This Act followed a decade of disputes that had begun in 
the late 1870 s between "Boomers," settlers who believed the tribal lands were legally bound by the Homestead Act to be part of the public domain, and the Native tribes who had been ceded the territory by the Federal government in the 1851 version of the Indian Appropriation Act (396-8). After years of continuously defending their land from whites who staked claims on it, the land was finally sold off to the U.S. in 1889. This transfer of land was only possible because of the earlier passage of the 1871 and 1885 versions of the same Act, which, respectively, removed tribal claims to land and made each Native an individual and a ward of the Federal government (Edwards 203-7) and subsequently, declared Indian land free for sale by individual tribe members who claimed territory that was still unoccupied (206). With the tribal reservation dissolved and opened to homesteaders, the Oklahoma territory underwent a "metoric" population boom from the resulting land rushes of the 1890s (Wrobel 54).

Railroads were a major factor in the settlement of the west during this time, as well. Railroad companies laid tracks across the country, and even as they took advantage of new towns cropping up after the Homestead Act to market their lines to the highest bidding small-town government, the railroads also began to create entirely new towns to meet their needs. Jonathan Raban's Bad Land examines the settlement of the upper Great Plains in the Progressive Era. In the late nineteenth and early twentieth centuries, new railroad companies produced towns to justify and fund their rail lines—-sometimes, according to Raban, indiscriminately penciling in new railway stops on a map with no particular reasoning or forethought, or arbitrarily making and then just as quickly deleting a town on the line, based on a whim or a personal change of preference: 
The half-built new towns, in which the typical business was a shed with a two-storey trompe l'oeil façade tacked onto its front end, were architectural fictions, more appearance than reality; and their creators, the railroad magnates, speculatively doodling a society into existence, were like novelists. (20)

The Presidents of railroad companies had the power to make towns by running the line through it, or to allow a town to die by navigating around it or simply speeding through it without a stop (21). In their pursuit of bottom line returns, however, these men helped foster an untenable kind of progress. Many of the towns they fearlessly brought into existence were born only to eke out a mere survivalist existence and then die, ultimately serving as signifiers of the failure in their status as ghost towns - many of them erased even from symbolic cartographic representation.

Raban discusses the massive advertising campaigns that railroad companies used to persuade easterners and newly arriving immigrants to settle out west. Companies like the Milwaukee Road Railroad and Northern Pacific mailed colorful information booklets all over the U.S. and Europe, promising free land and a bright future as a profitable farmer in lush, untouched regions of the American heartland. The bold claims of these advertising campaigns made impossible guarantees, one of the most compelling of which was an informational supplement that potential settlers could send for, and which would explain why the area formerly known as a desert was now perfectly suited for high-yield farming. The Campbell Method was retained, for instance, by the Milwaukee Road pamphlet. The pamphlet, as Raban explains, suggested that "serious homeseekers" should exercise good sense by reading through Campbell's book, referring to Campbell as "“the 
noted farming expert and inventor of the Campbell System of scientific farming for semiarid lands."' (qtd in Raban 30-31). These farming theories, backed by little research, if any, were promoted as cure-alls for the vast expanse of land that had been written off as unusable for major crop production (Tarlock 1313).

State and Federal politics also played a major role in promoting the illusion of a sustainable homestead in the Plains. It was clear that the Great Plains were not like the midwestern regions of the U.S., but the desire to get homesteaders into the region and occupied by constituents again after the first disastrous settlement was too great for politicians to ignore. The pseudoscience of the Campbell method, along with the grossly incorrect "rain follows the plow" adage, were promoted by politicians as often as they were pushed by corporations looking for consumers. The parcels of land that were distributed in the Homestead Act were far too small to allow a crop farmer to profit, but politicians were opposed to increasing size of the land allotments. "Frontier politicians" pushed population growth in their townships in order to secure political power and pass the required population threshold to become states in the Union, which would allot two Senators and federal recognition (Libecap and Hansen 4-5).

\section{Tilling the Field: The Unsettling of God's Country}

In 1878 - several years before he was booed off stage by his colleagues for his unpopular assessments—-John Wesley Powell gave a report to Congress, recommending that the Homestead Act be amended to better suit the needs of farmers in the region, who were destined to fail at the small farming of the kind seen in the east. Powell recommended land allotments 16 times larger than the 160 acres in the legislation, stating that 2,560 acres per farmer would be a more realistic way to settle the area, which was 
more fit to support livestock, rather than crops. His report was ignored (Stegner 7-8). Later, even the Enlarged Homestead Act of 1909, which doubled the acreage of plots to 320 , was still grossly inadequate to create functional farms for settlers (Raban 112). An added problem in the Homestead Acts was the requirement that in order to receive permanent deeds, homesteaders had to continually cultivate the land with crops for a minimum of five years, which exacerbated soil erosion and helped create conditions for the Dust Bowl (Raban 33).

The land was far too small for grazing, which was all Powell believed it could provide, yet even when the federal government offered subsidies for farm losses, the subsidies still required farmers to plant crops. The number of representatives in the House was at stake, as were property values in rural communities, and related investments in schools and other infrastructure. This is why local and state politicians lobbied D.C. for subsidies to maintain small farms through the Farm Security Administration, the Works Progress Administration, the Farm Credit Administration, and the Federal Emergency Recovery Administration (Libecap and Hansen 25). Keeping as many people on the land as possible was the only way to keep the infrastructure intact. The frontier would stay closed this time, as far as the lawmakers were concerned.

Freedom, democracy, and the frontier mythology were pursued by both the farmers and the lawmakers, and these abstract concepts became channeled into Progressive policies that sought to materialize this theme by settling the Plains, but these theoretical principles became subjugated to an empty, homogenous capitalist space that served only as a groundless reference. In the Plains, Jeffersonian democracy and frontier American exceptionalism were real only in the advertisements of free land. These ads 
sought settlers who were willing to exchange their faith in the American Dream for the facsimile of it. These spaces of abstraction substituted as the frontier, showing up only on paper in deeds and claims, and in the series of legislative acts that closed and reopened, contracted and expanded the boundaries of public domain and land requirements for settlers, and, of course, for Native tribes. Indigenous tribes were continually forced off their land due to treaties and legislation that changed their reality and rights with each new "opening" of the frontier or discovery of new homesteading markets.

This re-opening and closing of western spaces via the extension of theoretical concepts that had no place on the ground show how the fifth principle of heterotopia works. The image of the frontier that was promoted so heavily during the Progressive Era is a conception of spaces that will "always presuppose a system of opening and closing that both isolates them and makes them penetrable" (Foucault 7). These sites, Foucault says, are not necessarily open spaces, free for all, but spaces where one is not given the choice, and is forced to enter or exit - as in the Indian Removal Acts - or a space where "the individual has to submit to rites and purifications. To get in one must have a certain permission and make certain gestures" (7). Invited in, new claimants were required to cultivate the farms of the kind cultivated by those in the eastern rural areas, regardless of the capacity of the land in the west. The opening of these spaces was contingent upon meeting the demands of the laws which governed this "free" space, and many who staked claims could not meet the requirements, yet those who did were to blame for the soil erosion that led to the decade of dust storms which this illusion of Jeffersonian democracy had perpetuated. 
Banking on the theory that simply tilling the soil and continuing to plant crops with faith that the rains would come next, Great Plains settlers were caught in the speculative world created by the promise of free (or very nearly free) land and the dream of owning a piece of America. Year after year, farmers attempted to utilize crops and techniques they had used back east, or which had been advocated by persuasive profiteers, but these approaches were doomed to failure. Theories like the "rain follows the plow" maxim fortified farmers for a number of years on the vague hope that enough plowing would bring the promised rainfall in the next growing season. By the mid 1930s, however, settlers were giving up on their dreams and struggling just to survive.

\section{Apocalypse Now: The Verisimilitude of Wrath}

In public discourse and popular literature of the 1930s, a strong anti-expansionist sentiment took hold of the nation and many Americans embraced policies of the New Deal Administration, eager for better governance and control of the economic system within the borders of the United States, rather than a continuation of policies that only spread the empire further, to the detriment of those citizens living on the soil of the U.S. While people like John Steinbeck, Woody Guthrie, Dorothea Lange, and John Wesley Powell were producing works that revealed the deep rifts between the triumphalist rhetoric of the early twentieth century and the reality of its consequences for the inheritors of those policies, those who were living in the Dust Bowl were interpreting the over-expansion of their nation in other ways.

Popular images of cowboys and nostalgic resurgences of such pioneers heroes as Davey Crockett and Daniel Boone helped distance the American version of colonialism from the European version, at least on the surface, while the liberal use of the frontier 
myth and Turnerian understandings of American character promoted exceptionalism and manifest destiny. The platforms of Progressive presidents and leaders allowed this storyline to gain traction, bolstered by images of such men as McKinley and Roosevelt as moral crusaders, whose strident masculinity was proof of their God-given fitness for international leadership, engendering a national desire to be at once morally pure and unabashedly hegemonic. This frontier bravado, however, was shattered by the stock market crash of 1929 and the subsequent Depression, which lasted through the better part of the 1930s.

The simultaneous decade of dust storms over the western Plains states was a direct contradiction of the Progressive Era's assertion that expansion was a natural phenomenon. The frontier that had been conquered, or "closed" as Turner had phrased it, had not been conquered at all, and in fact, the conquest and settlement of the Plains had been a disastrous mistake, made twice in the span of one lifetime. The settlers who were encouraged to stake their futures on the arid region were not equipped for a losing battle against nature. If the American pioneers were simply following the path carved out by the buffalo, the Indian, and the nomadic fur-trader, then their decision to to take a region with 20 inches of rainfall a year, which had never been considered viable farmland, and turn it into farmland was considerably off the beaten path (Edwards 45).

The over-growth of the Progressive Era immediately preceded what could be described as a movement backward for the frontier, the economy, and for American exceptionalism. By mid decade, it was becoming difficult for farmers to avoid adopting a fatalistic view of the future, especially after the massive storm that hit the Plains on what became known as Black Sunday. The event, which occurred on April 14, 1935, has been 
well documented by those who experienced it, and nearly everyone who witnessed the event described being blindsided by the ferocity and swiftness of the storm:

[T]his was a beautiful Sunday afternoon until this came up. Well, during the meantime, we had a church meeting for the elders at the church, and they became so frightened, one of my friends told me, she said, 'Those that could $[\ldots]$ could see to get to the altar, they prayed, and those sat in the pews.' And said, 'There was one or two that would just lie down in the aisle because they thought this was the end of the world.' (Stallings 16) Making sense of the dust storms, by 1935, was no longer a matter of trying to predict the weather and planting crops with a prayer for rain, nor was it a matter of searching for another farming method to coax the land to give what it didn't have the means to give. The nightmarish storm of Black Sunday seemed to confirm growing fears that some other, less obvious manner of sin had brought forth the severe consequences that now blighted this region. Survivors noted that the day had started out unusually warm and sunny, which explains why so many of the stories of that day begin with outdoor recreational activities, or in church. One survivor describes the difficulty with which witnesses comprehended the surreal scene before them:

They thought, 'Well, now, the Bible tells us that the Lord will come back in a cloud.' But they thought a cloud from the sky, naturally, and said, 'Maybe they meant this was the cloud.' And they thought this was a queer way for Him to appear-in a cloud of dust. (Stallings 16)

The simple acceptance of apocalyptic prophecy expressed in so many narratives of the disaster reveals the underlying beliefs of many in this part of the nation. The majority of 
Plains state residents who identified with religious groups held beliefs that can be categorized as evangelical or fundamentalist Christian beliefs. The doctrine of fundamentalists and evangelicals is hinged on the second coming of Jesus, and those who ascribe to this strain of Christianity (which was, and still is, extremely popular), "often believe strongly that the world will come to an end [...] On that day, or one near it in time, they believe that the earth will be transformed in accordance with God's wishes" (Lookingbill 225-7).

In the areas hit by the Dust Bowl during the 1930s, many of the more traditional Protestant churches struggled to maintain their membership numbers, yet the number of evangelical and fundamentalist churches and members actually increased (Lookingbill 275). Lookingbill notes that even those residents of the region who didn't regularly attend church or necessarily adhere strictly to any particular set of beliefs, nonetheless interpreted the Bible literally, in the evangelical tradition (276). Of special importance in this set of beliefs is the emphasis on the end times, presumably prophesied in the Book of Revelation. This last book of the Bible, just as all other Biblical texts, is read literally by evangelical and fundamentalist Christians as the description of the final days of Earth, when a number of plagues will descend from God and the righteous will be called to Heaven for eternity.

The term "Dust Bowl" first arrived in print just after Black Sunday. Neil Shumsky examines the etymology of the name and its relationship to religion, arguing that the apocalyptic overtones of spiritual traditions in the rural areas of the nation directly affected the popular understandings of the dust storms, which exacerbated early twentieth century fears of being morally corrupted by the filth of modern lifestyles. The name 
given to the region after the Black Sunday storm was almost immediately adopted in public discourse. The New York Times introduced the term, and this publication alone used the phrase hundreds of times between 1935 and 1937, while the Los Angeles Times used the phrase over two hundred times in the same time span (Shumsky 218). Attributing its origin to the word, "bowls" in Revelation, in reference to the plagues which are visited upon humans by God as part of the second coming of Jesus, ${ }^{35}$ Shumsky explains that the disaster of dust storms in the region seems to have been named after the plagues of Revelation (229-30). That the name was so rapidly integrated into the popular discourse regarding the dust storms of the 1930s, suggests that those who sought some explanation for these horrific phenomena had found a plausible answer in the very labeling of it all.

It was widely recognized early in the 1930s that over-cultivation had caused the conditions that led to the storms of the 1930s, but the ferocity and frequency of the storms, and the impossibility of knowing if and when the onslaught would ever end, triggered a deeper need for meaning in the midst of the suffering in the area. The storms felt like punishment. "Although much of the blowing dirt and drought lacked the extreme drama of Black Sunday," Lookingbill writes, "the religious symbolism provided an available and convenient method to explain the sense of foreboding and calamity ushered in by the decade" (283). It is not difficult to find symbolism in a storm that descends, seemingly out of nowhere, in the midst of a bright Sunday afternoon. In its associations with God's day of rest after creating the Earth and everything in it, along with the

\footnotetext{
${ }^{35}$ Shumsky is referring to new translations of the King James Bible, which was called the Revised Version in England and which was published in 1885. The King James Version is still more widely used in the U.S., but the revised version of the English edition from 1885, which is called The American Standard Version, was published in 1901 and is still used in the U.S. (228-9).
} 
expectation amongst Christians that work on this day should take a backseat to worship, praise, and spiritual communion, the imagery of a sunny sky suddenly shifting to a hellish, roiling black shroud of dust that engulfs the entire landscape - people and animals included — would be disturbingly rife with Biblical connotations.

At times, the dust left behind by the storms covered homes up to the roofline, halted people in their tracks if they were unlucky enough to be outside, choked and suffocated countless animals and, occasionally, humans, to death (Hurt 51). These moments of awe and terror in the experience of surviving such epic ecological events that overtook the land hundreds of times throughout the 1930s increasingly began to filter into the psyche of those who survived the storms, over and over again, throughout the years. Even as the threat of homelessness and starvation became ever more real with each passing day, "dust pneumonia," as it was called, brought on chronic lung diseases, which often led to a slow decline and early death in otherwise healthy people (Worster 18-31).

A common refrain among those who experienced the Dust Bowl firsthand was the almost total inability to see anything in front of them, described by numerous survivors as being so blinding as to make it impossible so much as "to see your hand in front of your face" (Stallings 8, 17, 20, 52, 67). This recurring description emphasizes the panic of losing oneself in the dust, of coming to the troubling realization that the dust has become so thick as to render it impossible to confirm whether anything or anyone remains, perhaps even one's own body. One particularly evocative description of a survivor describes the uncanny sensation of this invisibility to herself as feeling like "[y]ou were completely blotted out." (Stallings 13-4). 
The language of punishment, sin, guilt, and wrath, which pervaded the discourse of the Dust Bowl, reflects (and perpetuates) a society living under a yoke of shame. Buying in to the myth of the future as it was presented by frontier capitalism and the Rooseveltian "making" of oneself in the pursuit of ownership was a risk that was contingent upon faith in a world where the labor of the farmer can be reduced to a monetary exchange value based on market conditions, and where land is a commodity. In this schema, the objectification of the farmer and the land equivocates them, but in doing so, renders them empty of inherent value. Walter Benjamin describes capitalism as a "cult that engenders blame," rather than redemption. Upon experiencing guilt, this structure clings more tightly to the mechanism of its own closed system of cause and effect and translates guilt into blame, implicating even God in its explanatory framework, "in order to finally interest him in repentance" (Benjamin 259). Because this religion eschews repentant discourse and perpetuates itself by operating on a world of blame, whereby the doctrine of capitalism must assuage guilt by referring back to itself as a victim of God and assuming this position as universal truth, the capitalist cult creates a system that values nothing but its own endless perpetuation, without redemption, "a world of despair still only hoped for" (259-60). The "worries" of this cult are situated in hopelessness, but Benjamin notes that it is not a material hopelessness, but a spiritual hopelessness brought on by "poverty, vagabondism-begging-monasticism. A condition that is so hopeless it is culpable [...] 'Worries' originating in the fear of hopelessness that is community-based, not individual-material" (261).

The storms of the Dust Bowl (and, of course, the economic Depression) broke down the illusion of the blamelessness of capitalism for many Americans, calling into 
question the belief that there was an inherent purity in progress. Especially for those who lived in the areas affected by the disaster, the concern with blame and the role of God in this disaster raised questions about who was culpable and how redemption would be found. Residents began to believe that they were paying for an investment in a sinful proposition, yet, Benjamin notes that capitalism attached itself "parasitically" to Christianity in the west, in Calvinist and more traditional Protestant systems alike (260). Understandings of each storm as isolated, or of each season as one bad season in a series of discrete growing years, some of which might or might not be as bad as others, were now challenged by the labeling of these storms, and of this time and space, as a "dust bowl," a plague of dust poured down by an angry God. This new association of the region with the Biblical end times challenged the blameless ethos of capitalism and brought on the kind of hopelessness that Benjamin sites as a particular worry of capitalism, as the term "Dust Bowl" consolidated the separate storms into a larger consequence of worshiping the false idol of material gain. In fact, with each passing year that farmers held on to the hope that planting more crops would end this cycle of destruction, the devastation grew worse. Even into the 1940s, when Americans could not know whether the storms would continue or not, preachers were invoking the Dust Bowl to reference the consequences of sin and provide an example of what happens to sinners.

Overtilling the land and expanding crops in spite of drought, year after year, the misguided reactions of farmers in the first half of the 1930s offered the perfect illustration for the crimes of greed committed against nature in general. In a sermon which was published in the New York Times in July of 1939, the well-known Reverend Joseph P. Sizoo likened the United States to the example of Adam from the Book of Genesis, 
discussing Adam's complicity in the fall of paradise: "It does not matter what happened to Adam - he failed to obey the law. This is true in everything, whether it is the law of God, the law of gravity, the law of fire. This is true of the individual and it is equally true of nations" (Sizoo 15). The nation, as well as the individual, was being judged, and lawlessness of man or country would have consequences just the same. The sermon uses the Dust Bowl as an example of the dire consequences of disobeying the laws of God: "Until we have a new awareness of God, no matter who our President, no matter what our government, the dust bowl will not bloom again" (15). Making the catastrophic events of the Dust Bowl into a metaphor for the wages of sin was a useful tool for preachers, and it was employed widely, even in the popular narrative of the Dust Bowl as the result of human sins against nature. The cult of capitalism was widely challenged by this rhetoric, yet New Deal policies were able to channel the troubling hopelessness of the dire circumstances into a rhetoric that located redemption in the economic policies of FDR's administration, circumventing any question of sin or punishment.

In March 1936, the New York Times published an article from H.H. Bennett, Chief of the Soil Conservation Service of the US Department of Agriculture. Bennett's article was written like a letter to the American public and presented the administration's findings on the causes of the drought and dust storms, assigning blame to problematic human farming techniques:

In the past we have shrugged at these elements and blamed nature. Wind and rain, we said, are natural phenomena over which man has no control. We have fought floods at their point of effect—with levees, reservoirs and 
revetments - instead of at their point of cause; and we have fought duststorms after the havoc has begun, although precaution is the cure. "We know," adds Bennett, "that they are manmade and that both are consequences, paradoxically, of the misuse of our land [...] The conquest of America has been largely a conquest of nature" (Bennett). Bennett's emphasis on rectifying Americans' wrongful blaming of nature, and his set up of the past-present dichotomy as a way to frame the causal connections between the human use of land and the land's reaction extends the empowering construct of the man vs. nature binary. The work of reconciling this disaster with the exceptionalist narratives of American capitalist democracy relied on the federal government's swift attention to addressing its citizens' unmet needs while also narrating an inspiring storyline about the untapped potential of the American people, all of which relied on a blame game that required figures of authority, whether spiritual or political, to chastise the farmers for their destructive methods and to provide the authority of a redemptive path. The failure evident in the Dust Bowl required a state narrative of the event as an example of the just frontier law of sin and punishment through nature's wrath, with the farmers in the role of wayward sinners and the government in the role of the redeemers.

\section{Frontier Faith and Filth: How to Pray the Dirt Away}

Nineteenth and early twentieth century wisdom advocated frequently airing out domestic spaces, because stagnant air was still considered by many to be a potentially dangerous source of illness (in spite of the fact that germ theory had recently disproved the "bad air" theory of disease that had been the standard theory for centuries). In the home, especially, it was important to keep fresh air flowing in, as it was believed that the 
stale air that inhabitants had been exhaling into the home throughout the day and as they slept at night was full of toxins that could carry disease into the body as it was breathed back in. Women were advised to open windows and doors daily, to bring in the clean air from outdoors and let out their "bad air" (Brown 234-5). This theory of illness perpetuated the opposition between the urban and the rural, with the wholesome, clean rural air providing an antidote to the polluted urban areas, which were choked with stagnant, unwholesome air (235).

Shumsky points out the troubling connections that those experiencing the dust storms would have likely made between the dirt that seemed to coat everything in their lives and the fears of disease and moral corruption symbolized by it (224). The pure, open spaces of the farms were idealized as sites of healing and regeneration. This blight of dirt that now plagued the sacred frontier spaces, which should have been, by their nature, impervious to the kind of filth and corruption that afflicted the overdeveloped cities back east, sullied the relationship of Americans with their frontier, and with it, also tarnished the faith in Progressive expansionist projects that were justified by the frontier mythology. The frontier was now refusing to stay closed, retreating backward from its own line of progress with massive force and enveloping the homesteaders of the Plains with its will to return to an unsettled region, fit only for grazing or passing through.

As Turner attempted to redefine American character and the project of forming and re-forming the identity of the nation continued, the illusion of a pure, healthy, and forward-moving society was revealed as such in the Hellish realities of the Dust Bowl. The fundamentalist, evangelical Christianity of the Plains (also that of a large portion of the U.S.) was quite different from the "muscular Christianity" of educated, old money 
Progressives like Roosevelt. Those men recalibrated the moral compass of the U.S., creating a religious frontier sect within the cult of capitalism, while the settlers who were actually filling the space, figuring political progress in their claims to land and in their crop yields, as well as in their constitutive bodies, revealed how the exchange of their time (and their lives) in return for this frontier space of mythical potential actually exchanged, and they paid an exorbitant price for the mistakes of a Progressive leadership that dealt only in imagined futures.

Halting the cycle of settlement and exodus that had already been enacted on the Plains in the mid-nineteenth century on a smaller scale, the storms of the Dust Bowl stopped motion forward or backward in the frontier. While a number of farmers were able to relocate, vast numbers were stuck in the region with nowhere to go, or were forced to stop on their migration and set up camps in the middle of nowhere, outside traditional domestic spaces, in temporary shelters that served as transient communities and temporary homesteads. This frontier expansion and contraction parallels the boombust cycle of capitalism. By design, the economic cycles of capitalism invite the endless revision of historical myth-making, but for the span of the 1930s, when the U.S. was operating on a wholly new plot of spacetime contraction due to the scarcity of the Depression and the ecological damage perpetuated in the west, the speed of American history was slowed, if not halted. America had already mapped out its frontier history, but in heterotopic moments like the Dust Bowl, where the manufactured territory of progress is revealed as an illusion — a sign with no referent — the shame that the failure begets will insist on playing out the same plot over and over, hoping to find grace enough 
in spiritual redemption to close this chapter of the frontier and move forward into a sustainable future.

\section{The Dirty Thirties Redeemed: Interstellar Rewrites the Future}

The 2014 film, Interstellar begins with footage from Ken Burn's 2012

documentary, Dust Bowl. In the opening scene, clips of Burns' elderly subjects are shown in succession as they detail their firsthand experiences growing up in the Dust Bowl. One man describes how, as a child, the family dinner table was set with plates facing down so that when the food was served, the family wouldn't have to re-clean dirt from their plates. Those who have seen the documentary (and, likely, many who haven't seen it) can ascertain quite quickly that this footage refers to the American Dust Bowl of the 1930s. Because these scenes are introduced without reference to any specific time or place, however, it's left ambiguous as to how the audience should interpret these interviews. They essentially exist as free-floating narratives, ghostly apparitions who haunt the film.

Following the Burns opening sequence, the scene changes, and an early twentieth century farmhouse comes into focus. The home looks like a quintessential American Dust Bowl Era home and is coated with a fine layer of dirt, inside and out. Dinner plates placed upside down on a kitchen table evoke the interview from moments before, and a hand enters the frame, turning a plate up to reveal a circle of clean space on the dusty surface. The old-fashioned imagery is complicated, however, when the shot pans to a laptop computer, which is also picked up by someone's hand to reveal a clean rectangle of space beneath it. The juxtaposition of the future and the past as compressed into a relationship where one cannot be separated from the other is the motif that runs throughout the film. For all intents and purposes, the present moment is virtually non- 
existent, merely a jumping-off point for a backward or forward movement in time.

The setting of the film's present moment is one of mere survival. All of the characters in the film are the survivors or descendants of the survivors of a nearapocalyptic food shortage. The ongoing apocalypse of humanity is drawn out, however, and in spite of the reprieve that seems to have lasted about a generation — which is where this film begins, in a world where those who remain are able to eke out an existence on the remnants of Earth's natural resources—it becomes clear quite early that the Earth's resources are almost completely exhausted. Crops routinely fail and as farmers set fire to withered stalks, coming to grips with the reality that another year's harvest has died, we learn that entire species of food are gone forever with these failures: "Okra, this year," has gone extinct, states one character. "Now there's just corn."

Set roughly two generations into the future, the 2014 viewer of Interstellar is represented in the elderly Donald, who is the father-in-law of widower, Cooper (or, Coop, as he is often called). Donald recalls life before food shortages depleted both the land and the population. He describes the freewheeling over-indulgence of humanity that led to the disaster, born of an arrogant faith in technology. The hubris of his generation (ie: our current generation), whose confidence that the future was destined to get better and better and that science and technology could solve basic problems of resource mismanagement, is the regret forever on the lips of Donald. It would seem that all of the potential for the future has been spent in bad investments, and, as Baudrillard might phrase it, that the "orgy" of the utopic symbol that was America is now over (America 105). 
Earth is undergoing a slow, painful demise, and its death is one that Coop finds all the more maddening because his purpose as a mere survivor now renders his former life as a NASA pilot meaningless. The role of education, too, has dramatically changed. Public schools stand nearly deserted, with just a handful of students and a small cadre of pragmatist teachers whose role is purely to instruct the next generation on the essentials of surviving life on Earth. The curriculum no longer offers astronomy, and in fact refutes humanity's past progress in space travel. The moon landing, according to the new history books, never happened. In an exchange between Cooper and a teacher, Ms. Hanley, who struggles with Coop's 12 year old daughter, Murph (named for Murphy's Law, her defiant attitude toward the limits of the curriculum creates frequent discord in the classroom), Ms. Hanley says that the official approach to the history of space travel by Americans is that the moon landing was

a brilliant piece of propaganda, that the Soviets bankrupted themselves pouring resources into rockets and other useless machines [...] [a]nd if we don't want to repeat of the excess and wastefulness of the twentieth century then we need to teach our kids about this planet, not tales of leaving it.

We learn, additionally, that most students will pursue vocations as farmers. No matter their intellectual promise, the majority of children bear the burden of feeding the planet with almost no means to do so. This generation will not be expected to send anyone to space, and as the film continues, we realize that it is likely the last generation of humanity altogether; The Earth has become a giant, never-ending Dust Bowl. 
The defeatist strain that this scene represents is symbolic of the larger narrative of defeat that pervades the broken society of the film, though that pessimism is countered by Coop, whose tenacity and faith in the future is reminiscent of the frontier rhetoric of the Progressive Era. If Donald and his generation have been so humbled by their mistakes that they are hesitant to do more than simply hold on to the barest existence and await extinction, then Coop — just one generation younger than Donald, is determined to fight the fatalism of today with continued investment in a future that no one else seems to believe will ever arrive. As the two of them sit in the stands of an unimpressive baseball game (an unsatisfying re-creation of an idyllic past with the subpar athletes who survived the famine), Coop notes that his coming of age was marked by violence and starvation of people the world over, who were killing each other in the streets for food. He believes that the world he now lives in has essentially already died, because it has given up on the future and on the dreams of their ancestors. Coop laments to Donald, "We used to look up at the sky and wonder at our place in the stars, now we just look down and worry about our place in the dirt."

Interstellar presents the future on an Earth that is apocalyptic and postapocalyptic at once, dying and already dead. There is no future for this planet: Earth has stopped producing, and aside from meager crops that dwindle every year, the dirt is just about all that remains, and dust storms of the kind we saw in the Burns film are a regular occurrence across the globe, with no end in sight. In one evocative scene, an adult Murph passes a caravan of gaunt, dirty evacuees who bear a marked resemblance to the imagery of Steinbeck and Lange. ${ }^{36}$ These refugees stare blankly ahead, seeming to see nothing,

\footnotetext{
${ }^{36}$ Where these refugees are headed is not clear, considering the premise of the film is that the Dust Bowl has become the condition of the entire planet.
} 
crowded into the cabs and beds of farm trucks in pathetic attempts to escape the omnipresent plague of dust. Nolan tells a story of apocalypse by reimagining a past event in U.S. history, and his choice to evoke the era of the Dust Bowl to convey this concept relies upon the audience's collective experience of the event, even if only through a second or third-hand memory: “"The dust storms were very important to Chris, this apocalyptic parallel back to the old Depression Dust Bowl,' Assistant Director Nilo Otero explains. 'It's something that exists in people's minds, if not as a memory then certainly as an image"" (qtd in Vaz 66).

The staging and plot of the film rely on a representation of a real past and an imagined past whose verisimilitude negotiates the boundaries of collective memory and mines the depths of American faith in the frontier. Costume Designer Mary Zophres designed the clothing for the film with the Dust Bowl in mind, and when she describes her approach to the fashions of near-future humans, Zophres states that her direction to herself was to focus on the conception of the Dust Bowl as a moment transmitted into the present: “'Don't even try to predict the future. It should feel timeless and wholeheartedly American"” (qtd in Vaz 40). This film takes place in the future, but it isn't really about the future; rather, it's about America's reckoning with its failures. To this end, Interstellar goes to great lengths to make the science fiction aspects of time travel (as the apparatus of redemption) seem realistic, in spite of the fact that Nolan softened his representation of the Dust Bowl. In a Time magazine interview, Nolan says his decision to insert the Burns footage into his film was inspired by his emotional reaction to the documentary: "'I was watching it for research and was so moved by it,' $[\ldots]$ 'We could not in the film make it as bad as it really was or people wouldn't believe it"' (qtd in 
Corliss np). A major focus of critics and writers on the film was its devotion to showing the science of interstellar travel as realistically as possible, and this aspect of the film was promoted heavily and discussed in nearly every interview, with Nolan often mentioning that he hired famed theoretical physicist Kip Thorne as an advisor. Frequently missing in discussions of the film, however, are Nolan's understanding of the Dust Bowl and why this event was so significant in his conception of the future. Nolan's plausible presentation of an implausible technological future of time travel and his promotion of the film's realistic science fictive renderings of this future are effected by our return to a moment in a not so distant past, but where the past we try to remember is being re-written and inserted into our future as a new history.

If we think of the time of the Dust Bowl within the fictional framework of Interstellar as an example lifted from its moment on the map of history and placed in the service of the future, the disaster again shows itself as a heterotopic and heterochronic space of illusion, a non-time and a non-place, the closed world of blame brought on by the capitalist treatment of time as an empty space. The 1930s Dust Bowl is the unseen hand that is invisible because it is obscured by a barrier of dust, which surrounds everything, triggering a profound uncertainty about its own existence and marking a break in the forward march of frontier progress. The film moves us directly from past to future, and the present moment functions, once again, as the space of illusion, in myriad ways. Elderly Donald is the analogue to the viewers' generation, and the film begins after the apocalyptic events that occurred in his past (and our future).

Coop, as the representative of the film's present generation, is an exceptional individual who saves humanity through time travel, and in order to do that he denies the 
historical constructions of the past, rejecting the apocalyptic framework and re-writing the past as he experienced it, an act that will also renegotiate the story of the future, forcing it from a space of non-existence to existence (and particularly, a re-creation of the existence he has known his whole life-a replica of Earth on another planet). After saving humanity in a quest that took several decades in space, Coop returns to discover that his species has vacated Earth and now temporarily resides in a space station, awaiting the discovery of a habitable home planet. Interstellar conceives of the Dust Bowl as the example of the end, deploying the present moment of the film as that moment of Armageddon, standing for and marking the site of apocalypse.

The survivors of the Dust Bowl—both the Dust Bowl of American history and the Dust Bowl of Interstellar - are themselves representatives of the apocalypse, as well. Serving this function inside the site of the apocalypse renders them similarly invisible and removes them from existence within the order of apocalyptic understanding, so that they are both apocalyptic beings and beings who exist outside the apocalypse. Coop loses the entirety of Murph's life because he travels to find a new planet, spending the span of her life working toward this goal and sacrificing his own present moment but not losing the future, instead moving past the present moment of his own lifetime (and his daughter's lifetime), to exist in the after-moment of apocalypse.

The method by which Coop is able to help save humanity is via two mechanisms of spacetime compression, both of which shrink the present moment into non-existence. The ship that Coop pilots is plotted to enter a galaxy far enough from Earth that it requires a wormhole to reach. The film explains wormholes in detail and then renders a trip through one to the far-off galaxy in question (which is never named). The wormhole 
offers a method by which linear spacetime can be folded in upon itself, Coop explains, effectively dropping the present moment from existence and positioning past and future as two edges of a paper are linked by folding it, making everything between the two edges immaterial. This wormhole was placed in the close vicinity of Earth by some benevolent beings from outer space, who are unknown and referred to simply as "they," but who seem to want Earthlings to find a way to survive by locating a new home planet. The wormhole fast-forwards the explorers to the site "they" have mapped for them in pursuit of a habitable planet to call home, which is where the film's plot actually begins.

In the climax of the film, Coop transcends spacetime again, this time escaping the confines of the present as well as the past. Upon realizing the ship will not have ample fuel to return home, Coop finds a solution by using the gravitational pull of a black hole to access the unknown spacetime potential of the singularity within. In doing this, Coop is able to make use of the fifth dimension, which means that not only can he travel through time, but also that he can travel on multiple planes in time, not just forward or backward. This enables him to contact both Murph and himself in the past and to send a message to them in binary code that will set them on the path to humanity's salvation. Coop reshapes the past via his manipulation of spacetime in the fifth dimension so that Murph can solve the problem of time travel. To do this, he communicates from the fifth dimension via gravity (by causing dust to fall in the pattern of the binary code she needs, as well as altering the magnetic field so that a wristwatch he left behind for her will signal the urgency of her moment and direct her to his message), making the space of the present moment the medium of communication between the future and the apocalyptic end, effectively rendering the apocalypse as the site of the salvation, separated from time. 
In both instances, Coop is bending spacetime, folding the past onto the future and using the present only as the site of the beginning of non-existence.

As he and his crew travel in search of a new home planet, those who still exist back on Earth are aging, experiencing time at a pace that far exceeds the movement of time in outer space. This identifies the third representation and annihilation of the present moment, though this representation is one that effects apocalypse precisely because it does not bend spacetime. While Coop and his crew are on their mission, the ship moves forward and the crew does age, but their distance from the gravitational pull of the earth means that they age at an exceptionally slow rate. The present moment of Coop's is slowed down to a pace that, in comparison to the rate of time experienced on earth, seems to all but stop. When he finally succeeds in his quest to redeem the past and the future, Coop returns, having missed an entire human lifetime on Earth. Murph is now an old woman and Coop is still the same as he was when he left, now young enough to be her son, and his long-awaited reunion with his daughter is concurrent with her final moments of life.

The film's end reveals that the beings communicating with the present moment characters are actually Earthlings from the future who placed the wormhole in close range to Earth so that their former Earthly selves could essentially locate a shortcut into other galaxies. With echoes of the early European explorers' obsession with finding a passage to India, the film's cast endlessly frets over time and movement through space, dogged by the unlikelihood of ever making it back home again. ${ }^{37}$ Interstellar's

\footnotetext{
${ }^{37}$ The taglines on promotional posters for the film are all thematically linked, echoing familiar frontier refrains throughout American history, from early colonialist exploration to mid-century space exploration, using "mankind" as a clear reference to the moon landing as the beginning of a new epoch in manifest destiny that constructs American manifest destiny as the antecedent of this new chapter in human history:
} 
juxtaposition of the Dust Bowl with the theme of interstellar colonization is a loose linkage of nonetheless interrelated ideas that may or may not form a cohesive story, but which come close enough together to make a compelling adventure epic and to lay claim to this narrative as particular to American identity. Nolan is re-writing our contemporary American historical moment as the response to Turner's thesis. The frontiers on Earth are closed, and it is our destiny, our responsibility, in fact, to colonize other planets The film is decidedly American, even though it's presumably telling the story of humanity as a whole. "Many in the Interstellar production team saw the film as a call for America to return to greatness," writes interviewer Mark Cotta Vaz (Vaz, 147). It is, after all a NASA ship and crew that saves the Earthlings, and baseball games are the pastime of choice both on Earth and in mobile space colonies at the film's end. Coop and his descendants were not the humans who destroyed Earth, but the inheritors of it, and the saviors of the future. The film employs this message throughout. The Earth of Coop and Murph is a cruel, limiting Earth to which they cannot relate and that they would be all too happy to leave behind. Life after the apocalypse in this construction is the limbo of afterlife for an innocent society born anew out of the destruction of the Earth. In his discussion of the afterlife, Agamben discusses the spacetime of the apocalyptic end for unbaptized children:

Like the freed convict in Kafka's Penal Colony, who has survived the destruction of the machine that was to have executed him, these beings

\footnotetext{
"Mankind was born on Earth. It was never meant to die here," "Go further," "The end of Earth will not be the end of us," and "Mankind's next step will be our greatest." Additionally, the film's official website includes a link for users to create a virtual patch for the crew uniforms, with a drop-down menu that allows an individual to choose his or her national flag, which will appear on the patch alongside the ship logo, rendering all nationalities as conjoined with American exploration, as the ship - built and operated solely by Americans-is the new America.
} 
have left the world of guilt and justice behind them: The light that rains down on them is that irreparable light of the dawn following the novissima dies of judgment. But the life that begins on earth after the last day is simply human life. (The Coming Community 6-7)

This is the moment of the messianic end. Those who want to return to Earth, or who the film represents as reluctant to give up on it are, notably, presented as the antagonists and the characters we blame for the damage wrought upon this species. Nolan is attempting to write the future as a pure and antiseptic rebirth, offering a promise of redemption in forgetting the past and estranging humanity from its flagellations of blame and guilt. In situating Coop and Murph directly on the point at which the spacetime of Earth is over, they are given the gift of grace. Their future will be a history-less future, ignorant of blame and guilt, a future that is "simply human life." A complication in this construction, however, arises in the remnants of the capitalist religion that still pervade this floating limbo of innocence.

The Ken Burns Dust Bowl documentary makes its way back into the final scenes of the film. After returning home and saying goodbye to his dying daughter, Coop is taken to a home that the space colonists built especially for him, and he realizes that his old 1930s-era farmhouse has been meticulously reconstructed in this floating colony. The scene-already surreal because of the anachronistic insertion of Coop's old fashioned home in the midst of the futuristic world of the colony—is all the more fantastic when he passes the front gate of his new/old home and we see that it is flanked by two futuristic television screens that stand as gate posts, and which are playing the same Dust Bowl documentary interviews as we saw in the film's first scenes. Coop wanders into his house 
and more such televisions are scattered throughout the rooms, looping the Burns' interview footage, although, oddly, Coop hardly seems to notice them.

The recurring loop of a mythologized pioneer is what opens the frontier space of the Dust Bowl to function as a heterotopic space of illusion, but the Dust Bowl also serves, due to its sheer magnitude across space and time, to serve as a break, or perhaps an interlude between cycles of future-oriented, forward-moving historical progress. Foucault calls this a heterochrony. Foucault's fourth principle of heterotopia is that it is "most often linked to slices in time" and that it "begins to function at full capacity when men arrive at a sort of absolute break with their traditional time" ("Of Other Spaces," 6) ${ }^{38}$ The old faces multiplied on the screens that surround Coop recount horrors of suffocation and starvation, consciously reconstructed and injected into the future, just like his Earthly farmhouse. The Turnerian frontiersman is the synthesis of past civilization (Europe) and a new society (America), at once old and new. This concept is figured in Coop, the ancestor to a new breed of civilization, one that is born on the frontier, although the presence of the worn-out past dots the landscape through the disembodied voices of a timeless space far away. This floating colony is the new frontier line, and the past is a representation removed from its reality many times over. This is not a space of limbo where innocents are blissfully ignorant of their lack of a relationship with God, but a heterotopic heterochronic space that exposes the chaos and disorder of both the past and the future in its very existence, acutely aware, in fact, of its purgatorial position within the cosmos, the nowhere/everywhere of interstellar homesteading.

\footnotetext{
${ }^{38}$ Foucault cites the cemetery as an example of this phenomenon, where the ephemeral and eternal meet, and he describes two modes of heterotopia in this principle — one of the accumulation of time: the museum, library, archive; and one of the passage of time, what he calls "time in the mode of the festival," a mode that privileges the transitory. He adds that these two modes are not necessarily incompatible with each other.
} 


\section{Apocalypse Now and Again}

Turner's story of American history says that we can go back in time through our own soil and witness the "progress" of civilization through our land. When Foucault discusses the nature of heterochronies, he describes heterochronies which seek to accumulate time and enclose it, an endless preservation of the past which only builds upon itself and which is the opposite of the other heterochronic function of "passing through," which we see in the ephemeral spatial constructs of the festival, for instance ("Of Other Spaces" 6-7). This tendency toward accumulation, born of modernity, is an urge toward "establishing a sort of general archive, the will to enclose in one place all times, all epochs, all forms, all tastes, the idea of constituting a place of all times that is itself outside of time and inaccessible to its ravages [...] organizing in this way a sort of perpetual and indefinite accumulation of time in an immobile place" (7). Coop's travel through a black hole and into a singularity is the definition of entering this space of accumulation, and when he contacts Murph from the fifth dimension, his perspective is from a space that has infinite options on the spacetime continuum to enter and alter. Likewise, the use of the remnants of the past to populate the historical character of the future is a circular movement that is based on a flawed myth of progress and frontier identity that will not be forgotten. The ownership of time and space that Interstellar envisions as the future American frontier requires the commodification of time and space, and is generated out of a desire to fix these concepts and to sanctify them as new backdrops for the next epoch of American history to play out.

The frontier rhetoric of conquest and progress was successfully used to populate the semi-arid regions of the Plains in the early twentieth century, but its implication as a 
floating signifier became evident when the region failed to recover year after year from a seemingly endless barrage of smothering dust storms that were brought about, in large part, from overpopulation and over cultivation. The Plains should not have been sold as a viable frontier prospect for settlers, and yet this speculative boom and bust happened twice in less than 50 years on the same piece of land. The economic and ecological disasters that spanned the decade of the 1930s raised (and continue to raise) important questions about the viability of a capitalist economy and the meaning and scope of federal responsibility in a time of national emergency. The apocalyptic interruption in the chronicle of American progress that is symbolized in major catastrophes like the Dust Bowl could also serve as a critical site for locating new moral authority new when old symbols are (even if only temporarily) emptied of their value. Roosevelt and Nolan's Turner-esque representations of space and Americanness sanctify space, but they also offer themselves up to heterotopic readings that invite us to reinterpret our understandings of the individual relationship to the larger storylines of national history, and think of the catastrophe as reflective of something more potent, and with more potential than an anomalous interruption in the progress of American history. 


\title{
CHAPTER THREE
}

\section{RUINS OF KATRINA: INVISIBILITY, CONTROL, AND THE AFTERLIFE OF NEW ORLEANS}

\begin{abstract}
"Petrarch asked if there was anything more to history than the praise of Rome. And we ask [...] 'Is there anything more to history than the call for revolution, and the fear of revolution?' And let me simply add this question: 'And what if Rome once more conquered the revolution?'" (Foucault, Society Must Be Defended 83-4)
\end{abstract}

Invoking the symbolism of the frontier to promote an imperialist mission, Teddy Roosevelt's progressivism tapped into a conception of power that relied upon an idealized construction of national character similar to that which had supplied Varina Davis's regal persona with authority over history and cultural remembrance. Roosevelt's effective use of Christian masculinity via the pioneer archetype to solidify his consciously "American" brand of leadership was built upon (and contributed to) popular cultural expectations for authoritative embodiment in figures of power that has nonetheless changed considerably in the generations since his Presidency. Perhaps, as briefly analyzed in Chapter One's discussion of the film, Jackie, and its portrayal of American figureheads as projected symbolic ascriptions of potential—rather than actual - achievement, somewhere in the twentieth century, the attempt to locate a comprehensible symbol of authority for representing democratic principles in the United States became an exercise in wishful thinking. 
In a democratic society built on capitalist ideals and embracing neoliberal philosophies that espouse individual agency while simultaneously removing it, totalitarian implementation is a necessary means to maintain the façade of democracy. In the linkage between totalitarianism and democracy, Agamben builds on Foucault's connection between subjectivization and totalization, as humans have become increasingly subject to, and accustomed to the "political techniques" of state power, where things like police, postal workers, and emergency workers become the responsibility of the state, and where the life of the individual has become subjective, and the "I," has taken on a new meaning_-inextricably linked with politics and state power (Homo Sacer 5).

The use of juridical ${ }^{39}$ exception is an effective tool to limit agency and transgressive opportunity for the population that is entwined in this machinery. Agamben describes the process of biopolitical control as ontological control, which allows for the rise of totalitarian governmentality under the law. Illustrating how the state uses "emergency" to justify the suspension of the law in order to shore up power and thwart resistance to its total control, Agamben discusses the "bare life" that can result from the biopolitical exception as a technique of power. Bare life is essentially the reduction of human life to its barest form, a state of mere survival. ${ }^{40}$ In his example of bare life, Agamben describes totalitarian techniques of power that brought about the concentration camps of Nazi Germany:

\footnotetext{
39 I refer to "juridical" as an authoritative mechanism that is based in the disciplinary realms of formal law and ancillary state institutions (eg: police, public schools, health and human services, etc.).

${ }^{40}$ Bare life is contrasted with a fully realized human life that entails potentiality, akin to the difference between "voice" as the fullness of expression on one hand and "language" as the form of expression, as Agamben describes it (Homo Sacer 11).
} 
$[T]$ together with the process by which the exception everywhere becomes the rule, the realm of bare life-which is originally situated at the margins of the political order — gradually begins to coincide with the political realm, and exclusion and inclusion, outside and inside, bios and zoe, right and face, enter into a zone of irreducible indistinction. At once excluding bare life from and capturing it within the political order, the state of exception actually constituted, in its very separateness, the hidden foundation on which the entire political system rested. (9) This particular illustration is useful for analyzing the effects of biopolitics in the United States - notably in its very visible operations in New Orleans during and after Hurricane Katrina - as it explicates the function of the state's biopolitical discourse on any number of levels where the exception is invoked as a political act and biological human life that has been embedded in the juridical order is reduced to its most basic ontological status as survival. In state's use of its authority to appropriate the emergency to suspend the law, it lays claim to total authority over human existence, as the state of exception necessarily becomes the rule.

Using the historical and cultural legacy of nineteenth century New Orleans Voodoo Queen Marie Laveau as an example of the way that the disembodied authority of corporate/state sovereignty has dislocated and displaced embodied symbols of power and potential, I offer in this chapter an analysis of the city of New Orleans as a performative space of transgression that has been essentially emptied of its power by the biopolitical structures that now control state operations in the U.S. This chapter builds upon an awareness that the shifting authorities and complicated statuses of individual and state 
sovereignty in New Orleans at various points during and since its colonization are crucial historical contexts for examining the significance of Hurricane Katrina for the United States as a whole. The response of the federal government to Katrina as standard operating procedure for a neoliberal nation state invites further investigation into this corporate governance as an outgrowth of the historical foundations of the U.S. as a bipartite slave state, a nation formed with the primacy of property functioning as a foundational impetus.

I explore the treatment of Laveau's legacy_in real life both before and after her death, and in fictional form through the popular television series American Horror Story - against the history of New Orleans as a contested space, because as a powerful free woman of color in antebellum New Orleans, Laveau's legacy offers a provocative and complex illustrative framework for considering the potential for transgressive empowerment in the United States, as the nation navigates into a future of post-national corporate hegemony. What Laveau's actual and fictional figure exemplifies in the story of New Orleans before and after Katrina is the threatening, vulnerable, and indecipherable status of transgressive embodied authority for a state power structure whose global hegemonic position nonetheless fails to assuage its fears of domestic rebellion from the margins. $^{41}$

\section{Colonial Confusion: Authority, Agency, and Color Lines in New Orleans}

\footnotetext{
${ }^{41}$ Carolyn Morrow Long's Voudou Queen is well supported, and consequently, her conjecture about Laveau's life is limited. She finds little evidence to support most of the well-known anecdotes about Laveau. I use Long's historical research, along with Marie Ward's more colorful biography, which contextualizes Laveau in her cultural milieu and includes a multitude of interviews from New Orleanians, who discuss the myth of the Voodoo Queen. A dissertation by Brooke Butler on "Voodoo tourism" contains useful discussions about Marie Laveau and her practices. In addition to primary newspaper stories of Laveau, which are limited, my analysis of Laveau is based on these various accounts.
} 
When the Louisiana Territory was purchased by the United States in 1803 , the society of the region bore little resemblance to the earlier settled areas of the eastern seaboard and those the U.S. acquired in its expansion westward, with racial categories and codes exemplifying the most obvious manifestations of this general dissimilarity from other European-settled slave states in the U.S. Slavery was nothing new to the city, of course. In Race, Sex, and Social Order in Early New Orleans, historian Jennifer Spear provides critical contexts for understanding how society in the New Orleans territory came to be seen as a kind of aberration within larger societal trends of antebellum America, with particular attention to the effect of colonial rule in the territory on the social castes of different groups in the region. Along with the early French colonists who had intermarried with Native Americans in the territory, eighteenth century French and Spanish settlers brought slaves from west and central Africa by the thousands (Spear 5054). While the French and Spanish colonial authorities each instituted their own black codes to maintain control over the African-descended populations of the territory, both free and un-free, the colonists held views on miscegenation that differed from the English ideal of the "pure" Anglo settlement. The place was entrenched deeply in its own complex social system, and Americans who came to reside in this newly acquired territory found it difficult to assimilate those who were already living there to the nation's social norms (Lewis 3-12).

New Orleans society had developed as its own unique global crucible several generations before the Louisiana Purchase and can be understood as such by tracing the networks of nationality in its inhabitants, notably illustrated in the multi-ethnicity of the vast majority of New Orleans' free people of color. These antebellum residents, in 
particular, were subject to distinct and continually shifting sets of expectations-socially and legally — and over time, they developed legal and extra-legal ways of navigating around the varying colonial authorities in the region (Spear 187-8). In spite of a restrictive French "code noir" and more moderate Spanish "código negro" of colonial New Orleans, free people of color (known as "gens de couleur libre") inhabited the city as citizens of a sort: generally tolerated, if not warmly accepted by white elites, and typically considered to be an integral part of the community. At various times in its colonial history, numerous legal rights were afforded this group, though it should be stated that they were not afforded the same status as full legal citizens (187). A number of free people of color, however, were property owners, and some were slave owners themselves (C. Long 17). ${ }^{42}$ Under Spanish rule, in fact, slaves had the right to purchase their own, and other slaves' manumission —even against the wishes of their owners (Spear 116-8). In their relative independence (an autonomy that can only be labeled as such when compared with the rest of the southern U.S.) the free people of color in New Orleans represented a cultural and ethnic ancestry with roots and branches that were impossible to clearly trace, embodying an inexplicable social and legal category that by its very ambiguity was imbued with a certain measure of power. ${ }^{43}$

Many gens de couleur had been born in the territory, often to other free people of color, and a large population of these men and women were mixed-race Creoles with

\footnotetext{
${ }^{42}$ Spanish rule was more liberal than French rule, though both countries created black codes in New Orleans in the interest of keeping blacks under control. Spain, however, outlawed the enslavement of Natives, and considered slavery to be only a temporary state. Slaves in New Orleans under Spanish rule had multiple avenues to freedom, and were allowed to work for money. From the date of Spanish acquisition of Louisiana until the 1805 census following the Louisiana Purchase, the percentage of free people of color increased from $7.1 \%$ to $33.5 \%$ (Roach $58-9$, C. Long 15 ).

${ }^{43}$ As Carolyn Long notes, regarding the "gens de couleur": "They were neither black nor white, but 'colored,' definitely not slaves but not quite full citizens. They constituted the middle tier in New Orleans' tripartite society" (21).
} 
ancestral links to wealthy white landowners (Spear 80-87, Berlin 109). These factors, among others, meant that notions of race in the Louisiana territory were far less definitive than in the English colonies. The typical bipartite modus operandi of slavery in the southern colonies was very different than in the practices of antebellum New Orleans, where skin color did not automatically signify social, economic, or legal status. While the institution of slavery and its reliance on binary racial divisions maintained a stronghold in the south and the color line in the rest of the United States was generally fixed, the population of free men and women of color in New Orleans demonstrated alternative understandings of power and status. Of particular note is the inclusion of free women of color in both society and business in the city. Of the combined wealth of free women of color in the Deep South, women living in New Orleans accounted for 92 percent of it, and they enjoyed an average of 20 percent more property holdings than other free women of color in the South (Spear 213).

At least in part, the creation of cultural communities and national affinities in the colony seems to have bridged some gaps created by racial and legal caste categorizations in New Orleans:

By the second half of the eighteenth century, people of African and of European ancestry probably knew each other far better than their parents or grandparents had $[\ldots]$ Whereas language, culture, and religion had separated the previous generation, those becoming adults in the 1750s and 1760s grew up with each other, speaking French and sharing Catholic religious practices. (Spear 142) 
Spear describes "de facto marriages" across racial lines that can be inferred from wills and other legal documents: "Such extralegal families coexisted alongside the more public face of interracial sex displayed at the quadroon balls, which, despite the best efforts of city politicians, flourished in the antebellum era." Even after the U.S. acquired the territory, whites and non-whites continued to openly display their relationships with each other (212). ${ }^{44}$ This defiance of American legal authority could be viewed less as hostility toward the new nation and may reflect, rather, how order in the city had been maintained unofficially, and how it was understood by citizens living under the jurisdiction of absentee monarchs.

The differences between New Orleans and the rest of the American South resulted not just from the French and Spanish governance of the territory, but from the city's large Haitian population, as well. New Orleans had more in common with France than with most of the other cities in the southern U.S., but the place also had significant commonalities with other French colonies, like Haiti. (Lewis 13-16, C. Long 25). The influx of Haitian immigrants following the successful Haitian slave rebellion had further established French/African influences that were all but impossible for newly settling Anglos to combat, much less understand, in their quest to "civilize" the city in the early days of American possession (Lewis 5-6, C. Long 28). While Saint-Domingue emigrants began to move to New Orleans in 1790s, the Haitian population of the city grew even more in the first decade of the nineteenth century. The early "trickle" of immigrants immediately after the revolution, writes Spear, "became a flood in 1809, when 3,102 gens de couleur arrived within a single year [...] This influx of free, French-speaking, Catholic

\footnotetext{
${ }^{44}$ The gradual adoption of the binary racial line eventually changed the society of New Orleans into one more recognizably typical of the American South, according to Spear, especially as the Civil War neared (212).
} 
refugees tripled the size of New Orleans' gens de couleur libre population to almost five thousand in 1810" (184). In the same year, Spear adds that the arrival of nearly the same number of slaves and nearly three thousand whites from Haiti changed the face of New Orleans dramatically (this massive emigration was due in large part to the expulsion by Spain of Haitian refugees who had settled in Cuba earlier in the decade) (184). The slave rebellion in Haiti altered the landscape of New Orleans significantly and in countless ways, not the least of which was simply via the injection of the Haitians' own multifaceted cultural and racial understandings into the city (Berlin 114-6).

The United States had diplomatic relations with Haiti even for some years after their revolution, but the fear of violent slave rebellion that haunted the typical white landowning elite in the Deep South was one crucial aspect of institutional racism that pervaded even New Orleans, as well (Berlin 115). Spanish and French governments had considered the possibility of violent slave insurrection a very real threat, and the linkages between New Orleans and Haiti only increased these fears. The Haitian Revolution was enacted not just by slaves, but by wealthy and high-status free people of color, as well (Berlin 115, C. Long 29). Thus, the Haitian Revolution, and the large Haitian presence in the southern U.S. had the effect of both empowering and endangering free people of color - even in cities far north of the Mason-Dixon line-whose sizeable population could be viewed as a serious threat to the race-based power structure (D. Davis 160).

\section{Voodoo Queen: Conjuring Power from the Margins}

If American settlers and tourists who came to New Orleans were troubled when

they realized the level of independence enjoyed by non-whites, their shock only increased when they encountered some of the cultural practices that were openly tolerated, and in 
some cases, encouraged in the city (Long 40-2). Quadroon Balls and plaçage, for instance, were widely accepted social customs in New Orleans (Cheung 8-10). ${ }^{45}$ Even in later years, the city's controversial experiment with Storyville — a short-lived, legalized red-light district established in the late nineteenth century - exemplified the town's pragmatic and decidedly anti-puritan approach to maintaining order and regulating the behavior of the citizenry. ${ }^{46}$ Voodoo practices, however, remained a source of suspicion for many people inside and outside the region throughout various colonial periods, and the religious implications of the practice were perhaps less troubling than the impact it had on the perceptions of power dynamics between whites and blacks where it was popular (C. Long 40, 102). ${ }^{47}$

The Voodoo Queen, Marie Laveau, is an exception to common historical expectations for a woman of color in the southern antebellum U.S. As the daughter of two free people of color, one of whom was a prominent New Orleanian to whom Marie's mother was a placèe, Marie was also known as a gens de couleur. Laveau considered herself a French subject, though being born in 1801, just two years before the Louisiana Purchase, she was technically an American for the majority of her life (C. Long 25-8). She enjoyed some notoriety, even on a national level, during her lifetime, as evidenced by various newspaper reports of "sightings" of the intriguing folk celebrity. Upon her

\footnotetext{
${ }^{45}$ Plaçage was an arrangement that developed under French rule, where free women of color became the concubines of wealthy free men in the region. Not all of the men in these arrangements were white, and the arrangement was considered a long-term, contractual agreement. The men usually provided a living for their placèes, even though they were often married and providing for their own wives and children. The related custom of quadroon balls provided a way for free women of color to be introduced to wealthy men who sought placèes (Cheung 8-10).

${ }^{46}$ City leaders in New Orleans in the late $19^{\text {th }}$ and early $20^{\text {th }}$ century, concerned about prostitution across the city, decided to legalize the practice in a segregated section called Storyville. The goal was to create a place for the "valve" of male sexual tension to be "released" without harming the reputation of the rest of the city. In fact, Storyville actually helped to cement the reputation of the city as a "sin city." (A. Long 18) ${ }^{47}$ Long surmises that Laveau - like many other slaves and free people of color-practiced some combination of African spirituality intertwined with Catholic ritual, describing this as a uniquely New Orleans practice that combined African and European elements (118).
} 
death in 1881, laudatory obituaries with extensive biographies were published in the New Orleans Time-Picayune ("Death of Marie Laveau"), and the New York Times ("The Dead Voodoo Queen"). Nonetheless, written records of Laveau, especially during her younger years, are sparse; some confusion remains even regarding the body that inhabits the tomb that bears her name. Her daughter, also named Marie Laveau, was reportedly a powerful Voodoo Queen in her own right and was interred in the family tomb after her own death (C. Long 209). This leads to some speculation that, in a deliberate attempt to keep her legacy and physical remains free from unwelcome attention, the original Queen Laveau is buried in St. Louis Cemetery No. 2, while it is actually her daughter whose body inhabits the famous vault that has become one of the key stops on sightseeing tours of the city. ${ }^{48}$

In spite of the dearth of verifiable details about Marie Laveau, it is confirmed that she led various Voodoo dances and rituals in New Orleans during her life. In question is the matter of scope and scale of these performances, but again, even during her lifetime, the rhetorical manifestation of the Voodoo Queen was situated firmly in the center of a popular and colorful characterization of a vital Voodoo community that resisted hegemonic control. One of the most popular accounts of her involves her prominent role in the regular Sunday gatherings of slaves and free people of color at Congo Square in the black neighborhood of Trème (Ward 4-6). ${ }^{49}$ This type of ethnocentric assembly was officially illegal, but it continued throughout the eighteenth and nineteenth centuries, and those who participated often did so while gathered in the area for market, or under the pretext of funerary rituals (New Orleans funerals were embraced as a cultural celebration

\footnotetext{
${ }^{48}$ This rumor has been debunked by Long, but still persists (209).

${ }^{49}$ While Voodoo rituals were often practiced in other spaces, and Laveau likely did not lead rituals on these Sundays, Congo Square was widely known as the site of weekly slave dances with African drums and performance, which became accepted as a common sight in eighteenth and nineteenth century New Orleans (C. Long 40-46).
} 
in part because they remained legal under the code noir, which permitted the communal gathering of blacks for purposes of burial) (C. Long 40). Ironically, a requirement of the black codes that people of color take Sundays off for Christian worship was another legal loophole that allowed such gatherings to happen somewhat consistently in this era (Roach $58-60)$.

The Sunday practices of African dance and song were generally well tolerated in the city during the early years of American settlement, and in short order, white onlookers also began to gather in Congo Square on these days, simply to watch the spectacle (Ward xxii). Although biographer Carolyn Long concludes that Laveau did practice Voodoo and did so on a regular basis from her home, as well as presiding over St. John's Eve ceremonies, the popular reports of Marie Laveau leading elaborate public rituals and performing feats of spell casting and conjuring may have been embellished or perhaps entirely fabricated from popular stories of Haitian Voudou Queens (97). These were nonetheless transmitted as fact by newspapers and via word of mouth during this time and for generations after her death. Accounts of the rituals at Congo Square included admiring descriptions of Laveau's haughty walk, beautiful face, boldly bright tignon, and lascivious dances with a giant snake, as she conjured the spirit of The Great Serpent, or "Le Grand Zombi" (Ward 7, 20).

These representations of Laveau cast her as a woman at once empowered with sexual authority (the symbolism of dancing with a snake and managing to conjure and possess its powers a testament to mysterious feminine abilities) and yet willingly subservient to a fearsome masculine figure of bestial dominance - typical stereotypes for many women of color then, and even now. The authority with which she was imbued by 
her society seems on one hand to have been sited in Laveau's ethnocentric attachment to Voodoo and her knowledge of the tradition, as well as in the aristocratic lineage on her father's side, but Laveau's representation is nonetheless channeled through stereotypical perceptions of women of color as Jezebels, "bad girls" who were beautiful by Eurocentric standards, and at the same time racially ambiguous and manipulators of men (West 462). Few references to the young Laveau fail to include a lengthy description of her as exotically beautiful (a 1909 article in The Evening Star, for instance, describes her in her youth as having "creamy skin," "a queenly carriage" and "features of the Egyptian type" [W. Curtis]). Most accounts also include some mention of her public dances, leaving a lasting impression of the Voodoo Queen as a subversive sexual suspect with enough connection to a "primitive" Afro-Caribbean tradition and culture to pose a threat to white Christian society.

As Laveau's legend grew, anecdotes attesting to her political influence likewise increased. She was rumored to have the power to make judges grant pardons, and even to make whites do her bidding (Ward 7-8, 14). Tales persist, for instance, that portray Laveau using her magical energy to subdue unfriendly police patrolling Congo Square during a Sunday Voodoo gathering (Ward 4-5). In these kinds of stories, the authority of Laveau is established in her ability to possess the powers of hegemony as if they were her own, flaunting control over the law and those who represented the system. Even malicious rumors that ran rampant about Laveau—contentions that she was not magical at all, that she was simply a masterful manipulator and extortionist who blackmailed important people — nonetheless highlight her reputation as a potentially dangerous woman who held so much influence in New Orleans society that few dared to cross her 
(Ward 73). The image of Marie Laveau as the supreme authority of the underbelly of New Orleans is complicated by a parallel representation of her as a woman who gained power by conceding it. Rumors sometimes attributed Laveau's special position in New Orleans society to her willingness to acquiesce to the power structure and to pay homage in her own right to the major players of New Orleans politics (C. Long xxiv). She was rumored to be able to practice Voodoo openly only because she made a secret pact with Catholic Priest Père Antoine. The story was that by faithfully attending mass at Saint Louis Cathedral and convincing others to attend, Laveau's rituals would have the support of the Priest, who would also assist her in championing rights for people of color in New Orleans (Ward 20).

Alongside accounts of Laveau's audacity and her exotic beauty existed disdainful invectives against her as a fraud. A number of newspaper articles during and after her life that reference her role in Voodoo practices promoted the notion that Laveau's performances were nothing more than grotesque public spectacles, and that those who followed Voodoo in a serious way were simply providing proof of the shameful and primitive ignorance that pervaded the African continent (W. Curtis). The obvious contempt that permeates some of the descriptions of Laveau during her later years and in the years after her death is directed toward dismantling the notion that she had any legitimate status as an influential player in New Orleans society. An 1873 “sighting” reprinted in the evening edition of Richmond, Virginia's Daily State Journal depicts the elderly Laveau as a fallen figure:

Marie Laveau, the New Orleans Queen of the Voudous, appeared as a spectator in the lobby of the criminal court in that city the other day, 
attracting a good deal of attention. The Times says: 'She was dressed in all the soiled frippery of an impecunious princess, with her rather commanding form encircled by a red shawl and a faded yellow madras, wrapped in the form of a turban, around her head.

Sarcastically characterizing Laveau as a dirty, poverty-stricken "princess," the article concludes with lines from the final stanza of Poe's "The Raven": "Her eyes had all the seeming/Of a demon that was dreaming" ("Marie Laveau"). An ominous and everpresent symbol of despair that is the black bird of Poe's poem, Laveau plagues white society with her very presence. The comparison of the Voodoo Queen to a black bird is obviously a racial slur, but it also serves to reduce her to a symbolic black figure of danger - a troublesome and disturbing pest who persists in reminding whites of her presence, however unwanted she may be.

The notoriety of Laveau created and reflected a desire in the established power structure to contest her esteemed position in New Orleans society and/or to render her socio-cultural status more comprehensible. By degrading her image or questioning the lasting value she held during her life, juxtaposing her with animal imagery and emphasizing her titillating performances, the stories about the Voodoo Queen insinuate that Laveau's influence as an empowered woman of color was contingent upon a set of feminine wiles and suspect racial heritage that somehow afforded her privilege and status that she did not deserve. While it is impossible to know how many people actually followed her, and how many of those people were influential in New Orleans society, that Laveau was frequently the object of public speculation is not in question. 
The conviction that Laveau could make anything happen that she wished (whether born of spiritual beliefs, wishful thinking, paranoia, or misogynistic and/or racist cynicism) positioned her as the embodiment of something inspiring or of something quite threatening, depending upon the situation (C. Long 39-40). Even in a city known for its tolerance of practices and subcultures that defied the typical expectation for southern antebellum societies, the agency attributed to Laveau was exceptional. As the site of competing claims on behalf of whites, blacks, and free people of color, Laveau figured the transgressive power of liminality in an American south that rejected the tripartite system, whose fears and methods of control were manifested in the transition of New Orleans into a more comprehensively bi-partite southern Jim Crow order as the twentieth century further entrenched the binary of black-white racial caste into popular consciousness. Whether Laveau did all she was rumored to have done is unknowable, but the lasting power of her legend has verifiable evidence that requires no more than a twenty-dollar ticket to St. Louis cemetery No. 1.

\section{Sacred Spaces and Suspect Spirits: Paying Homage in the City of the Dead}

Laveau was interred in Saint Louis Cemetery No. 1 after her death in 1881. In December 2013, her famous tomb was the object of a confounding act of vandalism, when it was painted completely pink. In the middle of the night, some unknown person or persons snuck onto the cemetery grounds and covered the Voodoo Queen's tomb in a coat of latex paint the color of Pepto-Bismol. Her tomb, like many others in the cemetery, was crumbling and quite fragile. Unlike other tombs, however, Laveau's was usually covered in graffiti. The letters "XXX," written in lipstick, marker, red brick, and nail polish, among other mediums, were scrawled on every side of the structure (fig. 2). 


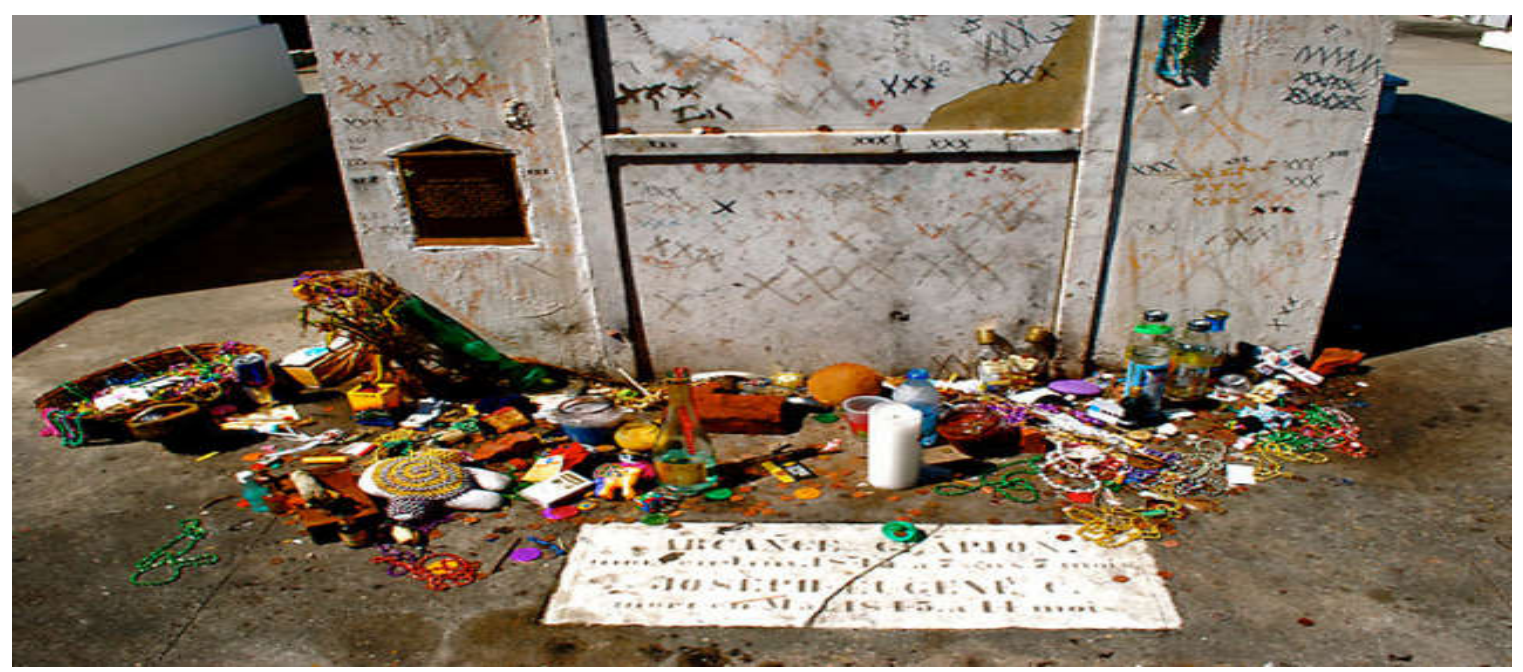

Fig. 2 Marie Laveau's Tomb, before it was painted (Danger)

This symbol, combined with tokens of appreciation such as Mardi Gras beads, money, tobacco, or alcohol, was purported to invoke the assistance of Laveau's powerful spiritthough the gifts were usually stolen in the middle of the night (Butler 114, 138-9; Ward 12-13). So, when the structure was painted in 2013, authorities could not ascertain whether the unknown vandal was attempting to deface or improve the monument, but the damage was done nonetheless, and not just to the tomb.

While the paint was eventually removed and preservationists were hired to restore the structure to its original state, the cemetery has since changed its policy on public access. Madame Laveau's resting place was officially re-opened on October 31, 2014 just in time for Halloween tourists-but Saint Louis Cemetery No. 1 itself is no longer free and open to the public, by order of the Archdiocese. The only way to visit Laveau now is to purchase a ticket for a guided tour of the cemetery - a privilege for which select private tour companies pay the Diocese yearly, and for which individuals must pay twenty dollars (McCormack). Those who seek access to the Voodoo Queen's powerful 
spirit must now pay tribute not just to Laveau, but to a mediator whose claims to authority over the space supersede all other interests.

The commoditization of Laveau's final resting place entails not just a twentydollar fee from visitors, but also includes a mandatory lesson in history from a limited selection of Archdiocese-appointed authorities on sightseeing in New Orleans who have exclusive access to the business of narrating the life and death of Laveau for the public. The Catholic Church has effectively used the prominence of Laveau's grave to exact a kind of tribute in exchange for the tourist version of spiritual communion, controlling how she is visited and how her history is narrated. This segregation simultaneously removes transgressive potential from Laveau's tomb while it implants a rigid hierarchical structure based on Eurocentric religious class interests, regenerating a social order that privileges a controlled and comprehensible relationship with history as a commodity.

A gratifying workaround that has been implemented by the local community since Laveau's tomb was isolated from the public was to simply erect of a new monument to her outside the cemetery. In 2015, Ricardo Pustanio, an artist with ties to the Voodoo community in New Orleans, constructed a nine-foot tall statue of Laveau that operates as a surrogate space of homage for the tomb and is housed at a local spiritual center, where visitation is free and open to the public. This action has had significance beyond filling the spiritual and communal gap left by the closure of Laveau's tomb to the public, as Pustanio used the opportunity to emphasize Laveau as a symbol of black empowerment above all, purposely making Laveau's skin a dark shade of brown. There is no way of knowing whether Laveau was actually light-skinned or dark-skinned, but the descriptions of Laveau as light-skinned in popular historical depictions have nonetheless altered the 
meaning of her power by making a point to describe her as Creole, mulatto, quadroon, or octoroon, rather than black. Laveau, in fact, has almost never been described as a darkskinned woman (Hayoun).

Voodoo Practitioner and co-collaborator on the statue, Sally Ann Glassman, spoke of the darkening of Laveau as an act that the creators felt was "respectful," adding that the figure of the Voodoo Queen as a decidedly Afrocentric symbol of authority reflects the purpose of Voodoo for the black community: "Voodoo had the power to look beneath the surface of things to find a spirituality that couldn't be destroyed by the slavemaster's whip. That's what we're honoring" (Hayoun). Though the Catholic Church in New Orleans has claimed authority over Laveau's body and her legacy, the lasting power of the Voodoo Queen as a transgressive figure of authority nonetheless opens a (non)site of possibility for asserting meaningful challenges to the hegemonic appropriation of exceptional/marginal spaces of community empowerment. In reclaiming the significance of Laveau's legacy for people of color and re-situating it outside the walls of the cemetery, the Voodoo community in New Orleans has claimed agency over its own representation and has also countered the commoditizing apparatus of the tourist industry by inscribing new, perhaps even more significant meaning for Laveau outside the paternalistic Eurocentric structures that continue to reproduce the binary between civilized and savage in the privileging of Catholic-sanctioned modes of reverence over Afrocentric ways of honoring the dead.

As biopolitical regimentation has asserted itself in the modern nation-state by declaring juridical authority over the bodies of human subjects (through slavery, imprisonment, institutionalization, etc.), and by constructing a binary between the realm 
of the living and the realm of the dead through the creation of cemeteries, the funeral traditions of New Orleans' people of color have maintained conscious liminality from within these constraints to embody time, space, and spiritual meaning through performances of grief and remembrance that resist bureaucracy. Joseph Roach discusses the origin of the New Orleans "cities of the dead" as they came about with the development of European rationalism, which required a devoted public space for cemetery internment and segregation of burial spaces away from the heart of cities. In the traditions of black New Orleans funerals, however, the dead are welcomed to enter the spaces of the living. They are not seen as departed souls, but as longtime friends (Roach 61-2).

These funerals have become renowned over generations as celebratory events with parades, music, and dance. The infamous "second line" jazz bands gather amongst the procession of mourners to perform rowdy, festive themes as the group leaves the cemetery and begins the street parade that signifies transition between past and present. While the dead are still invited to dwell amongst the living, and the wisdom of the ancestors is embodied in the living through folklore and ethnocentric traditions, and even in the continual re-configuration of various traditions, the funerals nonetheless function as much to look toward the future as to remember the past. Roach describes "the moment of transformation," where mourners shift from lament to celebration. This moment is referred to as "cutting the body loose," and has been part of African funeral ceremonies in New Orleans since the eighteenth century (61-2). Creating a new tradition for honoring Laveau allows for alternative conceptions of governance and democratic space-making in New Orleans, where the Diocese's commodification and historical reconfiguration of 
Laveau's legacy in the name of exception has effectively "cut the body loose" and inadvertently opened new spaces in which to celebrate and honor ethnocentric empowerment as necessarily enacted from the margins.

\section{Biopolitical New Orleans: The All-American Host}

From the early days of New Orleans, the city and the people who gave it much of its tourist appeal—free people of color, African transplants, Haitian refugees, and their descendants - were expected to maintain a position of marginality simultaneously with a position of power and intrigue. The uneasy balance struck between free people of color and the controlling forces in New Orleans during the early days of U.S. occupation began to falter during the mid to late nineteenth century, as the oppressive forces of white dominance continued to persist against the local norms that had long made New Orleans a space of exception for free people of color. As U.S. control and its bi-partite system of racial divide began to span generations and the semblance of even marginal empowerment for people of color under French and Spanish rule became a distant memory, the governments of the Jim Crow south continued to justify more violence and oppression under the guise of innocuous state statutes. The freedoms that New Orleans had at least minimally afforded as an exotic simulacrum of international intrigue became, essentially, a daily performance of blackness for the entertainment of outsiders, under the watchful eyes of local authorities whose allegiance to the white hegemony helped to eventually ingrain the deep binary between black and white that marked the homogeneity of American racial caste in the United States in general (Roach 253-5).

A study of the economic and social histories of New Orleans reveals a city that has long struggled to define itself, seeking to capitalize on the public fascination with its 
multi-ethnic populace while also succumbing to mainstream political notions of capitalist growth that have proven to be both short-sighted and ineffectual. J. Mark Souther examines the historical trajectory of the economy of New Orleans, analyzing the effects of the city's attempt to diversify in the 1980s into more industrial sectors and to stake a claim in the booming oil business. The ultimate failure of that experiment highlighted New Orleans' near-absolute reliance on tourism as its main commodity. Even in its early days, New Orleans held power as a tourist destination, and this identity only became more entrenched as tourism grew (Souther 117). Against its own best intentions, the economy of New Orleans developed into one that was uncomfortably reliant on the continued presence of outsiders, the consequences of which entailed continuing to perform for these visitors (117). After the city fell into a severe recession in 1984 due, in part, to its failed attempt to enter other sectors, the desperation to embrace and further perpetuate its image as an ideal tourist destination became the prime objective of community leaders in New Orleans (114).

As city leaders of the eighties looked toward expanding the tourist base, the problem they encountered was one of branding: "The retention of a distinctive, traditional New Orleans style served as an ideal springboard for cultural tourism," Souther explains, "[y]et New Orleanians had failed to assert themselves for decades, allowing outsiders to define and adapt the art form" (122). In its desire to appeal to suburban tourists, the material reality of New Orleans had to be changed. With a black majority population, the city constantly defended against perceptions of itself as a crime-filled danger zone of desperate, poverty-stricken blacks. Souther describes how the French Quarter became insulated from the rest of the city — especially the Ninth Ward — by city officials, who 
destroyed large portions of the Tremè neighborhood with traffic highways that ran through the residential sections, effectively disconnecting it from the French Quarter tourist attractions and breaking up the historic black community via injections of massive urban traffic byways. The city also began to construct larger civic buildings in Tremè in an attempt to gentrify it, making it all but impossible for poor residents to afford to remain in their neighborhood (134-5):

The rape of Tremè in the interest of tourism-oriented urban revitalization demonstrated not only the limited capacity of tourism to revive the inner city but also leaders' skewed priorities, in which a black neighborhood was deemed unworthy of preservation and forced to serve as an adjunct to a white tourist area. (136)

Alternately embracing its population of black citizens or hiding them away as the tide of popular opinion demanded, New Orleans could not easily locate itself in the spectrum of tourist models. Neither island resort, nor shopping mecca, nor kid-friendly theme park, it became an early exemplar of "heritage tourism," beautifying its historic neighborhoods and highlighting its multi-cultural heritage, along with a hefty revamping of its French Quarter to suit white, suburban tastes (128-9)

Building up its waterfront into a more commercially viable neighborhood was a general trend amongst southern cities in the 1970s and 1980s, and New Orleans followed this trend, as well (Souther 128). ${ }^{50}$ The irony of this retooled cultural and social landscape, however, is that New Orleans was so successful at shaping itself to the tastes

\footnotetext{
${ }^{50}$ Though the Jim Crow era had been a major problem for New Orleans, as a city known to be an exception to many southern mores, the shift in the 1970s to a less obvious form of institutional racism and socioeconomic segregation effectively made the "southern problem" of New Orleans invisible, allowing it to fashion itself as the "historical," open-minded New Orleans of old (Souther 125-8).
} 
of mainstream America that it became an attraction in Disneyland's Magic Kingdom. A replica of the French Quarter became one of the theme park's most popular attractions, going so far as to hold regular Mardis Gras parades. This simulacrum, in fact, influenced public perception about New Orleans so much that visitors who were inspired by their experiences at Disney's iteration to visit the real city were disappointed by the less pristine and decidedly more complex original version. Consequently, New Orleans reconfigured itself anew, scrambling to match the Disney version of itself. As a hyperreal site of heritage, this newest New Orleans was one among many whose urban planning capitalized on the marketability of nostalgic constructions of a utopic historical past. Some such districts are based in reality, while others are not: "[F]abricated heritage attractions such as Atlanta's Underground and St. Louis's Gaslight Area" Souther explains, are examples of new outgrowths who took their cues from the Disneyland model of the French Quarter in a bid to generate a more saleable history (128-9). The city of New Orleans as an exceptional space is reduced by this capitalist competition to exist as merely one among many "unique" heritage tourist spaces seeking to trade in the stock of a simplified past via a whitewashed signification of authenticity that relies upon the servitude of a large population of willing performers.

The New Orleans tourism push has expanded considerably since it gained traction in the eighties, becoming the kind of large-scale enterprise that requires complicity from its ethnically diverse populations, who are a significant part of the New Orleans mystique. The city paints itself as an exception, and by extension, the people living in New Orleans are bound to this characterization of the city as exotic and exceptional-a dazzling, eccentric spectacle of culture and ethnicity. Living in a tourist destination, 
especially if it also provides income for a resident, involves a continual awareness of the "tourist gaze," and a heightened consciousness of the expectations of outsiders who expect some gratifying spectacle of "authenticity" in exchange for their patronage (Urry 63, 145-6). ${ }^{51}$ For black residents especially (all the more so, after Katrina), the city's tourist-host relationship has the potential to turn their familiar spaces into particularly objectifying arenas. As "the only inhabited city that exists simultaneously as a national historical park," Joseph Roach explains the dissolution of difference in New Orleans between the simulation and the hyperreality of life in the city: "Unlike Colonial Williamsburg or Disney World, each of which it resembles in certain respects, the Crescent City's picturesque inhabitants do not change clothes and go home at the end of their working day to what they erroneously have come to regard as the real world" (Roach 180).

Lynnell Thomas has compared the racially-driven components of tourism in New Orleans via its marketing campaigns and tours, both before and after Katrina, describing the pre-Katrina tourism as performed blackness that was packaged with the product of "heritage." Defined simultaneously by a mix of "desire and disaster," the tourist gaze rendered black New Orleanians invisible, hidden behind the façade of whitewashed history and docile performance:

On the one hand, tourists were encouraged to think that they were experiencing and celebrating black culture by eating Creole cuisine, listening to jazz music, and sharing in anecdotes of quadroon balls and secret voodoo rites. On the other hand, tourists were directed to adopt the

\footnotetext{
${ }^{51}$ See John Urry's Tourist Gaze for more on the relationship between visitors and inhabitants in tourist destinations.
} 
white supremacist memory of slavery and black culture that views the Old South with a sense of loss and nostalgia. (751)

Tourism in spaces like New Orleans relies upon "the omnipresence of African Americans in the service industry, whose performance of 'happy servitude' is mandated by the conventions of the local tourist economy" and requires a subservient brand hospitality that, in this space, is inherently racialized, even as it operates via the colorblind ideology of global neoliberal capitalism (751). The restyling of former sites of black degradation and dehumanization in New Orleans (such as slave quarters) into tourist-friendly restaurants and hotels has contributed over the years to a restructured historical milieu where "tourists were signaled to consume or gaze upon black culture, without the uncomfortable acknowledgement of the history of slavery [...] New Orleans tourists, then, became acquainted with a representation of blackness that left the actual black New Orleans invisible" (751).

The tourist economy and color-blind universalism driven by neoliberal markets that helped erase black culture from the historical, social, and economic positions of authority in New Orleans before Katrina contributed to the resulting sense of collective national shock at the neglect of the federal and state governments when media attention finally focused on the plight of blacks who were stranded in the city. As it came to resemble what so many described as a "third world country" within the nation, the image and rhetoric of the U.S. as an orderly space of democratic stability was exposed as a lie. Moreover, what Katrina exposed in the treatment of New Orleans survivors was an undeniably racialized class hierarchy. Perhaps the shock of the hurricane was paternalistically channeled into sympathy or guilt, as the post-Katrina tourist industry 
now thrives, in part, because the horrifying imagery of the hurricane invited the eyes of the nation to gaze upon the floating bodies of its victims and in so doing, produced new objects of desire.

Thomas writes that the same narratives of desire and disaster that pre-Katrina tourists consumed have arisen in the post-Katrina tourist campaigns. One trend has tended to adopt a colorblind approach to the disaster that emphasizes the city's recovery as a joint effort. Signifying the hurricane as a community tragedy from which the community as a homogenized space of unity — rich and poor, white and black alike — has joined together to overcome the tragedy, this narrative tends to elide the material conditions of the city outside the tourist locale and neglects the wildly disproportionate effect the catastrophe had on poor blacks (759). The other trend has devoted itself to a "white savior" narrative that foregrounds the horror story of the hurricane and typically includes tours that include a brief visit of the Ninth Ward destruction. These forays into the shattered habitats of citizens who no longer have the means to come back and rebuild encourages tourists to gaze upon the ruins of the storm via a sympathetic platform that diminishes and simplifies the conditions of the hurricane and its aftermath, "present[ing] African Americans as victims awaiting the action and expertise of whites to intervene on their behalf" (759). Erasure in this instance, Thomas explains, has as much to do with the fact that no blacks are living in much of the tour routes' neighborhoods as it does with the over-simplification of the social conditions in New Orleans (758-9). The social, cultural, and historical deaths that have occurred in the city since the disaster are belied by the deployment of Katrina’s "ruins" as simplistic stand-ins for an imagined resurrection that 
the tourist industry constructs by implementing variations of the pre-Katrina tour narratives that package black performance as a non-threatening consumer commodity.

While tourism has, at times, struggled to sustain the city, Hurricane Katrina has revitalized the ability of New Orleans to capitalize upon its status as an exceptional place, with campaigns now directed toward reconstruction narratives and tours devoted to sightseeing among the ruins. And now, with Saint Louis Cemetery No. 1 open only for paying visitors, the commodification of the exceptional status of the space has extended to the most famous of the cities of the dead, as well, where rumors of lurking criminals might have otherwise kept visitors away. The disaster of Hurricane Katrina has been implemented for use as the latest incarnation of the exceptional status of the city and its majority black population in a way that reveals the everyday machinery of the biopolitical regime. In the erasure of the material conditions of the hurricane in favor of idealized representations of empowered black marginalization that disguise reality, the potential for normalizing totalitarianism is achieved through the status quo of neoliberal biopower. New Orleans has remarkably readjusted to this "new norm" where the black population of the city has decreased by almost 10 percent. As of 2013: "Nearly 100,000 fewer African Americans live in the city today than in 2000. Around 11,500 fewer white residents live there" (Nowakowski).

As the lives of citizens have become subsumed by the state of emergency and the new norm of New Orleans as a tourist space is dependent upon either the invisibility of Katrina's black survivors or the deployment of them as extensions of the hurricane's destruction, in a sense the pre-Katrina imperative to perform servitude and regenerate the city "as a simulacrum of itself, apparently frozen in time, but in fact busily devoted to the 
ever-changing task of recreating the illusion that it is frozen in time" (Roach 180) still stands, but depending upon who is performing New Orleans as "frozen in time," black citizens may alternately find themselves living and working in an idealized version of the Old South or performing as fossilized artifacts of the 2005 disaster.

The continued economic dependence upon the tourist industry in New Orleans, especially after the hurricane, reflects a mechanism through which biopolitical control over the populace is achieved. This docility, as Foucault explains:

would not have been possible without the controlled insertion of bodies into the machinery of production and the adjustment of the phenomena of population to economic processes. But that was not all it required; it also needed the growth of both these factors, their reinforcement as well as their availability and docility; it had to have methods of power capable of optimizing forces, aptitudes, and life in general without at the same time making them more difficult to govern. (History of Sexuality 141)

A marginalized community whose agency in the modern era has typically been located in its ability to vote for black politicians who nonetheless devote their careers to the tourist agenda that sustains a generations-long status quo of racial hierarchy, the Foucauldian docility is embedded in the implicit requirement of performing exotic exception in order to participate in society, and further, being expected to perform marginalization, or even victimhood as part of this dynamic. The unspoken mandate to perform marginalization in order to facilitate an ecosystem of hospitality for outsiders, in effect renders the performance indistinguishable from the reality and illustrates the docility of the 
individuals whose insertion into this "machinery of production" is built upon and

maintains their reliance on it.

\section{Neoliberal Norms: Democracy, Totalitarianism, and The Emergency}

The popular rhetoric of the Katrina disaster suggests that New Orleans is returning to some manifestation of her pre-Katrina self, but it also suggests that this is what the local, state, and federal governments aim to do. Many feel differently, however, asserting that the New Orleans they had always known was never meant to be brought back after Katrina. ${ }^{52}$ Certainly, the massive investment of money both federal and private in the city's French Quarter and the neglect of the Ninth ward suggests that the efforts to remake New Orleans are designed not to resurrect the city so much as to refashion her in the image of a more homogenous and comprehensible town. ${ }^{53}$

Naomi Klein has written extensively about what she refers to as the "shock doctrine," which she asserts has become a fundamental facet of capitalist societies, and which is an outgrowth of "disaster capitalism," whereby any major catastrophe-manmade or natural — becomes the ultimate source of potential for the growth of corporate control. Klein examines a number of major disasters across the world, including Hurricane Katrina, and explains the methods of corporations who, abetted by federal and state governmental agencies, seize the moment of collective shock and paralysis to a community following a major disaster to pass legislation that will permanently change

\footnotetext{
${ }^{52}$ Perhaps most famously, Spike Lee's documentary on the hurricane contained interviews with citizens of New Orleans, who stated that they believe the levees were intentionally destroyed in the poor, black districts in order to destroy the less desirable neighborhoods while saving the more affluent areas. Lee himself has suggested as much in interviews, as well (Lee).

${ }^{53}$ In a December 2013 interview on PBS's Newshour, titled, "Can the Lower Ninth Ward Ever Recover from Katrina?" the story's summary poses the question: "Years after Hurricane Katrina devastated the Lower Ninth Ward of New Orleans, a debate now rages in the city; with so few residents returning to the Lower Ninth, does it even make sense to redevelop the community at all" (Frey)?
} 
the basic operating principles of the area to favor corporate rebuilding, drastic cuts in public assistance, and, when possible, restructuring and downsizing of public institutions like schools and police departments. As residents of the affected communities are preoccupied with finding a way to simply survive the immediate aftermath of a largescale catastrophe and have scarcely begun surveying the toll of the disaster, their lives, homes, and governments are being overtaken by outside interests, with little to no oversight on the part of regulatory bodies.

Increasingly, regulatory oversight of any number of public institutions is being taken over by private, non-state actors whose bottom line is economic profit. This process of privatization is referred to as "private transnational governance":

[T]hese organizations are illustrations of a growing market of non-state processes in which issues are defined, rules are made, and compliance with these rules is monitored. At the same time, they are indicative of a shift in the strategies of non-state actors away from lobbying governments to establish certain international policies and rules, toward setting and implementing those rules themselves. As far as their output is concerned, the governance processes that result from this strategic shift resemble international regimes with the important difference that it is not states, but non-state actors who generate the "principles, norms, rules, and decisionmaking procedures," and the expectations associated with them.

(Dingwerth 608)

While these organizations are not officially recognized as governing bodies by the state, PTGs have the power to indirectly govern large portions of the public sphere and to 
control day-to-day life for citizens. The U.S. has been steadily moving away from asserting its responsibility over regulations for private companies that deal in large-scale public operations and allowing, or even paying, PTGs to do the job instead. One of the major responsibilities for which PTGs are tapped is the job of defining key terms within the regulatory statutes of various industries. Things such as creating sustainable environmental protocols for industrializing in developing nations; monitoring international banks and trade; determining parameters for the assignment of international credit ratings; and devising methods and procedures for reconstructing disaster zones or managing rescue efforts, are typically handed off to private actors via government contracts (608).

The rise of neoliberal policies since the 1970s articulates the underpinnings of what drove government-funded relief efforts in the aftermath of Hurricane Katrina. Using David Harvey's definition, neoliberalism is defined as a political philosophy that seeks, "the maximization of entrepreneurial freedoms within an institutional framework characterized by private property rights, individual liberty, unencumbered markets, and free trade. The role of the state is to create and preserve an institutional framework appropriate to such practices" (The Condition of Postmodernity 22). Under this model, the United States has become increasingly totalitarian in the establishment of government policies in any number of domestic and global sectors, in spite of the fact that these decisions often violate the law and/or Constitution, ignore the disagreement and outright resistance of the citizenry to many of their objectives, and display an audaciously obvious incongruity between the stated objective and the eventual outcome (the unilateral declaration of war in Iraq offers an example). As it is commonly noted, the United States' 
spread of democracy has taken some rather undemocratic forms, and the use of massive amounts of federal and state tax monies for completion of these missions is directly at odds with the "individual liberty" pursuit that is supposed to be at the heart of neoliberal philosophy.

The state dispersed federal funds to numerous private agencies for rescue and rebuilding efforts in New Orleans, but it did not regulate those funds or oversee the rescue and rebuilding operations in the Gulf region. 1.5 million evacuees were sent all over the country to live with strangers (Miller 126), while those who were able to return or somehow managed to stay in the Gulf region were housed in trailer communities on the margins of their city, with some sent to trailer camps in other states entirely. These conditions largely remained unchanged, as years passed and rebuilding efforts exposed an undeniably uneven reconstruction mission. While evacuees awaited relief that they were promised and upon which they were reliant to rebuild their lives (or even merely to survive, as the hurricane took everything they owned), they lingered in FEMA trailer parks with no choices and nowhere to go. And yet:

By the third year post-Katrina, with many families still living in these trailers, the government put a full-stop deadline for people to vacate them or, ironically, to exercise an option to purchase the trailers through online government auction for $\$ 5,000$ to $\$ 12,000$ [...] Although FEMA officially stated that each trailer cost approximately $\$ 14,000$ to $\$ 20,000$ to manufacture, the Government Accountability Office (GAO) estimates that the costs incurred for each FEMA trailer could be as high as $\$ 229,000$. That is, the government paid nearly $\$ 230,000$ per trailer to the contractors 
who built and delivered them, Halliburton among them. The GAO found that FEMA profited from a total of $\$ 30$ million in fraudulent payments for trailer maintenance and cited examples of rigged bids and excessive payments on their trailers. (Adams, Hattum, and English 628)

Blackwater, too, was given a federal contract, and within days of the hurricane's landfall had begun "patrolling in armored cars with heavy artillery" (629). Other companies, like Bechtel, were given no-bid contracts. Bechtel actually won its contract to supply temporary housing before the hurricane hit and long before the levees had broken (629).

The corporate contract has come to power and exercised its authority in various branches of the government in a host of ways. In 2006, for instance, Red Cross partnered with Wal-Mart to form a disaster response coalition for Katrina survivors. Even the job of awarding government-funded FEMA contracts after Hurricane Katrina was, itself, contracted out (Klein 416-417). The expenditures of the government in the wake of Katrina reflect not just a galling lack of oversight, transparency, and humanity in the workings of a system designed to frustrate attempts to use it in the service of human need, but a particularly brazen controlling force interjected into the federal government that cannot be sited in the White House, but more likely in an empty office at 1209 North Orange Street in Wilmington, Delaware..$^{54}$

The insidious nature of these contractual relationships between private and state agencies is reflected in the contradictions between the names of the organizations and the activities they actually perform under the guise of "disaster relief." In 2006, for instance,

\footnotetext{
${ }^{54}$ Delaware's tax laws have given it the status of a domestic tax haven for hundreds of thousands of corporations, who use "shell companies" to avoid paying taxes. 1209 North Orange Street in Wilmington is the address used by over 285,000 companies, including interests owned by both of the Presidential candidates in 2016 (Wayne).
} 
a group of major CEOs came together for a conference. The group called itself Partnership for Disaster Response. Many of them had been awarded contracts the year prior to rebuild New Orleans after the hurricane, and Klein notes that their goal in holding this conference was to further their economic interests in the hurricane region and in the business of disaster recovery, in general. This, according to their own proceedings, included determining a course of action to thwart the "mission creep" of nonprofit groups in New Orleans and other disasters: "Apparently charities and NGOs were infringing on their market by donating building supplies rather than having Home Depot supply them for a fee" (Klein 418). Megan Reid discusses public perceptions of "deservingness" that were applied to the black survivors of Katrina, discussing the particular difficulty Katrina's poor, black survivors faced in acquiring even the most meager assistance. Through what she calls "temporal domination," the government and its contracted agencies complicated and delayed processes for relief for displaced New Orleanians, some of whom have never received any assistance at all, in spite of qualifying, because of policies of obfuscation and a lack of communication with evacuees (Reid 745-750). The disgraceful case of FEMA's disaster profiteering outlined above is another prime example of the neoliberal approach to public assistance. They, and other government and private agencies operated with a bottom line to rid the city of a population that was, in the eyes of a system driven by market concerns, an undeserving and disposable population (744).

\section{Left to Die: Surplus Populations, Relief, and "Deservingness"}

The response to Katrina was the most militant response to a disaster in the U.S., involving unprecedented numbers of military personnel on the ground (Tierney and Bevc 
43). In fact, Klein points to disturbing parallels between the behavior of contractors in New Orleans and those in Baghdad, as many of the same corporations have been involved in rebuilding and security in both areas (411-414). The justification for this vast militarization of the city is intimately linked to the politicized framing of the New Orleans rescue efforts as dangerous missions in hostile territory. The story of the disaster in New Orleans shifted almost immediately from narratives about the hurricane and its destruction to sensational tales of chaos and violence. As the media began to focus less on the suffering and need in the region and more on the criminal behaviors they located (or seemed to locate), public perception of the catastrophe became increasingly defined by antipathy or indifference toward those who had been most affected by it.

News agencies frequently get news from each other, and because so many of their reports are often so similar, they seem to corroborate one another. This fallacious veracity substitutes remarkably often for genuine evidence and firsthand reporting; thus, the negative perceptions attached to emergencies that affect large populations of color (eg: black looting and violence) become perpetuated and entrenched in the popular storylines of such occurrences (Tierney and Bevc 41 ). ${ }^{55}$ Many early news reports did not remotely reflect the conditions of New Orleans or the behavior of the people who survived Katrina. For that matter, these reports did not even reflect typical behavior of the victims of any disaster, but rather constructed a "civil unrest" framework of the disaster, emphasizing violence and depravity (41). These civil unrest versions of the situation in New Orleans included numerous stories of widespread rape and murder, with children repeatedly

\footnotetext{
${ }^{55}$ Two images famously juxtaposed as reflective of the problematic portrayals of black Katrina survivors shows similar scenarios, where the subjects in each image wade through floodwaters carrying food. Both photos appeared in Yahoo News articles, but one referred to a black man as "looting" instead of "looking for food," which is how a similar photo of a young white couple was captioned (Mikkelson).
} 
rumored to be prime victims (none of which have been substantiated) (Carr) and were buoyed by government and private agencies, who failed to pursue firsthand accounts, and who maneuvered with swift action to get things "under control" in New Orleans by sending more military and private security forces to the city (Tierney and Bevc 41). Gradually, the media framework shifted from the civil unrest framework to a rhetoric of war, with the language and reactions to the situation remarkably similar to that of Iraq: "News accounts quoted officials as saying that "we are fighting a war on two fronts," the search and rescue missions bearing a marked resemblance to "search and destroy" urban missions in Iraq (41-2). A majority of the reporting of Hurricane Katrina was not only lacking in journalistic integrity, but it sensationalized stories that were blatantly false, and the ramifications of the media portrayal has had lasting effects on the people of the region.

The rhetoric of the "fresh start" has permeated discussions of New Orleans since 2005. This rhetoric implies that the "old" New Orleans perhaps needed to be washed away and that a fresh start will somehow redeem the city and make things right. As Klein aptly puts it: "Most people who survive a devastating disaster want the opposite of a clean slate: they want to salvage whatever they can and begin repairing what was not destroyed; they want to reaffirm their relatedness to the places that formed them" (8). Reflecting a common assumption that the New Orleanians who were too poor to leave during Katrina shouldn't miss their old poverty-stricken communities, Barbara Bush's callous comment that the horrifying conditions in the Astrodome and Superdome where the survivors were sent after the hurricane was likely better than their original homes shows the pervasiveness of the perception of the Katrina survivors as undeserving 
subjects who were somehow receiving special privileges from the disaster that they would not have otherwise gotten (Miller 131).

Tom Delay made a similarly obtuse remark to children living in a community of temporary housing in Texas, suggesting that the experience was a lot like camp and asking them, "isn't this kind of fun?" (131). Even Mayor Ray Nagin remarked more than once on the homeless population of New Orleans in the wake of Katrina, suggesting that this population were outsiders and that they should be sent away, when in fact, over $80 \%$ were New Orleanians and roughly 50\% were homeless due to the hurricane (Miller 127). The idea that there was some benefit freely handed out to all who claimed "victim" status from Katrina has added considerable weight to the psychological and social burden that the survivors endured, especially as they sought inclusion in the new communities to which they had been dispatched.

Alternately seen as victims or victimizers, the status of the survivors of Katrina was mediated through a rhetoric that situates opposing categories of "deserving/undeserving" as elemental to the operations of society, removing the position of the state and of media in the enactment of this construct. Reid highlights the perceptions of Katrina victims as atypical of the popular perception of victims of natural disasters, explaining that in the neoliberal "market governance" that defines the welfare and assistance operations of the United States, the citizenry are defined as "active agents" who are bequeathed with full autonomy by this liberal economic structure and who can exercise this agency in choosing how to engage with the market. This idea of choice constructs a distinction between those who have become "deviant" in the system (eg: those who are poor), and those who are the norm (eg: middle class), with the former 
being assigned this status because they presumably have made bad choices in an otherwise equal marketplace.

Reid explains the pervasiveness of this rhetoric and its influence in the public sphere. While the mainstream public generally sees someone who is in need due to "external" causes like a natural disaster as deserving of public assistance, those who are needy due to "personal" reasons are not deserving of such help. Obviously, structural inequalities are not typically considered relevant facets of this grossly inaccurate and oversimplified schema (745). For Katrina victims, the public perception of the black population who faced the worst consequences from the hurricane was complex, with a marked attitude toward the survivors as somehow undeserving of government aid (746). Reid highlights the "priming" of the public for this attitude in the media imagery and locates another major cause in the well-known stereotype of the black "welfare Queen" that persists in popular culture, and which was conjured in the imagery foregrounded from the disaster (745).

Like the war on terror, the state of emergency for Katrina survivors seems to have become permanent. The response of the government and complicity of the media in narrating a story of chaos and black rebellion created a diaspora of a significant population of domestic citizens. The survivors of Katrina were dispersed, while the city from where they were evicted is building itself anew, with the financial backing of the state. The modes of power operating inside and outside of New Orleans as the state seeks justification for getting rid of unwanted populations can be articulated through further inquiry into the biopolitical machine and its justifications for disposing of troublesome populations. The use of the law to declare emergency and institute permanent exceptional 
status is a way to control, disempower, segregate, and ultimately erase "surplus" populations:

The importance of this constitutive nexus between the state of exception and the concentration camp cannot be overestimated for a correct understanding of the nature of the camp. The 'protection' of freedom that is at issue in Schutzhaft is, ironically, protection against the suspension of law that characterizes the emergency. (Agamben, Means Without End 168-9 emphasis his)

In the deployment of the camps, for instance, the permanent state of emergency is accomplished by suspending civil liberties and constitutional rights under the guise of protection (for citizens' well-being or to protect civil liberties), when the only protection the government seeks is legal protection to justify the exclusion and erasure of its problematic populations. A less overt facet of Foucault's articulation of biopower is in what Agamben discusses further as "technologies of the self," where "processes of subjectivization bring the individual to bind himself to his own identity and consciousness and, at the same time, to an external power" (Homo Sacer 5). This shows up especially clearly in New Orleans, exemplified in the continuous focus of the city as a tourist destination, but also in the exile of the evacuees, who are forever marked by their status, labeled as either undeserving opportunistic welfare frauds, and/or as pitiable "victims" of Katrina.

While countless stories, both told and untold, comprise the experience of Katrina and the vulnerability of the poorer citizens in the face of the disaster, the status of "refugees" and "victims" that has been conferred on the survivors of the disaster 
contributes to the problem of the catastrophe for a population that has been blamed for its marginalization for generations. Even New Orleans Mayor Ray Nagin, in a 2006 reelection campaign speech, focused on what he called the "lack of love" in the black community during the hurricane, scolding the Katrina survivors for not "taking care" of each other and telling them that they needed to work harder to survive such struggles. He himself was criticized heavily for becoming all but invisible during the catastrophe, leaving the hurricane survivors and responders with little to no leadership on a local level, notwithstanding his grossly delayed order to evacuate and total neglect to create an efficient and timely evacuation route (McBride and Parker 357).

In the case of Katrina, a number of the major sources of actual relief for the survivors of the hurricane came not so much from the federal government as from international aid organizations like UNICEF or from non-profit, grassroots organizations, along with local community groups and churches (Eikenberry, Arroyave, and Cooper 160-164). Although numerous for-profit contractors were hired to provide relief for Katrina survivors and mobilized quickly to stake their claims, in actuality, it was a network of non-profit organizations and local volunteers who brought some of the most crucial relief to New Orleans. Not only were these NGOs (non-government actors) some of the major responders in the immediate aftermath of Katrina, but the international NGOs who responded-INGOs — assisted in New Orleans on an unprecedented level for a domestic disaster. Many of the international non-profit agencies that provided relief were, in fact, created to operate exclusively outside the U.S., assisting in countries that typically face the most destitute conditions on Earth, which could suggest that even 
within the borders of the U.S. the stranded black community in New Orleans was existing as a "third world."

Among the INGOs assisting victims were International Rescue Committee (whose work is primarily devoted to populations who are fleeing warzones or political persecution), Oxfam (which assists smaller nations who do not have adequate resources for their citizens), the American Refugee Committee, and UNICEF. These organizations, and several others who aided New Orleanians, had never before responded to a domestic disaster, and a few of them blatantly disregarded official policies that they would assist only in areas outside of the U.S. (Eikenberry, et al. 160-164).

Such an unprecedented response by so many INGOs - in addition to offers of aid from many small and developing countries around the world (Richard 2006) — is astounding considering the common perception that the United States is a world leader in helping other countries in times of crises. (Eikenberry, et al. 160)

Many of the INGOs who provided assistance in New Orleans did so because they could see quite plainly that the federal response was inadequate, while other INGOs were specifically asked to come to New Orleans by domestic agencies that were not receiving any assistance or direction from FEMA or from the Red Cross (164). In addition to the neglect of the government rescue effort, the need in New Orleans far exceeded monies donated by the administration and the public.

The distribution of funds for rebuilding efforts in New Orleans has failed to reach the majority of the population that needed it the most, and many families who left New Orleans cannot afford to return. This population encountered additional difficulties in 
finding acceptance in new communities, in no small part due to the negative images painted of the survivors in the days and weeks following Katrina (Miller 125-128). If survivors do make it back home, they quickly realize that the familiar city and spaces they knew as home may no longer be there. Shortly after the hurricane, for instance, the Bush administration funded an initiative to turn the New Orleans public school system into a charter school system, in which private schools - many of which operate as forprofit schools - would receive federal funds to educate the children of the city, who were given school vouchers to cover tuition at these institutions, effectively privatizing K-12 education in the city and erasing the public school system from existence (Klein 4-6). A 10-year report by the Brookings Institute on the recovery of New Orleans after Katrina notes that aside from the destruction of a significant portion of subsidized housing, which was quickly replaced by condos and mixed housing, the price for rent has drastically increased as wealthier demographics have begun to repopulate the city (Miller 126-7).

\section{Cornrow City vs. The French Quarter: Marie Laveau as Black Nemesis}

Perhaps coincidentally, the popular $F X$ television anthology American Horror Story had just debuted its third season, set in present day New Orleans and featuring Angela Basset as Marie Laveau, when the vandalism at Marie Laveau's tomb occurred. In October of 2013, AHS: Coven aired its first episode, just two months before the pink paint incident. The show has proved to be extremely popular since it first aired in 2011, with each season of the series introducing a new supernatural plot and setting, and recasting its recurring actors as new characters. Season three's Coven revolves around a group of fashionable witches who are evading witch-hunters and attempting to avoid public exposure by masquerading as students and teachers in a historic mansion disguised 
as a private boarding school in the French Quarter. The show introduces an immortal version of Marie Laveau as a Ninth Ward hairdresser and underground Voodoo Queen who lives in the back of her beauty shop, Cornrow City. Laveau figures as a fearsome nemesis for the coven, who are all descended from colonial-era Salem witches that managed to escape the infamous witch trials by resettling in New Orleans. One of the key subplots of the show is the territory war that Laveau wages against the coven. With the exception of Queenie (played by Gabourey Sidibe), said to be a descendant of real-life Salem slave, Tituba, the entire coven is white.

Thus disguised as an innocuous bourgeois sorority in the mystical New Orleans underbelly, the witches enjoy complete autonomy and enforce their own set of rules and punishments using supernatural powers to arm and protect themselves. New Orleans in this context constructed as a contested space of empowerment from the margins-a space that the fictionalized Laveau believes she should protect against white encroachment. Exercising control in a space where the line between surreal and real is often indistinguishable and magic can hide in plain sight, the coven simultaneously claims the margins of folk New Orleans to enact its power as it operates from a position of hegemonic white upper-class privilege. Throughout the season, and even in the closing scenes of the season finale, American Horror Story: Coven presents New Orleans as a space of competing historical claims, with racial tensions and sadistic racial violence featured as a fundamental aspect of an ongoing territory war between caricatured historical and fictional characters.

Though the show's protagonists are a coven of persecuted witches, the survival of who is presumably the key plot of the season, the show nonetheless returns to the 
predominant theme of racial violence as a subplot that overshadows the colorblind universalizing refrain of contested female power against patriarchal control. The most notable example of this racial foregrounding comes in the very first scene of the season. In addition to Marie Laveau, American Horror Story resurrects a second historical character from the chronicles of New Orleans antebellum society—a sadistic slaveowner named Delphine LaLaurie, based on a woman of the same name and portrayed by Kathy Bates. The opening scenes of season three feature LaLaurie in 1834, enjoying status as a high society socialite with three beautiful debutante daughters seeking suitors at a ball Delphine has hosted. Quickly, this image of propriety is shattered when she is informed that her daughter has been found with a slave named Bastien.

Ordering Bastien into her attic, the full, horrifying, scope of Delphine's character is revealed, as the camera pans slowly across the mutilated black bodies of moaning slaves, monstrously deformed into pitiful creatures who have been stripped of their identifying human characteristics — an eyeless man whose mouth has been sewn after being stuffed with feces, a woman whose face has been skinned and whose exposed facial muscles are harvesting maggots - before the shot lands on Bastien, gagged and chained from the ceiling, writhing as Madame LaLaurie places the severed head of a bull over Bastien's head. She and her husband step back and marvel at her "creation" of a real-life minotaur, and Delphine proudly recounts her education in Greek mythology as a formative influence for her inspiration to create this "half man, half beast," as the terrified eyes of Bastien peer out from behind the face of the bull.

By the time Voodoo Queen Marie Laveau is introduced as an enemy of the coven and the black avenger against Delphine, the magnificent natural powers of the group of 
witches—led by Jessica Lange as Fiona Goode, the coven's rebelliously complex and fierce "Supreme"- has already been established. Laveau's marginal status in the shadows of New Orleans is justified through her deployment as a historical foil to Delphine, with whom she has a personal feud. In murdering Bastien, Delphine had unknowingly killed Laveau's lover. Seeking revenge, Laveau retaliated by killing Delphine's family before casting a spell of immortality upon Madame LaLaurie and burying her alive in the backyard of her own mansion. The Voodoo Queen is not introduced to the current generation of the coven until she is provoked by Fiona, who, in retaliation for Laveau's refusal to sell her a spell for immortality, digs up the infamous Madame LaLaurie and forces her to become a servant in the coven's massive mansion. As the exotic spiritual suspect whose vengeful war on the coven is driven by her anachronistic figuring of the dehumanizing consequences of slavery, Marie Laveau becomes a symbol of militant black vengeance, an irrational Sapphire figure whose erasure from history is justified in the post-racial society that the coven foments.

The fictional resurrection of Laveau as a black villain against the white collective of witches projects her legacy onto an understanding of marginality and transgressive black embodiment that supports the neoliberal status quo, where a simplified and commoditized embrace of globalism and globalization as a social good gets deployed through token gestures of diversity that effectively remove the complexity and significance from historic and ongoing endeavors to bring about structural change for systemically marginalized communities. This is nowhere more evident than in the character development of Madame LaLaurie, whose frequent racist comments cast her as an unthreatening source of comic relief, in spite of the savage acts of terror she has 
committed on black men and women (and which, periodically, she continues to commit even in the present day). Regarding his use of LaLaurie, the show's creator, Ryan Murphy referred to the actual historical figure during an interview as "a pretty twisted sister" ("Ryan Murphy On"), adding that Kathy Bates' characterization of her as perhaps the funniest character on the show was an unexpected and welcome layer to the dynamic he had created for her:

[W]e thought, Oh, this character can be terrifying and funny at the same time. That was a discovery. I had thought Kathy's Delphine was going to be much, much, much darker. But because Kathy brings such an empathy to everything she does, and once we saw those first jokes, we thought, That's cool. And so we just started going that way with her dialogue, which is fun.

He explains that Bates' willingness to "make a beeline for any racist anthem" in the interest of humor was one of the refreshing aspects of her portrayal of LaLaurie ("Ryan Murphy Talks"). Simultaneously appropriating the legacies of both Voodoo Queen Marie Laveau and notorious slave torturer Delphine LaLaurie, Murphy's plot builds upon a fictionalized racial reckoning of slavery's legacy that the show implies is somehow resolved through retributive justice, illustrated in Laveau's merciless vendetta against Delphine.

The show ignores antebellum New Orleans' racially complex power structure altogether and highlights the bipartite racial divide of the Jim Crow era, utilizing the convenient racial rivalry between Laveau and Madame LaLaurie to frame its sociocultural milieu. The show injects its plot with racial tension by constructing present-day 
New Orleans as a homogenous space that has essentially transcended its historical traumas, such as a scene in episode one, when the witches take a tour of Delphine LaLaurie's mansion. The tour guide explains the history of antebellum New Orleans and claims that the code noir was for the protection of black New Orleanians against cruel slaveowners like LaLaurie, who employed her own "code of terror" that was far harsher than any legal code. The rewritten history of New Orleans in Coven not only casts Laveau as a threatening black parallel to LaLaurie's evil slave owner, but, as in Agamben's description of sovereign power's use of emergency to invoke exception for the "protection" of the citizenry, the juridical exception of the "code noir" that placed qualifiers on the ontological status of free blacks and restricted all blacks from exercising full agency, and which codified racial caste in antebellum New Orleans is cast yet again by Murphy as an exception. Redefining the black codes as rules that promised protection against whites, rather than as rules that enforced restrictions on black freedom, the "emergency" condition that justifies the codes in the fictional New Orleans history is the potential emergency of sadistic wayward white slave owners, who, presumably practice a "benevolent" form of slavery as a rule. This moment in the show, while very brief, nonetheless emphasizes an ideology that erases the material conditions of bare life as it existed for slaves simply by virtue of their enslavement, suggesting instead that the stratification of humanity via racial caste was separate from the institution of race-based slavery and, further, that this stratification existed as a regulating force against excessive abuses of power.

In spite of a colorblind façade that whitewashes the brutal history of slavery and creates a New Orleans utterly devoid of present-day inequities in some kind of post-racial 
alternate universe of potential, the show nonetheless parades disturbing racial traumas throughout the season as subplots and flashbacks. In renewing historic racial injustice as a fetishized spectacle of barbarism and revenge, Coven implies that the trauma of black oppression has been effectively dealt with through the supernatural underworld by the inversion of master-slave roles in an intimate sadomasochistic relationship between blacks and whites, where black torture is avenged in-kind. The show suggests that the vengeance embodied by Laveau, as a symbol of ethnocentric empowerment, brings about some sort of collective closure to the history of black oppression by white hegemony.

The opening scene of episode four emphasizes the theme of revenge and cathartic justice in black history. The scene depicts a 1960s era murder of a young black boy, who is chased down and lynched by three white men who are punishing him for attending an all-white school. Laveau's wrath is soon loosed upon the men for their crimes when she performs an exotic Voodoo ritual, resurrecting a small army of dead bodies that she commandeers as soldiers, who gruesomely attack the boy's killers. In one close-up shot, the rotting corpse of a Confederate soldier uses his musket to impale one of the racists, suggesting this irony as Laveau's last laugh against systemic racism (which, notably, is presented as an isolated occurrence enacted by aberrant elements of white society-three drunken men who Laveau executes as they celebrate their violence in a backwoods barn). The terrifying mob imagery evoked in the resurrection of zombie armies at the will of Laveau, which happens twice during the season, evokes the imagined hordes of murderous blacks that so haunted the white imagination (and perhaps still does), adding another significant layer to the Voodoo Queen's characterization as a threatening and 
ultimately "evil" representation of black power as vengeful antithesis to an otherwise innocuously post-racial society.

\section{The Queen is Dead, Long Live the Queen}

The racial embodiments characterized by Delphine LaLaurie and Marie Laveau, American Horror Story makes clear, are remnants of histories long gone. Delphine, having been buried since 1834 , has lost the familiar mores of her past life; society has moved past the racial hierarchy to which she is accustomed and from which she drew her sense of meaning and power as a wealthy white woman. Laveau, meanwhile, has changed her style and demeanor and continues to practice Voodoo and lead new generations of followers as the years pass, but she is presented as a merciless and bitter figure who refuses to let go of the pain of the past_-evident most clearly in the fact that she keeps her mutilated lover, Bastien, alive (presumably through a Voodoo resurrection spell). He has been magically transformed in this resurrection from a black man wearing the hollowed-out head of a bull into a real-life Minotaur, half man and half beast. Bastien is now Marie's minion, chained in a back room like an animal, let loose only to commit violence on her behalf - a literal manifestation of the abomination that Delphine had crudely created in the opening scene of the season, and a symbol of the bestial violence to which Laveau, like Delphine has committed herself.

The two women are characterized as equally evil. At points in the season, both Laveau and Delphine engage in dismemberment of the other and both use a perverse "beauty treatment" that entails slathering human blood all over themselves. We also discover that both have committed infanticide. The primitive racial attitude that connects the two women in an evil sadomasochistic double bind produces inevitable consequences 
when the season concludes by revealing that both have died and gone to Hell by inadvertently breaking the Voodoo magic that had kept them alive for so long. Coven's Hell is the never-ending repetition of the worst world one can imagine. For both women, it results in Laveau being forced to torture Delphine's innocent daughter as Delphine watches helplessly, for all eternity.

Laveau's imagined afterlife as an enslaver and torturer is justified by the characterization of the Voodoo Queen as, essentially, a black version of Madame LaLaurie - whose real-life history, in fact, reveals that she was very likely an actual slave torturer, investigated by New Orleans authorities under suspicions of slave abuse more than once before a fire in her home in April of 1834 brought officials to the residence and her secret sadism was confirmed. When New Orleanians discovered what Delphine LaLaurie had done to her slaves, an angry mob ran the family out of town (Darkis 390-4), though the show does not portray this facet of Madame LaLaurie's exile from New Orleans by its residents. Instead of portraying LaLaurie's shame and exile at the hands of antebellum New Orleans society, Murphy instead rewrites Delphine's punishment as a personal attack from Marie Laveau. The show homogenizes New Orleans as a fixed, sanctified space where structural violence against populations of color is erased from the story of slavery, and where even the devastating effects of 2005's Hurricane Katrina on the city and its communities of color are essentially invisible.

Coven acts as a cultural-historical authority to duplicate the same types of dismissive imaginary dynamics between Laveau, as a figure of black empowerment, and the white society she threatens, just as agents of white hegemony have done with Laveau's legacy since her own lifetime. The set-up of competing claims to the historical 
legacy of persecution and power from the margins negates the lasting impact that white hegemony has had for communities of color in the United States overall. Setting the show in post-Katrina New Orleans situates the plot within a space fraught with political, historic, and social tension, and which has been examined since the hurricane as a reflection of ongoing racial injustice that pervades the nation at large. Yet, in American Horror Story, post-Katrina New Orleans is an overdetermined space where marginalization and power have nothing to do with race. Aside from the rare offhand reference to the hurricane, there is no indication that the catastrophe ever happened. In effect, the show wipes all traces of Hurricane Katrina off the map of New Orleans spacetime.

Coven presents a nebulously post-racial idea of difference that frames white supremacy as an outdated relic of a milieu that no longer needs to be considered in the larger context of power and race. Rather, the concern in the fictional New Orleans is a threat to the feminine transgressive power from patriarchal male privilege in Delphi's ancient mission to hunt down and exterminate all witches. Once this epic beast is felled, the coven can deal with its other, perhaps even more important concern: the question of who will reign supreme upon the death of Fiona. This new society of New Orleans is a world that has transcended the barbaric retributive justice of the New Orleans underworld. As the show ends, we are granted a glimpse of the new face of justice and hope in the visage of the Supreme, none other than Fiona's daughter, Cordelia, whose royal bloodline fated her rise as divine right of supernatural authority. As the new Supreme and the ultimate authority over the coven, Cordelia uses the media to draw attention to their existence and bring them out of the margins and into the limelight, 
where they can serve humanity and share their gifts freely. In a televised interview, Cordelia explains that they have lived in the shadows too long, and she extends an open invitation for witches who might be watching the interview to come to New Orleans and join their order. The season ends as a massive collection of young, overwhelmingly white women eagerly wait outside the gates of the mansion for their chance to join the order.

The mythology constructed in Coven utilizes the history of New Orleans to lend authenticity to the notion that its white female protagonists live in a threatening society due to their exceptional gifts, and that only in a city that embraces exception can they find refuge. Once they find this refuge and empower themselves inside this transgressive space, the coven asserts its presence as the ruling power of the margins while simultaneously dissolving the space of the margin by opening it for others of their kind to stake a claim. Having won total control, the group declares itself as the new reigning authority and publicly opens of the margin of New Orleans to a new chapter in American history. The violent history of the space is now wiped clean in the annihilation of Laveau and her followers, as well as the defeat of the patriarchal quasi nemesis, Delphi, whose presence accounts for considerably less screen time and bloodshed than does Laveau. As an idealized space of marginal existence, New Orleans' complex history and its transgressive historical legacy is mined and commoditized by the producers in order to add an air of cultural depth that justifies the staging of a race war between white and black women, which is eventually (and effortlessly) won by the whites, whose colorblind universal superiority nonetheless allows them to erase the black Voodoo community from its landscape altogether. 


\section{The Big Easy and The New Norm}

When the President of the United States declares a state of emergency and civil liberties are sacrificed in the name of state protection of vulnerable bodies, space is thereby opened for corporations (or any other number of actors) to institute themselves as the new order - in effect, reformulated sovereign powers that have managed to effectively transcend national affiliation and legal accountability or governmental regulation - so that when the emergency has ended, original conditions have been substituted for the exception, and the exceptional condition has now become the rule, the new sovereign state. In New Orleans, the state of emergency has become the norm: a campaign of reconstruction working as the city's newest stock in trade; the disaster tourism industry situated as a semi-permanent source of revenue; and the emergency evacuation turning into permanent exile for significant numbers of black survivors of the hurricane. The city has become a perpetual emergency.

Communities of social and familial networks, along with financial, emotional, and spiritual support systems were broken by the response to Katrina, with evacuees sentoften with no choice - to locations in all 50 states (Miller 130), effectively constituting an exile. Walter Benjamin, in discussing the rise of Fascism and the state of emergency from which Agamben's discussion draws its premise argues that the normalizing of totalitarian techniques via the declaration of emergency requires an urgent response, "a real state of emergency," that will undermine the state's ability to appropriate the emergency for its own end. "One reason why Fascism has a chance," Benjamin states, "is that in the name of progress its opponents treat it as a historical norm" (“Theses” 257). Totalitarianism and democracy become indistinguishable in their practice as the neoliberal agenda is 
forced — sometimes violently—upon populations, couched as public good or for protective purposes, but in reality serving and protecting only the interests of a miniscule percentage of the citizenry. ${ }^{56}$

For a nation whose exceptionalism is supported through the rhetoric of revolution, the opposition to tyranny, and the privileging of individual liberty, the revelations of Katrina open a space of inquiry that highlights the deepest and oldest cracks in the foundation of American empire from within the borders of the United States, even as the nation-state has begun to occupy a position of power that transcends territorial boundaries. An analysis of the traumatizing response of the federal government toward the Katrina survivors exposes some deep-seated anxieties that are inherent in the nation whose Constitution has been plagued by hypocrisy—especially as regards human rights - since birth. In the homogenization of the city of New Orleans, especially after Katrina, the hierarchy of power is unknowable, as corporations and contracts control a significant number of markets in the city.

Exploring the power structures as they have existed in New Orleans historically, and they exist today, and investigating the role of the nation-state in the emergency that has been ongoing in New Orleans since 2005, we can gain insight not just into the position of margins as contested spaces of transgressive power, but we can also see how the biopolitical state's adoption of neoliberalism in the last 40 years requires a flexible approach to developing an understanding of the political machinery that operates in the U.S. Gaining such an understanding of the past and present mechanics of this system by analyzing varied examples of its effects in politics, society, and cultural productions

\footnotetext{
56 Or none, in the case of transnational corporations whose allegiance is to the corporation as a fictive
} "person" whose ontological status typically guarantees protections but not punishments of citizenship 
allows us to begin to formulate a working mode of theorization for considering how this system is potentially affecting the social dynamics and lives of American citizens everywhere on an ongoing basis and how new sites of agency and possibility might be imagined. 


\title{
CONCLUSION
}

\section{TIME, SPACE, AND NOT-SO-FINAL FRONTIERS}

\begin{abstract}
"And this spectral form of civilization which the Americans have invented, an ephemeral form so close to vanishing point, suddenly seems the best adapted to the probabilitythe probability only - of the life that lies in store for us. The form that dominates the American West, and doubtless all of American culture, is a seismic form: a fractal, interstitial culture, born of a rift with the Old World, a tactile, fragile, mobile, superficial culture-you have to follow its own rules to grasp how it works: seismic shifting, soft technologies." (Baudrillard, America 10-11)
\end{abstract}

As American capitalism has embedded neoliberal mechanisms of control into its biopolitical machinery, the self-destructive cycle of desire, disappointment, and disillusion that characterizes ideological constructions of democracy and civilization has generated communal relations around increasingly unconvincing renditions of harmony and stability. Anthropologist David Graeber notes that capitalism is frequently conflated with democracy in popular rhetoric - a cause and symptom of a larger societal shift in early modern European civilizations that privatizes and privileges property as a fundamental element of civilized society, notably manifesting in the enclosure movements of the sixteenth and seventeenth centuries. The notion of private property protected by its private status "against all the world" seems to parallel what he calls the emergence of "relations of avoidance" that dictated that the higher up in social status, the more private and separated, protected "against all the world" one must regard a superior. The gradual indoctrination of manners 
and deference into English society bore marked resemblance to the deference with whichone was eventually expected to treat the private property of others (35-7). As "imagined communities" of America arose around notions of the sacredness of shared national affiliation and the privilege of participation in such a society, the weight of citizenship, accordingly, has been loaded down with changing expectations for biopolitical discipline/self-discipline. Societal role-playing, and docile submission within a capitalist matrix have become preconditions for inclusion in democratic stability (a stability necessarily weakened by its reliance on market exchange values).

I have explored representations of disaster and recovery in their contemporary contexts as well as through cultural and historical re-imaginings in the present day to better understand the social consequences and manifestations of citizenship in a biopolitical society. Tracing some of the common socio-political themes across these disasters, this study generates insight into the impact of neoliberalism's development as it has become entrenched in modern society, nationally and globally. Concluding each of the three main chapters with discussions of postmodern renderings of the historical subjects I explored, I have framed my interpretation of these productions via the same inquiries with which I framed this project as a whole. The constellations of these historical and cultural phenomena create connections across and between time and space to create meaningful discourses about democracy as it gets shaped and reshaped in the experience of citizenship as it is lived.

What I show in the explication of Jackie is an ongoing public politics that mediates the practices of American democracy, as democratic citizenry gets lost in the consumption of imaginary civilizations that propagate at will. In Chapter Two's analysis 
of Interstellar, the imperial "progress" that hinges on a notion of civilization as advancing along a clear and righteous path projects the consequences of this ideology back from the imagined future, onto our present-day apocalyptic concerns, generating new questions about America's "destiny" as a global imperial power. The sublimation of present-minded cautionary logic into rhetorics of destiny invites us to think about how history and disaster converse with one another through historical and popular cultural stagings of catastrophe. Such dynamics as they are illustrated in these two films injects the landscape of Chapter Three's post-Katrina New Orleans with an urgency that reflects the consequences of abstracting and restaging isolated elements of the past as a more harmonic version of the original. The whitewashed American aesthetic that encloses transgressive black authority into commoditized spaces of hegemonic control nonetheless depends on the continuation of precarious economic, ecological, and social constructions that, embedded as they are in neoliberal capitalism, cannot plausibly be maintained as a representative democracy indefinitely.

The historical treatment of Mary Lincoln has grown more nuanced over the years, but the continued and largely redundant focus on her inappropriate behavior, in lieu of an extended inquiry into the behavior of other social actors, has tended to be a major framing device for analyzing her role as a First Lady and widow. ${ }^{57}$ As in Larraín's reverential recapitulation of Jackie Kennedy as an American goddess-queen imbued with the powers of creation, the entrenched socio-historical version of Lincoln as a representative figure - like Jackie's mannequins — seems to find new modes of

\footnotetext{
${ }^{57}$ When "The Insanity Files" from her trial became available to the public in the 1980s, new details finally emerged that may well have been responsible for more nuanced approaches to Lincoln's legacy in the current historical scholarship. Neely and McMurtry were given access and compiled them into book form, which I reference in Chapter One's discussion of her trial.
} 
reproducing the same image. Similarly, the freewheeling pastiche of pop culture shorthand for black empowerment, plopped on the blank canvas of imaginary New Orleans in Ryan Murphy's American Horror Story serves up a familiar story of Laveau as an exotic and troubling remnant of inferior primitive histories, answering an unasked question about the ownership of history and culture in New Orleans-a question of "deservingness," that justifies the rightful bequeathal of the city to the proper ruling order - through a narrative we've seen in the city and throughout the U.S. and will likely see again.

The scope and approach of this project has been driven a desire to understand distinctions that constitute the difference between disaster and harmony, chaos and order, sanity and insanity. Ultimately, these categories expose themselves as fragile constructions that depend upon the general acceptance and acquiescence from society. Experiences of catastrophic phenomena, however, deteriorate the trappings of a prosperous and orderly civilization, requiring the citizenry to adopt a revamped perspective about how a democracy should proceed. Geographer Harvey Molotch finds particular potential in disasters because in addition to "offering a tracer to the past," he writes, we can also understand the present moment "of Time Zero," when the underlying conditions of power upon which society's order depended have been unveiled (371). At its core, this research raises crucial questions about the role of American citizenship in the United States and the mediation of that position as it figures in political representatives and historical revisions.

Rather than altering fundamental realities of democracy, as if struggle and conflict should not enter the realm of a democratic civilization, Dana Nelson proposes the U.S. 
could move past its hang ups and aversions to discomfort and uncertainty, and instead work towards a more genuinely rational acceptance of discord as a healthy component of democracy in its "ugly" realness. "Ugly democracy" is a citizenship that "affirms not wholeness and symbolic consensus but the inevitable incompleteness of always dissensual community [...] [T]his alternative political aesthetic," unlike the transcendent universalizing aesthetics of Camelot, “The Frontier in American History,” Disney New Orleans, or the Old South, is "situated within the context of human particularity and the open-endedness of regular human interaction, offer[ing] an important alternative representation for radical democratic praxis" (220). Engaging in these conversations with attention to the state of emergency in American society illuminates critical questions about the linkages between citizenship and democracy in a postnational global economy.

Disaster Studies scholar Kathleen Tierney emphasizes the need for more attention to the field, as the state of emergency and the catastrophic events of modernity have begun to encroach upon the day-to-day status quo with increasing intensity and frequency:

$[\mathrm{M}]$ any disaster scholars now argue that, far from being nonroutine, disasters should be understood as normal, common occurrences that reflect the characteristics of the societies in which they occur, characteristics that include industrialization, urbanization, globalization, legacies of colonialism, political economic forces, and mechanisms of control exercised over both the environment and civil society. ("From the Margins" 518) 
Concerns about the future as it is being affected by the present moment could easily offer a number of paths into disaster as a site of study. In particular, the connections that arise between the Dust Bowl and Hurricane Katrina generate numerous sites of interrogation, as the magnitude of both disasters ultimately hinged upon a lack of government oversight into the risks of both areas-largely in the interest of profit margins and political power-at the expense of countless American lives, creating two of the largest emergency migrations in domestic history. That one group of "refugees" was predominantly poor and white and the other was predominantly poor and black, and that both were subjected to enormous discrimination even as they languished from devastating environmental conditions provides insight about the debilitating patterns of capitalism as it exists in the United States.

The apocalyptic imagery of all three of these disasters is striking, and the language and imagery of Biblical apocalypse - while obviously well-researched across many fields and for many years - still frames disasters in ways that generate productive conversations about imagined communities, as Woody Guthrie's Dust Bowl songs, for instance, would attest. The space of apocalypse can be freeing in this sense. As Naomi Klein has modeled in her study of neoliberal control, catastrophe as a spatio-temporal rupture in society and history is a spacetime of potential. Understanding these phenomena in new ways, we can locate alternate understandings about how to inhabit catastrophic chaos and its aftermath materially, as democratic citizens.

The ruins and ghost towns left behind in the Dust Bowl Plains and in the postKatrina Gulf raise important questions about America's conflation of citizenship with capitalism — questions, for instance, that have immediate value for research on the early 
2000s housing market "bubble" and subsequent economic markets currently growing at a rapid rate that may be heading in similar directions (such as post-secondary education). Researching disaster with a focus on these concerns, in particular, can provide insight into ideologies of civilization as they continue to manifest through mediated representatives and surrogates. ${ }^{58}$

Using disaster to interrogate the role of power in democratic governmentality that values its own protection as the highest biopolitical good also invites us to deeply consider how space functions in community formation beyond the "imagined" shared community of national citizenship, without necessarily constructing ideological "state vs. federal" binaries about juridical authority. Considering the possibilities and limitations for individual agency under a biopolitical regime that relies upon subjective selfgovernance (at least in part), alters the space of catastrophe and suggests more flexible ways of thinking about chaos and "ugly democracy" as practices that can exist both inside and outside of democratic ideology, where social death does not have to be negatively correlated with passivity and acquiescence, and where we can imagine a community with a desire framed by an "uglier" and more creative imagining of democracy - a democracy generated, perhaps, from the material conditions on the ground, in the spaces of current and ongoing emergencies. ${ }^{59}$

\footnotetext{
${ }^{58}$ For instance, the ubiquitous "house flipper" celebrities have continued to dominate on channels like HGTV. The stars of such shows are often married couples, promoting similar themes as we saw in New Orleans, where "ruins" are resurrected in the name of capitalist enterprise, glamourized as the kind of claim-staking that has defined American land use and "progress" since before Daniel Boone figured it so popularly, promoting real estate as a market of disposability. The familiarity of viewers with the show's stars engenders an idealized "American Dream" that conflates stability (in the marriage and "good life" to come) with risk (in the housing market) via the quick turnaround of property.

${ }^{59}$ Historian Jacob Remes usefully interrogates the distinction between ideological biopolitical democracy and the material conditions of citizenship and community as a practice in times of disaster in his 2016 book, Disaster Citizenship.
} 


\section{REFERENCES}

Adams, Vincanne, Taslim Van Hattum, and Diana English. "Chronic Disaster Syndrome: Displacement, Disaster Capitalism, and the Eviction of the Poor from New Orleans.” American Ethnologist, vol. 36, no. 4, 2009, 615-636. JSTOR. Accessed 01 Dec. 2014.

Agamben, Giorgio. Homo Sacer. New York: Zone, 2002. Print.

---. Means Without End: Notes on Politics. Minneapolis: University of Minnesota Press, 2000. Print.

---. The Coming Community. Minneapolis: University of Minnesota Press, 1993. Print.

Anderson, Benedict R. O'G. Imagined Communities: Reflections on the Origin and Spread of Nationalism. London: Verso, 2006. Print.

Anthony, Carl Sferrazza. First Ladies: The Saga of the Presidents' Wives and Their Power, 1789-1961. New York: Quill/William Morrow, 1990. Print.

Attie, Jeanie. Patriotic Toil: Northern Women and the American Civil War. Ithaca, N.Y.: Cornell University Press, 1998. Print.

Bach, Jennifer L. "Acts of Remembrance: Mary Todd Lincoln and Her Husband's Memory." Journal of the Abraham Lincoln Association, vol. 25, no.2, 2004, 2549. JSTOR. Accessed 01 Dec. 2012.

Baker, Jean H. Mary Todd Lincoln: A Biography. New York: W.W. Norton, 2008. Print. 
Battle, Laura Elizabeth Lee. Forget-me-nots of the Civil War: A Romance, Containing Reminiscenes and Original Letters of Two Confederate Soldiers. St. Louis, MO: Press A.R. Fleming Print. 1909. Print.

Baudrillard, Jean. America. London: Verso, 1989. Print.

--- . Simulacra and Simulation. Ann Arbor: U of Michigan, 2014. Print.

Bender, Thomas. "The 'Rural' Cemetery Movement: Urban Travail and the Appeal of Nature." New England Quarterly: A Historical Review of New England Life and Letters vol. 47, no. 2, 1974, 196-211. ProQuest. Accessed 03 May 2013.

Benjamin, Walter, Hannah Arendt, and Harry. Zohn. Illuminations. 1st Schocken paperback ed. New York: Schocken Books, 1969. Print.

---. "Capitalism as Religion." M. Bullock and M.W. Jennings (eds) Selected Writings, vol. 1, 1913-1926. Cambridge, MA: Harvard University Press

Bennett, H.H. Chief Soil Conservation Service, US Department of Agriculture. "Land Abuse is Cause of Floods and Dust." New York Times (1923-Current file). Mar 29 1936. ProQuest. Accessed 22 May 2014.

Berlant, Lauren. "Cruel Optimism." Differences 17.3 (2006): 20-36. Print.

---. "Uncle Sam Needs a Wife: Citizenship and Denegation." Materializing Democracy: Toward a Revitalized Cultural Politics. Ed. Dana D. Nelson and Russ Castronovo. Durham: Duke UP, 2002. 144-74. Print.

Berlin, Ira. Slaves without Masters: The Free Negro in the Antebellum South. New York: New, 2007. Print.

Bierce, Ambrose. A Sole Survivor: Bits of Autobiography. ed. S.T. Joshi and David E. Schultz. Knoxville: U of Tennessee, 1998. Print. 
Blencowe, Claire. "Foucault's and Arendt's 'insider View' of Biopolitics: A Critique of Agamben." History of the Human Sciences, vol 23, no. 5, 2010, pp. 113-130. ProQuest. Accessed 18 March 2017.

Blum, John Morton. The Republican Roosevelt. Cambridge, Mass.: Harvard University Press, 1977. Print.

"Brady's Photographs; Pictures of the Dead at Antietam." The New York Times. The New York Times, 20 Oct. 1862. Accessed 01 Apr. 2015.

Brophy, Alfred L. "'These Great and Beautiful Republics of the Dead': Public Constitutionalism and the Antebellum Cemetery." Social Science Research Network Working Paper Series, August 2013. JSTOR. Accessed 07 May 2015.

Brown, Wendy. Regulating Aversion: Tolerance in the Age of Identity and Empire. Princeton, N.J.: Princeton University Press, 2006. Print.

Burns, Ken, Dayton Duncan, Julie Dunfey, Craig Mellish, Ryan Gifford, Buddy Squires, Stephen McCarthy, Peter Coyote, Carolyn McCormick, Patricia Clarkson, Amy Madigan, and Kevin Conway. The Dust Bowl: A Film by Ken Burns. Arlington, Va.: PBS Distribution, 2012. DVD.

Burns, Lisa M. First Ladies and the Fourth Estate: Press Framing of Presidential Wives. DeKalb: Northern Illinois University Press, 2008. Print.

Butler, Brooke. The Other Magic Kingdom: New Orleans Voodoo and Tourism. Diss. U of California, Davis, 2011. WorldCat [OCLC], Accessed 10 Dec. 2015.

Carr, David. "More Horrible Than Truth: News Reports." The New York Times. The New York Times, 19 Sept. 2005, Accessed 18 Feb. 2015. 
Cashin, Joan E. First Lady of the Confederacy: Varina Davis's Civil War. Boston: Belknap of Harvard UP, 2006. Print.

Castleman, Alfred Lewis. "Diary of Alfred Lewis Castleman, September, 1862.” The Army of the Potomac, Behind the Scenes: a Diary of Unwritten History: from the Organization of the Army ... to the Close of the Campaign in Virginia, About the First Day of January, 63. Strickland: Milwaukee, 1863. pp. 288.

Castronovo, Russ. Necro Citizenship: Death, Eroticism, and the Public Sphere in the Nineteenth-century United States. Durham: London, 2001. Print.

Chesnut, Mary Boykin, and Ben Ames Williams. A Diary from Dixie. Boston: Houghton Mifflin Co., 1949. Print.

Cheung, Floyd D. "'Les Cenelles" and Quadroon Balls: "Hidden Transcripts" of Resistance and Domination in New Orleans, 1803-1845." The Southern Literary Journal vol. 29, no. 2, 1997, pp. 5-16. JSTOR, Accessed 2 Apr. 2015.

"The Civil War By the Numbers." PBS. PBS. Accessed 10 June 2015.

Corliss, Richard. "Review: the Wonder of Worlds Beyond." Time, vol. 184, no. 18, 2014. Print.

Cronon, William. "Revisiting the Vanishing Frontier: The Legacy of Frederick Jackson Turner." The Western Historical Quarterly, vol. 18, no. 2, 1987, pp. 157176. ProQuest. Accessed 03 March 2015.

Currie, Candace. "Eternally Green: Mount Auburn Founded on 'Natural Burials.'" Mount Auburn. Mount Auburn Cemetery, vol. 27 Nov. 2013, Accessed 09 Feb. 2016. 
Curtis, Rowland. "Katrina and the Waves: Bad Organization, Natural Evil or the State." Culture and Organization, vol. 14, no. 2, 2008, pp. 113-33, Academic Search Complete [EBSCO]. Accessed 2 June 2015.

Curtis, William E. "Voodoo Rites Practiced in New Orleans." The Evening Star [Washington, D.C.] 22 Mar. 1909: 8. Chronicling America: Historic American Newspapers. Accessed 03 Feb. 2015.

McCormack, David. "New Orleans' Oldest Cemetery Bans Solo Tourists after Repeated Vandalism of Above-ground Crypt of 19th Century Voodoo Priestess Marie Laveau." Daily Mail Online. Associated Newspapers, 27 Jan. 2015. Accessed 04 Jan. 2016.

Dalton, Kathleen. Theodore Roosevelt: A Strenuous Life. New York: Alfred A. K, 2002. Print.

Danger, Tatiana. "Mistress Marie Laveau: The Real Story of the Voodoo Queen of New Orleans." Roadtrippers. Roadtrippers, Inc., 27 Oct. 1970. Accessed 22 Dec. 2015. “Daniel Boone.” New-Bedford Mercury. 11 April 1834. America's Historical Newspapers. Accessed 24 May 2013.

Darkis, Fred Jr. "Madame Lalaurie of New Orleans." Louisiana History: The Journal of the Louisiana Historical Association, vol. 23, no. 4, 1982, pp. 383-399. EBSCO, Accessed 17 March 2016.

Davis, David Brion. Inhuman Bondage: The Rise and Fall of Slavery in the New World. Oxford: Oxford UP, 2008. Print. 
Davis, Varina, and Mattie S. Meadows. Survey Report, An Old Letter: 1937 Aug. 25, Research Made by Mattie S. Meadows. Richmond: Virginia Historical Inventory: Library of Virginia, 1998. TIFF.

"The Dead Voudou Queen; Marie Laveau's Place in the History of New-Orleans." The New York Times. The New York Times, 23 June 1881. Accessed 30 March 2017. Death Notice, Daniel Boone. Rhode-Island American. 10 Nov. 1820. America's Historical Newspapers. Accessed 26 May 2013.

"Death of Marie Laveau." Omaha Daily Bee, 22 June 1881, pp. 6-6. EBSCO, Accessed 3 May 2015.

Deverell, William F. A Companion to the American West. Malden, MA: Blackwell, 2004. Print.

Diamond, Jared M. Guns, Germs, and Steel: The Fates of Human Societies. New York: Norton, 2005. Print

Dingwerth, Klaus. "Private Transnational Governance and the Developing World: A Comparative Perspective." International Studies Quarterly, vol. 52, no. 3, 2008, pp. 607-634. JSTOR, Accessed 07 December 2015.

Edwards, Rebecca. New Spirits: Americans in the Gilded Age, 1865-1905. New York: Oxford University Press, 2006. Print.

Eikenberry, Angela M., Verónica Arroyave, and Tracy Cooper. "Administrative Failure and the International NGO Response to Hurricane Katrina." Public Administration Review vol. 67, 2007, pp. 160-170. ProQuest, Accessed 03 July 2015. 
Eisenstein, Zillah R. The Audacity of Races and Genders: A Personal and Global Story of the Obama Election. London: Zed, 2009. Print.

Elias, Norbert. On Civilization, Power and Knowledge: Selected Writings. Ed. Stephen Mennell and John Goudsblom. Chicago: U of Chicago, 1998. Print.

Emerson, Jason. The Madness of Mary Lincoln. Carbondale: Southern Illinois University Press, 2007. Print.

Erikson, Kai. Everything in Its Path: Destruction of Community in the Buffalo Creek Flood. New York: Simon and Schuster, 2006. Print.

--- . "Studying Katrina" Sociological Inquiry vol. 84, no. 3, 2014, pp. 344-353. JSTOR, Accessed 02 January 2017.

"Executive Office of the President." National Archives and Records Administration. National Archives and Records Administration. Accessed 3 Jan. 2017.

Faragher, John Mack. Introduction. Rereading Frederick Jackson Turner: "The Significance of the Frontier in American History" and Other Essays, by Frederick Jackson Turner. New Haven, Conn.: Yale University Press, 1998.

Faust, Drew Gilpin. This Republic of Suffering: Death and the American Civil War. New York: Alfred A. K, 2008. Print.

Formo, Brian. "Director Pablo Larrain on His Additions to the 'Jackie' Narrative and Why He Left 'Scarface'." Collider. Complex Media, Inc., 07 Dec. 2016. Accessed 10 Mar. 2017.

Foucault, Michel. Madness and Civilization : A History of Insanity in the Age of Reason. New York: Vintage Books, 1988. Print. 
---. "Of Other Spaces, Heterotopias." Michel Foucault, Info. Foucault.info. 2012. Accessed 9 May 2013.

---. et al. Society Must Be Defended: Lectures at the Collège De France, 1975-76. New York: Picador, 2003. Print.

---. The History of Sexuality. Harmondsworth: Penguin, 1992. Print.

French, Stanley. "The Cemetery as Cultural Institution: The Establishment of Mount Auburn and the 'Rural Cemetery' Movement.” American Quarterly vol. 2, no. 1, March 1974, pp. 37-59. JSTOR. Accessed 11 December 2011.

Frey, John Carlos. "Can the Lower Ninth Ward Ever Recover from Katrina?" PBS. Public Broadcasting Service, Dec. 2013. Accessed 11 May 2015.

Garland, Hamlin. "Hitting the Trail." McClure's Magazine, vol. 12, no. 4. Feb. 1899. Accessed 12 December 2016.

"General Review Of the World's Happenings for a Week, in Brief. Foreign and Domestic Pointers." Southern Argus [Baxter Springs, Kansas] 26 Nov. 1891, News/Opinion sec. 2. America's Historical Newspapers. Accessed 19 Apr. 2016.

Gilbert, Sandra M. Death's Door: Modern Dying and the Ways We Grieve. New York: W.W. Norton, 2006. Print.

Giroux, Henry A. "Reading Hurricane Katrina: Race, Class, and the Biopolitics of Disposability." College Literature vol. 33, no. 3 , 2006, pp. 171-196. ProQuest, Accessed 10 March 2017.

Graeber, David. Possibilities: Essays on Hierarchy, Rebellion, and Desire. Oakland, CA: AK Press, 2007. Print. 
Grant, Susan-Mary. "Raising the Dead: War, Memory and American National Identity." Nations and Nationalism, vol. 11, no. 4, 2005, pp. 509-529. JSTOR, Accessed 10 May 2015.

Gregory, James N. American Exodus: The Dust Bowl Migration and Okie Culture in California. New York: Oxford University Press, 1989. Print.

Grove, Kevin. "Biopolitics and Adaptation: Governing Socio-Ecological Contingency through Climate Change and Disaster Studies." Geography Compass vol. 8, no. 3, 2014, pp. 198-210. EBSCO, Accessed 01 April 2017.

Guelzo, Allen C. Fateful Lightning: A New History of the Civil War \& Reconstruction. Oxford UP, 2012. Print.

Hacker, David J. "A Census-Based Count of the Civil War Dead." Civil War History 57.4, 2011. JSTOR. Accessed Jan 132015.

Halttunen, Karen. Confidence Men and Painted Women: A Study of Middle-Class Culture in America, 1830-1870. New Haven: Yale University Press, 1982. Print.

Harvey, David. "Between Space and Time: Reflections on the Geographical Imagination." Annals of the Association of American Geographers vol. 80, no. 3, 1990, pp. 418-434. JSTOR. Accessed 03 April 2013.

---. The Condition of Postmodernity: An Enquiry into the Origins of Cultural Change. Oxford: Blackwell, 1989. Print

Hayoun, Massoud. "Black Is Beautiful at 'Voodoo Queen' Marie Laveau's New Shrine." Al Jazeera America. Al Jazeera Media Network, 10 Mar. 2015. Accessed 14 Mar. 2016. 
Hendricks, Nancy. America's First Ladies: A Historical Encyclopedia and Primary Document Collection of the Remarkable Women of the White House. Santa Barbara, CA: ABC-CLIO, 2015. Print.

Herman, Daniel J. "The Other Daniel Boone: The Nascence of a Middle-Class Hunter Hero, 1784-1860." Journal of Early Republic vol. 18, no. 3, 1998, pp. 429-457. EBSCO. Accessed 19 June 2012.

@ HillaryClinton. "Hillary Clinton Verified Twitter Account." Twitter. Twitter, 09 Nov. 2016. Accessed 19 Mar. 2017.

Hoelscher, Steven. "Making Place, Making Race: Performances of Whiteness in the Jim Crow South." Annals of the Association of American Geographers vol. 93, no. 3, 2003, pp. 657-686. ProQuest. 09 November 2016.

Hofstadter, Richard. The Paranoid Style in American Politics: And Other Essays. New York: Vintage, 1965. Print.

Homans, Margaret. Royal Representations: Queen Victoria and British Culture, 18371876. Chicago: U of Chicago, 1998. Print.

Horwitz, Tony. Confederates in the Attic: Dispatches from the Unfinished Civil War. New York: Pantheon, 1998. Print.

Hughes, Jonathan. "The Great Land Ordinances." Essays on the Economy of the Old Northwest, Eds. David Klingaman and Richard Vedder. Athens: Ohio University Press, 1987. pp. 1-24. Print.

Hurt, R. Douglas. The Dust Bowl: An Agricultural and Social History. Chicago: NelsonHall, 1984. Print. 
Jackie. Dir. Pablo Larraín. By Noah Oppenheim. Perf. Natalie Portman. Fox Searchlight, 2016. Film.

Jacobson, David. Place and Belonging in America. Johns Hopkins UP, 2002. Print.

Juergens, George. Joseph Pulitzer and the New York World. Princeton: Princeton UP, 1966. Print.

Keckley, Elizabeth. Behind the Scenes: Or, Thirty Years a Slave and Four Years in the White House. New York: Oxford University Press, 1988. Print.

Klein, Naomi. The Shock Doctrine: The Rise of Disaster Capitalism. London: Penguin, 2008. Print.

Kloppenberg, James T. Uncertain Victory: Social Democracy and Progressivism in European and American Thought, 1870-1920. New York: Oxford University Press, 1986. Print.

Laskin, Lisa. "'No Nearer Heaven Now but Rather Farther Off": The Religious Compromises and Conflicts of Northern Soldiers." The View from the Ground : Experiences of Civil War Soldiers. Ed. Aaron Sheehan-Dean. Lexington: U of Kentucky, 2007. 135-54. Print.

Lears, T. J. Jackson. No Place of Grace : Antimodernism and the Transformation of American Culture, 1880-1920. University of Chicago Press ed. Chicago: University of Chicago Press, 1994. Print.

Lee, Spike, et al. When the Levees Broke: A Requiem in Four Acts. New York: HBO Video, 2006. DVD.

Lewis, Peirce F. New Orleans: The Making of an Urban Landscape. Placitas, NM: Center for American Places, 2011. Print. 
Libecap, Gary D., and Zeynep K. Hansen. U.S. Land Policy, Property Rights, and the Dust Bowl of the 1930s. Milano: Fondazione ENI Enrico Mattei, 2001. Print.

Lincoln, Abraham, 1809-1865. Abraham Lincoln's Speeches. New York: Dodd, Mead and Company, 1895. Print

Lindell, Michael K. "Disaster Studies." Current Sociology vol. 61, no. 5-6, 2013, pp. 797825. JSTOR. Accessed 29 March 2017.

Linderman, Gerald F. Embattled Courage : The Experience of Combat in the American Civil War. New York: Free Press, 1987. Print.

Logan, Mrs. John A. Reminiscences of a Soldier's Wife: An Autobiography. Carbondale: Southern Illinois UP, 1997. Print.

Long, Alecia. "A Notorious Attraction: Sex and Tourism in New Orleans, 1897-1917." Southern Journeys: Tourism, History, and Culture in the Modern South. Ed. Richard Starnes and Brooks Blevins.: U of Alabama, 15-41. Print.

Long, Carolyn Morrow. A New Orleans Voudou Priestess: The Legend and Reality of Marie Laveau. Gainesville: U of Florida, 2007. Print.

Long, Lisa. Rehabilitating Bodies: Health, History, and the American Civil War. University of Pennsylvania, 2004.

Lookingbill, Brad. “"A God-Forsaken Place"”: Folk Eschatology and the Dust Bowl.” Great Plains Quarterly, vol. 14, no. 4, 1994, pp. 273-286. JSTOR. Accessed 14 March 2015.

Lyon, Adelia Caroline Duncotabe. "Diary of Adelia Caroline Duncotabe Lyon, March, 1863." Reminiscences of the Civil War. Muirson \& Wright: San Jose, 1907. Print. 
"Marie Laveau, The New Orleans Queen of the Voodoos." The Daily State Journal [Richmond, Virginia] 16 Apr. 1873, Evening ed.: n.p. Chronicling America: Historic American Newspapers. Accessed 1 Feb. 2015.

Marten, James. Civil War America: Voices from the Home Front. Santa Barbara: ABCCLIO, Inc., 2003. Print.

Martin, Denise. "Ryan Murphy on the Premiere of American Horror Story: Coven and What's Next for His Witches." Vulture. New York Media, LLC, 09 Oct. 2013. Accessed 1 Mar. 2017.

---. "Ryan Murphy Talks Self-Policing, Jessica Lange's Exit, and What's Next on American Horror Story: Coven." Vulture. New York Media, LLC, 11 Dec. 2013. Accessed 1 Mar. 2017.

Mbembe, J-A, and Libby Meintjes. "Necropolitics." Public Culture vol. 15, no. 1, 2003, pp. 11-40. JSTOR. Accessed 22 Feb. 2017.

McBride, Allan, and Joseph B. Parker. "Chocolate City" Politics: Race and Empowerment in the First Post-Katrina New Orleans Mayoral Election." Politics \& Policy vol. 36, no.3, 2008, pp. 350-374. ProQuest. Accessed 09 November 2015.

McCreary, Donna. "Fashion Plate or Trendsetter?" The Mary Lincoln Enigma: Historians on America's Most Controversial First Lady. Ed. Frank J. Williams and Michael Burkhimer. Carbondale: Southern Illinois UP, 2012, pp. 186-218. Print.

McCullough, David G. Mornings on Horseback. New York: Simon and Schuster, 1981. Print. 
Mikkelson, David. "Hurricane Katrina Looters." Snopes.com. Snopes, 18 Sept. 2016. Accessed 14 Jan. 2017.

Miller, Lee M. "Controlling Disasters: Recognising Latent Goals After Hurricane Katrina.” Disasters, vol. 36, no.1, 2012, pp. 122-139. JSTOR. Accessed 25 Feb. 2016.

Molotch, Harvey. "What Do We Do with Disasters?" Sociological Inquiry, vol. 84, no.3, 2014, pp. 370-373. JSTOR. Accessed 03 March 2017.

Morse, Charles Fessenden. "Letter from Charles Fessenden Morse, March 28, 1862." Letters Written During the Civil War, 1861-1865. Privately published,1898. pp. 224. Print.

Mount Auburn, Friends Of. "Mount Auburn Consecrated." Mount Auburn. Mount Auburn Cemetery, 08 Dec. 2011. www.mountauburncemetery.org. Accessed 09 Feb. 2016.

"Mrs. Davis to Meet Mrs. Grant." Washington Bee [D.C.] 24 June 1893, News/Opinion sec. 4. America's Historical Newspapers. Accessed 29 May 2016.

"Mrs. Jefferson Davis Dead at the Majestic." New York Times. 17 Oct. 1906. New York Times (1857-1922). Accessed 11 June 2014.

"Mrs. Jefferson Davis and Kate Field, on Woman Suffrage-Woman's." The Freeman [Indianapolis] 08 Apr. 1893, News/Opinion sec. 3. America's Historical Newspapers. Accessed 11 Dec. 2015.

"Mrs. Jefferson Davis. Widow of Confederate President Lives in a Modest Way." Broad Ax [Chicago] 25 Apr. 1903, News/Opinion sec. 3. America's Historical Newspapers. Accessed 19 Nov. 2014. 
“Mrs. Lincoln." The New York Times. 18 July 1882. New York Times (1857-1922). Accessed 11 Mar. 2017.

Murphy, Ryan, et al. American Horror Story. The Complete Third Season, Coven. 2014. DVD.

Neely, Mark E., R. Gerald McMurtry. Alfred Whital Stern Collection of Lincolniana (Library of Congress). The Insanity File: The Case of Mary Todd Lincoln. Carbondale: Southern Illinois University Press, 1986. Print.

Nelson, Dana D. "Representative/Democracy: The Political Work of Countersymbolic Representation." Materializing Democracy: Toward a Revitalized Cultural Politics. Eds. Russ Castronovo and Dana Nelson. Durham: Duke UP, 2002. 21847. Print.

Nolan, Christopher, et al. Interstellar. Hollywood, California: Paramount, 2015. DVD. ---. Jonathan Nolan, and Gabriel Hardman. Interstellar: The Complete Screenplay with Selected Storyboards. 2014. Print.

Nowakowski, Kelsey. "Charts Show How Hurricane Katrina Changed New Orleans.” National Geographic. National Geographic Society, 29 Aug. 2015. Accessed 03 Mar. 2017.

The Picturesque Pocket Companion, And Visitor's Guide, Through Mount Auburn. Boston: Otis, Broaders and Company, 1839. Internet Archive, https://archive.org/details/picturesquepock00unkngoog. Accessed 09 Feb. 2016. Raban, Jonathan. Bad Land: An American Romance. 1st American ed. New York: Pantheon Books, 1996. Print. 
Rappaport, Helen. Queen Victoria: A Biographical Companion. Santa Barbara: ABCCLIO, 2003. Print.

Reid, Megan. "Social Policy, "Deservingness," and Sociotemporal Marginalization: Katrina Survivors and FEMA." Sociological Forum vol. 28, no. 4, 2013, pp. 742763. JSTOR. Accessed 11 May 2015.

Remes, Jacob A. C. Disaster Citizenship Survivors, Solidarity, and Power in the Progressive Era. Urbana: U of Illinois, 2016. Print.

Richardson, Heather Cox. West from Appomattox: The Reconstruction of America After the Civil War. New Haven: Yale University Press, 2007. Print.

Rister, Carl Coke. "Free Landhunters of the Southern Plains." Chronicles of Oklahoma, vol. 22, no. 1, 1944, pp. 392-401. http://digital.library.okstate.edu/Chronicles/index.html. Accessed 12 June 2016.

Roach, Joseph R. Cities of the Dead: Circum-Atlantic Performance. New York: Columbia UP, 1996. Print.

Roosevelt, Theodore. The Rough Riders: An Autobiography. New York: Library of America, 2004. Print.

Rozario, Kevin. The Culture of Calamity: Disaster and the Making of Modern America. Chicago: U of Chicago, 2007. Print.

Rubenstein, Diane. This Is Not a President Sense, Nonsense, and the American Political Imaginary. New York: New York UP, 2008. Print.

Shumsky, Neil Larry. "Dust, Disease, Death and Deity: Constructing and Deconstructing the "Dust Bowl"." The Journal of American Culture vol. 38, no. 3, 2015, pp. 218231. ProQuest. Accessed 05 May 2016. 
Sivulka, Juliann. Stronger Than Dirt: A Cultural History of Advertising Personal Hygiene in America, 1875-1940. Amherst, N.Y.: Humanity Books, 2001. Print. Sizoo, Joseph. "Nation Whose Science Is Bombs, Music Swing, Art Surrealism Cannot Be Great, Says Sizoo.” New York Times, 3 July 1939, pp. 15 Proquest Historical Newspapers [ProQuest]. Accessed 04 May 2015.

Slotkin, Richard. Gunfighter Nation: The Myth of the Frontier in Twentieth-Century America. New York: Atheneum, 1992. Print.

Smith, Andrew F. Starving the South: How the North Won the Civil War. New York: St. Martin's Press, 2011. Print.

Souther, J. Mark. “Making ‘America's most interesting city': Tourism and the Construction of Cultural Image in New Orleans, 1940-1984." Southern Journeys: Tourism, History, and Culture in the Modern South. Ed. Richard Starnes and Brooks Blevins. Tuscaloosa: U of Alabama, 2003. 114-137. Print.

Spear, Jennifer M. Race, Sex, and Social Order in Early New Orleans. Baltimore: Johns Hopkins UP, 2014. Print.

Stallings, Frank L. Black Sunday: The Great Dust Storm of April 14, 1935 .Austin, Tex.: Eakiess, 2001. Print.

Stegner, Wallace, and Bernard De Voto. Beyond the Hundredth Meridian : John Wesley Powell and the Second Opening of the West.New York: Penguin Books, 1992. Print.

Story, Joseph. "An Address Delivered on the Dedication of the Cemetery at Mount Auburn..." Library of Congress LCCN Permalink for 05014684. J. T. \& E. Buckingham. Accessed 09 Feb. 2016. 
Stow, Simon. "Pericles at Gettysburg and Ground Zero: Tragedy, Patriotism, and Public Mourning." American Political Science Review vol. 101, no. 2, 2007, pp. 195208. EBSCO. Accessed 03 January 2017.

Sturken, Marita. Tourists of History: Memory, Kitsch, and Consumerism from Oklahoma City to Ground Zero. Durham, NC: Duke UP, 2008. Print.

Sublette, Ned. The World That Made New Orleans: From Spanish Silver to Congo Square. Chicago, IL: Lawrence Hill, 2009. Print.

“The Sunday World's Great Christmas Number." The Evening World [New York] 11 Dec. 1902, Night ed, pp. 8. Chronicling America. http://chroniclingamerica.loc.gov. Accessed 02 Feb. 2017.

Sweet, Timothy. "Filling the Field: The Roanoke Images of John White and Theodor De Bry." A Keener Perception: Ecocritical Studies in American Art History. Tuscaloosa: University of Alabama, 2009. 23-42. Print.

Tarlock, A. Dan. "A Brief Examination of the History of the Persistent Debate about Limits to Western Growth." Hastings West-Northwest Journal of Environmental Law and Policy vol. 10, no. 2, 2004, pp. 155-168. JSTOR. Accessed 30 July 2015. "This Week's News. A Summary of Current Events.--The World's Doings for the Past Six." Washington Bee [D.C.] 30 Jan. 1892, News/Opinion sec. 1. America's Historical Newspapers. Accessed 29 May 2015.

Thomas, Lynnell L. "'Roots Run Deep Here": The Construction of Black New Orleans in Post-Katrina Tourism Narratives." American Quarterly vol. 61, no. 3, 2009. pp. 749-68. JSTOR. Accessed 1 March. 2017. 
Thompson, Anne. "'Jackie': How Pablo Larraín Looks Into the Eyes of Natalie Portman as JFK’s Widow - Video." IndieWire. Penske Business Media, LLC, 03 Dec. 2016. Accessed 19 Feb. 2017.

Tierney, Kathleen J. "From the Margins to the Mainstream? Disaster Research at the Crossroads." Annual Review of Sociology vol. 33, no. 1, 2007, pp. 503-525. ProQuest. Accessed 31 March 2017.

---. and C. Bevc. "Disaster as war: militarism and the social construction of disaster in New Orleans." Sociology of Katrina: Perspectives on a Modern Catastrophe. D.L. Brunsma, D. Overfelt and J.S. Picou, eds. Lanham, MD: Rowman \& Littlefield, pp. 35-49. Print.

Tocqueville, Alexis de. Democracy in America .New York: Knopf, 1994. Everyman's Library, no. 179. Print.

Troyer, John PhD. "Embalmed Vision." Mortality vol. 12, no. 1, 2007, pp. 22-47. JSTOR. Accessed 18 March 2013.

Turner, Frederick Jackson. The Frontier in American History. London: Penguin 2008. Print.

Urry, John. The Tourist Gaze. Ed. Jonas Larsen. London: Sage, 2011. Print.

"A Variety Of Things." Plaindealer [Detroit], News/Opinion, 07 Aug 1891. 2, America's Historical Newspapers. Accessed 05 July 2012.

Vaz, Mark C, and Christopher Nolan. Interstellar: Beyond Time and Space: Inside Christopher Nolan's Sci-Fi Epic, 2014. Print.

Villard, Henry. "Recollections of Lincoln." The Atlantic. Atlantic Media Company, 01 Feb. 1904. http://theatlantic.com. Accessed 01 Apr. 2017. 
Walter, Tony. "Modern Grief, Postmodern Grief." International Review of Sociology vol. 17, no. 1, 2007, ProQuest. 07 June 2013.

Ward, Martha. Voodoo Queen: the Spirited Lives of Marie Laveau. Jackson: U of Mississippi, 2004. Print.

Wayne, Leslie. "How Delaware Thrives as a Corporate Tax Haven." The New York Times. The New York Times, 30 June 2012. Accessed14 Mar. 2017.

Weheliye, Alexander G. Habeas Viscus: Racializing Assemblages, Biopolitics, and Black Feminist Theories of the Human. Durham: Duke UP, 2014. Print.

West, Carolyn M. "Mammy, Sapphire, and Jezebel: Historical Images of Black Women and Their Implications for Psychotherapy." Psychotherapy: Theory, Research, Practice, Training vol. 32, no. 3, 1995, pp. 458-66. Ovid. Accessed 22 Feb. 2017.

"What Happened to Gettysburg's Confederate Dead?" The Blog of Gettysburg National Military Park. National Park Service at Gettysburg, 26 July 2012. Accessed 4 Apr. 2016.

White, G E. The Eastern Establishment and the Western Experience: The West of Frederic Remington, Theodore Roosevelt, and Owen Wister. New Haven: Yale, 1968. Print.

Whitelaw, Nancy. Theodore Roosevelt Takes Charge. Morton Grove, Ill.: A. Whitman, 1992. Print.

Wiebe, Robert H. The Search for Order 1877-1920. New York: Hill and Wang, 1987. Print. 
Wilkinson, Alissa. "'Politicians Have Always Tried to Sell a Fairy Tale": Jackie's Screenwriter on the Power of a Well-crafted Image." Vox. Vox, 31 Jan. 2017. Accessed 30 Mar. 2017.

Winkle, Kenneth J. Abraham and Mary Lincoln. Carbondale: Southern Illinois University Press, 2011. Print.

Woodworth, Steven E., et al. The Chickamauga Campaign. Carbondale: Southern Illinois University Press, 2010. Print.

Worster, Donald. Dust Bowl: The Southern Plains in the 1930s. New York: Oxford University Press, 1979. Print.

Wrobel, David M. The End of American Exceptionalism: Frontier Anxiety from the Old West to the New Deal. Lawrence, Kan.: University Press of Kansas, 1993. Print.

Zeller, Bob. The Blue and Gray in Black and White : A History of Civil War Photography. Westport, Conn.: Praeger, 2005. Print.

Zinn, Howard. "Are We Politicians or Citizens?" Progressive.org. The Progressive Inc., 01 May 2007. Accessed 09 Mar. 2017. 


\section{CURRICULUM VITAE}

NAME: $\quad$ Lynda Kristian Mercer

ADDRESS: 2070 Sherwood Avenue \#1

Louisville, KY 40205

DOB: $\quad$ Versailles, Kentucky - March 2, 1979

EDUCATION

\& TRAINING:

B.A., English

University of Louisville

2002-2005

M.A., English

University of Louisville

2005-2007

$\mathrm{PhD}$, Humanities

University of Louisville

2008-2017

TEACHING: $\quad$ Instructor, 2008-2017 (present)

Humanities Department, University of Louisville

Cultures of America (43 sections)

Taught in classroom, also adapted and taught as online class

Adapted and taught as a dual-credit High School course

Adapted and taught as a concentrated course in Panama City,

Panama

Instructor, 2015

Jefferson Community and Technical College

Introduction to Humanities (1 section)

Introducing concepts of Humanities and interpretive methods

\section{SERVICE}

\& AWARDS: $\quad$ Invited Discussant, University of Louisville Green Threads

Sustainability in the Classroom Workshop 
Vice-President/Secretary, Graduate Student Council

Senator, Student Government Association

President Pro-Tempore, Arts \& Sciences Graduate Student Union

President, Association of Humanities Academics

Organizer, International Humanities Graduate Student Conference

Organizer, Humanities Graduate Student Professional Development Workshop Series

Senator, Graduate Student Council

Recipient of McDowell Creative Writing Scholarship

Editor, website designer The Raveler online student journal

Volunteer, Kentucky Women’s Book Festival

Volunteer, Forecastle Art, Music, and Activism Festival

Chair, Kentucky Philological Association Conference

Chair, The Louisville Conference on Literature and Culture

PRESENTATIONS: "A Monument to the Past: The Kentucky Derby and Louisville" 2010 Kentucky Philological Association Conference

"'Duck and Cover': The Birds and the Cold War" 2009 Popular Culture Association of the South Conference

"Burying Bodies: Literary Space for the Civil War Dead in Ambrose Bierce's Writings"

2008 South Atlantic Modern Language Association Conference

"Critical Storytelling: Walter Benjamin and Hunter S.

Thompson"

2007 Midwest Modern Language Association Conference

“'Once More Into the Breach': Shakespeare in Reconstruction Era Kentucky"

2007 Kentucky Philological Association Conference 